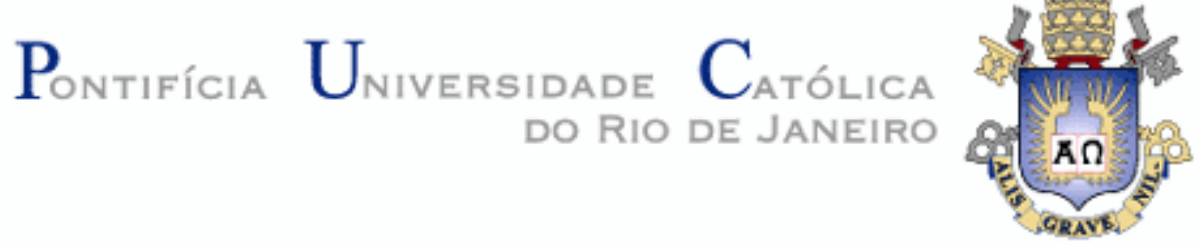

Jansen Racco Botelho de Melo

UMA QUESTÃO DE SANTIDADE O Engajamento Político-Social na vida e na teologia de Karl Barth

Dissertação de Mestrado

Dissertação apresentada ao Programa de Pós-graduação em Teologia do Centro de Teologia e Ciências Humanas da PUC-Rio como requisito parcial para obtenção do grau de Mestre em Teologia.

Orientador: Prof. Dr. Luis Correa Lima

Rio de Janeiro

Março de 2014 


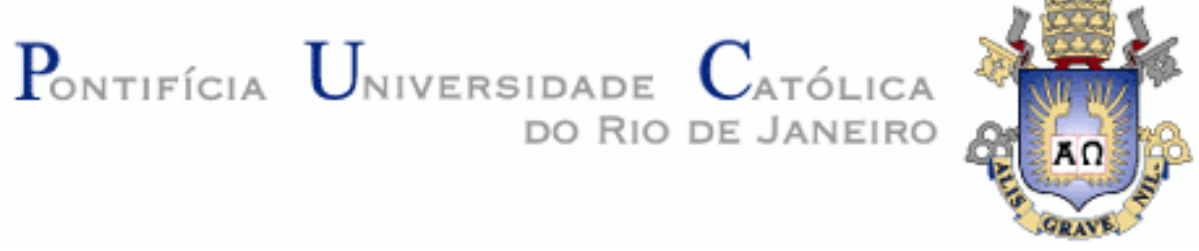

Jansen Racco Botelho de Melo

\title{
UMA QUESTÃO DE SANTIDADE \\ O Engajamento Político-Social \\ na vida e na teologia de Karl Barth
}

Dissertação apresentada como requisito parcial para obtenção do grau de Mestre pelo Programa de Pós-graduação em Teologia do Departamento de Teologia do Centro de Teologia e Ciências Humanas da PUC-Rio. Aprovada pela Comissão Examinadora abaixo assinada.

\author{
Prof. Luis Correa Lima \\ Orientador \\ Departamento de Teologia - PUC-Rio \\ Prof. Paulo Fernando Carneiro de Andrade \\ Departamento de Teologia - PUC-Rio \\ Prof. Alessandro Rodrigues Rocha \\ Unigranrio \\ Profa. Denise Berruezo Portinari \\ Coordenadora Setorial de Pós-Graduação e Pesquisa do \\ Centro de Teologia e Ciências Humanas - PUC-Rio
}

Rio de Janeiro, 25 de março de 2014 
Todos os direitos reservados. É proibida a reprodução total ou parcial do trabalho sem autorização da Universidade, do autor e do orientador.

\section{Jansen Racco Botelho de Melo}

Graduou-se em Teologia pela UMESP (Universidade Metodista de São Paulo) em 2010. Publicou um livro de história do cristianismo em 2013.

Ficha Catalográfica

\section{Melo, Jansen Racco Botelho de}

Uma questão de santidade: o engajamento político-social na vida e na teologia de Karl Barth / Jansen Racco Botelho de Melo ; orientador: Luis Correa Lima. - 2014. $108 \mathrm{f}$; $30 \mathrm{~cm}$

Dissertação (mestrado)-Pontifícia Universidade Católica do Rio de Janeiro, Departamento de Teologia, 2014. Inclui bibliografia

1. Teologia - Teses. 2. Engajamento. 3. Política. 4. Integrabilidade. 5. Santidade. 6. Justiça social. I. Lima, Luis Correa. II. Pontifícia Universidade Católica do Rio de Janeiro. Departamento de Teologia. III. Título. 
À Ana Carla, minha esposa, companheira de todos os momentos. Sem você não teria conseguido.

À Maria Linja, minha mãe, que sempre acreditou em mim. Ao Antonio Anjo, meu tio, um exemplo pra minha vida. 


\section{Agradecimentos}

Aos professores e professoras do Departamento de Teologia da PUC-Rio, por contribuírem significativamente em minha formação pastoral e teológica.

Ao meu orientador, professor Dr. Luis Corrêa Lima, por seu apoio e disponibilidade em me ajudar nesta tarefa.

Ao Marcio Simão de Vasconcellos (amigo que o Mestrado me deu), por seu companheirismo, solicitude e preciosa amizade.

Ao Dr. Alessandro Rodrigues Rocha, pelo apoio e inspiração.

À PUC-Rio e à CAPES por darem condições de trabalho que em muito facilitou na elaboração desta dissertação. 


\section{Resumo}

Melo, Jansen Racco Botelho de; Lima, Luis Correa. Uma Questão de Santidade: $O$ engajamento político-social na vida e na teologia de Karl Barth. Rio de Janeiro, 2014. 108p. Dissertação de Mestrado. Departamento de Teologia - Pontifícia Universidade Católica do Rio de Janeiro.

A vida e a teologia de Karl Barth foram marcadas pelo engajamento político-social. Engajamento este que não aconteceu simplesmente porque Barth era politizado, mas foi uma consequência de seu entendimento teológico. Para ele, a fé cristã via o homem de modo integral e não dualista, portanto não havia nenhuma esfera da vida humana que não pertencesse a Cristo. Ser engajado e lutar pelos menos favorecidos e explorados era uma consequência de fé em Jesus, era se importar com o que Jesus se importaria. Este envolvimento na vida de Barth foi visceral e o teólogo lutou pelo que cria em momentos extremos em que sua própria vida esteve em risco. A sua teologia foi toda permeada por um pensamento holístico que cria ser uma questão de santidade lutar pelos direitos humanos, pela democracia, pelos pobres. Seu exemplo e sua obra podem ser muito pertinentes, sobretudo no contexto socioeconômico da América Latina.

\section{Palavras-Chave}

Engajamento; Política; Teologia; Integralidade; Santidade; Justiça Social. 


\section{Abstract}

Melo, Jansen Racco Botelho de; Lima, Luis Correa (advisor). A Question of Holiness: the engagement in political and social in the life and theology of Karl Barth. Rio de Janeiro, 2014. 108p. MSc. Dissertation - Departamento de Teologia - Pontifícia Universidade Católica do Rio de Janeiro.

The life and theology of Karl Barth were marked by political and social engagement. This engagement didn't happen simply because Barth was politicized, but was a consequence of his theological understanding. For him, the Christian faith through the man of integral and non-dualistic mode, so there was no sphere of human life that doesn't belong to Christ. Being engaged and fight for the disadvantaged and exploited was a result of faith in Jesus, was to care what Jesus would mind. This involvement in the life of visceral and theologian Barth was fought by establishing in extreme moments when his own life was at risk. His theology was all permeated by a holistic thinking that creates holiness be a matter of fighting for human rights, democracy, the poor. His example and his work can be very relevant, especially in the socio-economic context of Latin America.

\section{Keywords}

Engagement; Policy; Theology; Integrality; Holiness; Social Justice. 


\section{Sumário}

1. Introdução 9

2. Primeira fase: Karl Barth entre 1886 - 1933

2.1. O contexto histórico entre 1886 - 1933

2.1.1. O clima de euforia e a Primeira Guerra Mundial (1886 - 1918) $\quad 17$

2.1.2. A República de Weimar (1919 - 1933) 22

2.2. A vida de Karl Barth entre $1886-1933$

2.2.1. Do nascimento à formação teológica $(1886-1911)$

2.2.2. Safenwil e início do magistério $(1911-1933)$

3. Segunda fase: Karl Barth entre $1933-1945$

3.1. O contexto político-social da Alemanha nazista (1933 - 1945) 34

3.1.1. A ascensão do Nazismo (1933 - 1939) 35

3.1.2. A Segunda Guerra Mundial (1939 - 1945) 38

3.1.3. A relação do cristianismo com o Terceiro Reich 42

3.2. Karl Barth durante o Nazismo (1933 - 1945) 52

3.2.1. Sua luta! 53

3.2.2. A Declaração de Barmen e a Igreja Confessante 62

3.2.3. A questão dos judeus 67

4. Última fase: Karl Barth entre 1945 - 1968

4.1. O contexto histórico entre 1945 - 1968

4.1.1. O mundo do Pós-Guerra $\quad 74$

4.1.2. A Guerra Fria 76

4.1.3. Novas tendências teológicas na Guerra Fria 82

4.2. Karl Barth entre $1945-1968$

4.2.1. O engajamento de Karl Barth num mundo bipolarizado 87

4.2.2. Karl Barth e o Ecumenismo 94

5. Conclusão 103

6. Referências Bibliográficas 106 


\section{1}

\section{Introdução}

Analisar a vida do teólogo suíço Karl Barth (1886 - 1968) é algo especial, ainda mais numa análise teológico-pastoral desse que foi um homem absolutamente engajado naquilo que entendeu ser expressão de sua fé no Evangelho de Jesus Cristo.

Lembro que meu primeiro contato com Barth não foi muito positivo. No início da primeira década do século XXI, estudava teologia num seminário confessional de minha denominação. Era um seminário de teor bastante conservador do ponto de vista teológico. Karl Barth, assim como muitos teólogos contemporâneos europeus, me fora apresentado por alguns professores como um teólogo liberal e subversor da fé cristã autêntica. Em princípio criei resistência em aceitá-lo e ouvia frases, supostamente de sua autoria, que denegriam a Palavra de Deus e a menosprezava. Mal sabia eu que Karl Barth foi, na verdade, o teólogo da Palavra de Deus.

No último ano do seminário conheci um professor de tendências mais liberais, este conhecia a obra de Barth e de vários outros teólogos. Ele me apresentou a célebre Carta aos Romanos, mas minha resistência em aceitar Barth como um teólogo digno de crédito continuava, até porque aquele professor não era pessoalmente dos mais simpáticos. Cerca de dois anos depois de minha formatura, fui convidado a lecionar uma disciplina chamada Teologia Contemporânea, substituindo o então professor que teve de sair do cargo, desta maneira tive de estudar a vida e obra de muitos teólogos, inclusive e especialmente Karl Barth. O livro usado pelo seminário como referência bibliográfica era de autoria de um pastor assembleiano fundamentalista e classificava todos os tidos como não-ortodoxos de hereges, e por isso tive de buscar outras fontes para poder conhecê-los melhor.

Conforme lia e pesquisava, mais me envolvia com a vida e o pensamento de Barth e assim que notei que ele não era um herege e muito menos um subversor da fé cristã como alguns me disseram, reconheci nele um profundo e cristocêntrico teólogo e percebi que a igreja protestante brasileira contemporânea, sobretudo de cunho pentecostal, precisava conhecer mais sobre o teólogo da Basiléia. 
Ao estudar a vida de Karl Barth conheci não apenas um brilhante teólogo, mas um homem de ação, que se engajou na luta pela democracia, pelos direitos humanos e pelos pobres em momentos extremamente hostis a este tipo de conduta: o período das duas Guerras Mundiais e a liderança nazista na Europa, especialmente na Alemanha onde Barth viveu.

Conhecer o Barth engajado com a política sem estar envolvido com a politicagem, lamentavelmente tão comum no contexto brasileiro, foi algo fascinante. Durante minha infância e adolescência assisti meu pai, João Botelho de Melo Filho, que foi funcionário público durante toda a sua vida, sendo candidato a vereador na cidade de Petrópolis-RJ por algumas vezes. Ele tinha muita facilidade de liderar pessoas e sempre se identificava com os menos favorecidos, até porque sua história de vida foi marcada por uma infância e adolescência de simplicidade e muito trabalho e, ao longo de sua vida teve de enfrentar muitas dificuldades sociais por ser portador de deficiência física.

Meu pai, mesmo sem possuir cargo eletivo, sempre fez o que pôde para ajudar os mais necessitados, foi um homem que sempre conheceu a classe política da cidade e preferiu uma vida modesta a vender seus ideais de vida e de consciência. Cresci vendo este exemplo de meu pai e, quando faleceu em 2003 prometi a mim mesmo que seria candidato a vereador como ele sempre quis. Candidatei-me nas eleições municipais de 2004 com apenas 22 anos de idade, naquela oportunidade tive cerca de quinhentos votos, mas obtive uma vitória de consciência e anos mais tarde descobri que através do ministério pastoral poderia fazer muito mais que se fosse titular de algum cargo eletivo.

No ministério assisti a cenas que me fizeram crer que aquele não poderia ser o envolvimento mais correto que a igreja deveria ter: denominações tendo candidatos próprios e praticamente forçando os seus membros a votarem naqueles nomes, um verdadeiro atentado contra a democracia. Igrejas preocupadas em eleger seus representantes, não porque eles lutariam pelos ideais cristãos de justiça social, emprego, educação, saúde pública e outros valores do tipo, mas estes lutariam pelos interesses da própria denominação pelas quais foram eleitos. Não conseguia crer que aquilo seria o engajamento político-social adequado, ao mesmo tempo em que continuava crendo que os cristãos não podiam simplesmente ignorar os temas político-sociais do país. 
Conhecer a Teologia da Libertação e a Teologia da Missão Integral foi para mim como quem encontra uma ilha em meio ao oceano e, descobrir o exemplo de engajamento político-social de Karl Barth foi uma experiência iluminadora e libertadora. Barth nunca possuiu um cargo público, nunca fez campanha eleitoral para si ou para quem quer que fosse, nunca rifou o púlpito de sua igreja para defender os interesses de uma minoria já privilegiada e, mesmo diante disso tudo, lutou contra os interesses de empresários ricos e poderosos que deixavam os trabalhadores de Safenwill cada vez mais pobres, lutou pelos direitos das mulheres que também trabalhavam e tinham condições ainda piores.

Karl Barth na década de 30 foi um dos primeiros a perceber a ameaça que o nazismo de Adolf Hitler representava para a Alemanha e para todo o mundo, ameaça que infelizmente se concretizou anos mais tarde. Barth se negou a fazer parte dos cristãos da Alemanha, que apoiaram o regime nazista e reconheceram Hitler como o Füher da igreja. Barth ingressou na Igreja Confessional, foi um dos autores da Declaração de Barmen e um dos principais nomes na luta em prol da democracia.

Barth não se calou durante a Segunda Guerra Mundial e nem depois dela baixou a guarda, engajou-se no movimento ecumênico e sempre que entendeu necessário se posicionou em relação à bipartição do mundo entre capitalistas e comunistas.

O contexto religioso do qual vim era dualista e contraditório. Dualista porque sempre apelava para a constante batalha entre mundo x igreja, entre carne $\mathrm{x}$ espírito, entre sociedade mundana $\mathrm{x}$ ambiente sagrado representado pela igreja, etc... Para os principais defensores desse dualismo, política era algo perverso a qual os crentes deveriam manter a mais absoluta distância, era algo que não deveria provocar nenhum tipo de interesse nos crentes, e naquele contexto não provocava mesmo!

Por outro lado, tinha aqueles que se aproveitaram dessa cultura, e começaram a mudar o foco da discussão, criaram jargões do tipo: cristão vota em cristão, que era um apelo para moralizar a política partidária do país, e só havia uma maneira segundo aquele discurso: colocar homens de Deus naquele antro de corrupção. A contradição residia no fato de que a preocupação não era com os pobres, nem com os pobres da própria igreja, mas a preocupação era com a defesa dos interesses bem particulares das diversas denominações. 
Karl Barth tem muito a nos dizer e a nos inspirar para um modelo digno, cidadão e cristão de engajamento político-social, que faça política e não politicagem, que seja abnegado e preocupado apenas com os que realmente são desfavorecidos, que lute pela democracia, por acesso ao emprego, educação e saúde a todos e que tenha Cristo como o centro de sua vida e de sua obra e, assim se preocupe com o que Cristo se preocuparia. 


\section{2}

\section{Primeira fase: Karl Barth entre 1886 - 1933}

$\mathrm{O}$ ano de 1886 foi marcado por grandes acontecimentos e dos mais variados: neste ano foi realizado o primeiro campeonato mundial de xadrez, o primeiro automóvel foi construído, a estátua da Liberdade foi inaugurada em Nova Iorque e a Coca Cola foi vendida pela primeira vez nos Estados Unidos ${ }^{1}$. Neste agitado ano de 1886, mais precisamente às 5 horas da manhã do dia 10 de maio $^{2}$, nasceu na cidade suíça da Basiléia na Rua Grellinger 42, o que viria a ser considerado um dos mais importantes teólogos da história do cristianismo, Karl Barth.

A família de Barth tradicionalmente tinha muitos pastores e pessoas envolvidas com a fé protestante. Barth era filho de Friedrich (Fritz) Barth (1856 1912), um professor de Novo Testamento ligado à Igreja Reformada da Suíça e de Anna Sartorius.

Friedrich Barth foi um pensador que se distanciou do liberalismo teológico e procurou se posicionar como um teólogo conservador $^{3}$, o que evidentemente influenciaria seu filho. Friedrich Barth escreveu um respeitável livro sobre a vida de Jesus ${ }^{4}$. Quando Karl tinha apenas três anos de idade, seu pai foi convocado para assumir as cátedras de Novo Testamento e de História da Igreja na Universidade de Berna, um importante centro acadêmico da Suíça, naquela ocasião.

A infância e a adolescência de Karl Barth foram em Berna, em virtude do trabalho do pai. É neste período que Karl Barth tem seu primeiro despertamento para estudar teologia enquanto era aluno da classe de confirmação batismal com o pastor Robert Aeschbacher, da Igreja Reformada Suíça ${ }^{5}$. Barth tinha quinze anos de idade quando assistiu às aulas do entusiasmado pastor. Suas aulas eram tão envolventes que muitos jovens se sentiam atraídos a participarem de suas lições de teologia.

${ }^{1}$ SCHULER, Roberto, Prefácio in: BARTH, Karl, Revelação de Deus como Sublimação da Religião. São Paulo: Fonte Editorial, 2011. p.9.

${ }^{2}$ Idem.

${ }^{3}$ FILHO, Manoel Bernardino de Santana. Palavra-Evento e Práxis Libertadora. Tese Doutoral, PUC-Rio, 2012. p. 42.

${ }^{4}$ MACKINTOSH, Hugh R. Teologia Moderna - De Schleiermacher a Bultmann. São Paulo: Fonte Editorial, 2002. p. 288.

${ }^{5}$ FILHO, Manoel Bernardino de Santana. o.c. p. 42. 
As aulas iniciais foram tão importantes na vida de Karl Barth que dois anos mais tarde, quando tinha dezoito anos de idade em 1904, decidiu que estudaria teologia na Universidade de Berna, onde mesmo contra a vontade de seu pai, tornou-se um simpatizante da teologia liberal ${ }^{6}$.

A formação teológica de Karl Barth começou na Universidade de Berna na Suíça, passou por Berlim, Marburgo e terminou em Tubingen, ambos na Alemanha. Barth concluiu sua graduação em teologia em 1909. Nos dois últimos anos de sua formação, Barth já era secretário de redação da Revista Christliche Welt ${ }^{7}$.

Em 1909 Barth foi para Genebra na Suíça para ser pastor auxiliar da paróquia suíça-alemã, lá permaneceu por quase dois anos, cumprindo as exigências práticas para receber sua ordenação como Ministro da Palavra Divina e se tornar oficialmente pastor da Igreja Reformada Suíça ${ }^{8}$. Depois desses dois anos experimentais, Barth recebeu o convite para assumir a paróquia de Safenwill na pequena cidade de Aargau na Suíça, experiência esta que transformou sua vida e sua teologia. A experiência de dez anos à frente da comunidade de Safenwil (1911 - 1921) foi uma experiência que mudaria sua história e que o ajudaria imensamente na maturação de seu pensamento e práxis pastoral.

Como o pastor daquela pequena comunidade operária, Barth se deparou com um povo simples e trabalhador que frequentemente era explorado pela elite dominante daquela sociedade. Também se deparou com algo pelo qual não esperava: a insuficiência do método e da pregação liberal diante de uma comunidade simples, que o próprio Barth percebeu que apenas queria ouvir a Palavra de Deus. Barth observou o quão distante estavam os postulados científicos que recebera em sua formação da vida real das pessoas com as quais ele precisava trabalhar no dia-dia.

Foi uma década muito produtiva em sua vida, apesar de ter perdido seu pai, Friedrich Barth em 1912, que o havia influenciado decisivamente em seu crescimento ministerial e pessoal. Por outro lado, também neste período de pastoreio em Safenwil, Barth viveu momentos muito felizes como o seu

\footnotetext{
${ }^{6}$ SCHULER, Roberto, Prefácio in: BARTH, Karl, Revelação de Deus como Sublimação da Religião, p. 10.

${ }^{7}$ Christliche Welt significa Mundo Cristão.

${ }^{8}$ SCHULER, Roberto, Prefácio in: BARTH, Karl, Revelação de Deus como Sublimação da Religião, p. 10.
} 
casamento com Nelly Hoffman (1893 - 1978) em 1913. Nelly foi sua companheira até o fim de sua vida e lhe deu cinco filhos, quatro dos quais nasceram enquanto Barth era pastor em Safenwil: sua primogênita Franciska, nasceu em 1913, seu filho Markus, nasceu um ano depois, Christoph nasceu em 1917 e Matthias que nasceu no ano de 1921.

Diante da incapacidade do método liberal em comunicar a Palavra de Deus às pessoas simples de sua comunidade e diante do quadro de desapontamento gerado pela Primeira Guerra Mundial (1914 - 1918) na euforia progressista que tomou conta da Europa no final do século XIX e início do século XX, Barth se distanciou do Liberalismo Teológico e em 1919 lançou a primeira versão de sua Carta aos Romanos. A publicação desta obra foi um marco da teologia do século XX e representou uma eficaz reação ao Liberalismo Teológico.

Conviver e pastorear pessoas simples influenciou diretamente o pensamento e a obra de Barth, com isso, ele percebeu que a teologia não era um mero trabalho de intelectuais num escritório, mas que era feita pela própria comunidade de fé.

Em 1921 Barth se mudou de Safenwil em virtude de um convite que recebeu para ser professor de teologia reformada em Gottingem, na Alemanha. Deu início a um novo momento na sua vida e carreira: o seu trabalho docente. Entre os anos de 1921 a 1933, sua vida foi marcada por uma grande produtividade teológica, por conta disso, Barth recebeu o seu primeiro doutorado honoris causa, pela Universidade de Munique em 1922, logo após o lançamento da segunda edição de sua Carta aos Romanos.

Barth criou duas revistas teológicas, uma em 1923 chamada Zwischen den Zeiten $^{9}$ e a sua substituta, já em 1933, Theologische Existenz Heute ${ }^{10}$. Entre 1925 e 1929, Karl Barth se tornou catedrático de Dogmática e Teologia do Novo Testamento em Munique e neste período, sua teologia começou a ficar cada vez mais clara e original, embora ainda continuasse usando a filosofia existencialista de Soren Kierkegaard $\left(1813\right.$ - 1855) para expor a mensagem cristã ${ }^{11}$. Em 1932, Barth retomou seu trabalho desde o início para tentar tirar o existencialismo de sua obra.

\footnotetext{
${ }^{9}$ Zwischen den Zeiten significa Entre os Tempos.

${ }^{10}$ Theologische Existenz Heute significa Existência Teológica Hoje.

${ }^{11}$ MONDIN, Battista. Os Grandes Teólogos do Século XX. São Paulo: Editora Teológica, 2003. p. 39.
} 
No ano de 1925, nasceu seu quinto e último filho, Hans Jacob. Em 1930 recebeu o segundo doutorado honoris causa, desta vez pela Universidade de Glasgow, Escócia. Ainda em 1930, Barth assumiu a cátedra de Teologia Sistemática na Universidade de Bonn e tornou-se professor honorário na Hungria.

No ano seguinte em 1931, publicou o seu Fides Quaerens Intellectum ${ }^{12}$, baseado na obra teológica de Santo Anselmo da Cantuária (1033 - 1109).

Entre 1886 e 1933 houve grandes acontecimentos mundiais que marcaram não apenas a vida de Barth, mas como toda a humanidade. Estes episódios serão expostos a seguir.

\section{1}

\section{O contexto histórico entre 1886-1933}

O século XVI assistiu ao movimento conhecido como Reforma Protestante, um cisma que se deu na Igreja Ocidental e que separou, definitivamente, católicos e os chamados protestantes. A Reforma data de 1517, ano em que o monge agostiniano Martinho Lutero (1483 - 1546) teria afixado as 95 teses na porta da catedral de Wittemberg na Alemanha dando início a um processo que culminou na separação entre ambos.

Cerca de cem anos depois das teses, em 1618 desatou a Guerra dos Trinta Anos (1618 - 1648), uma série de conflitos gerados pela intolerância religiosa tanto de católicos quanto de protestantes. O resultado foi lastimável: milhares de mortos e regiões do norte da Europa praticamente devastadas. Tudo aquilo gerou um sentimento bastante antirreligioso no continente, até que o filósofo René Descartes (1596 - 1650) propôs a razão, algo comum entre católicos e protestantes, como o parâmetro de julgamento de todas as verdades, verdades estas que só seriam aceitas como tais depois de passarem por um criterioso exame racional, independente das opiniões do papa e da bíblia. A razão passou a ser uma espécie de autoridade final. Era o início da secularização. A religião não mais controlava a sociedade, agora ela era apenas uma esfera da vida social.

Os séculos XVII e XVIII foram os séculos do racionalismo, do empirismo e do iluminismo. Período em que a razão humana foi enaltecida e reverenciada como o meio mais seguro para se chegar ao conhecimento da verdade. A religião

\footnotetext{
${ }^{12}$ Obra traduzida em português como Fé em Busca de Compreensão.
} 
foi considerada algo de um passado retrógrado, de um tempo em que, nas palavras de Immanuel Kant (1724 - 1804), o mundo ainda não tinha alcançado a maioridade e, portanto, precisava ser conduzido pela religião, o que deixara de ser necessário. A razão foi quase que verdadeiramente adorada como no emblemático episódio da Revolução Francesa (1789) em que uma atriz foi entronizada como deusa da razão na catedral de Notre Dame ${ }^{13}$. A Revolução Francesa, que foi uma revolução iluminista, impôs um duro golpe ao catolicismo francês e à religião europeia em geral.

No final do século XVIII aconteceu a Revolução Industrial na Inglaterra e a partir de então, o ser humano começou a ser substituído pelas máquinas no processo industrial. Esta Revolução foi um marco dos ideais progressistas que aos poucos tomava conta daquele contexto. Com o desenvolvimento do maquinário, a produção foi barateada e acelerada, gerando um grande aumento na produção, uma diminuição dos custos para os patrões e um alto preço social que gerou uma massa de excluídos do processo consumista. O lucro passou a ser a mola mestra nas relações trabalhistas e o ser humano começou a olhar para o futuro e deixar o passado literalmente para trás.

\subsection{1 \\ O clima de euforia e a Primeira Guerra Mundial (1886 - 1918)}

O pensamento moderno não foi bem aceito pela religião. Ambos travaram brigas hercúleas. Além da Revolução Francesa, da Revolução Industrial, poderíamos citar a Revolução Americana, onde o anglicanismo e o metodismo foram vistos como adversários a serem superados, uma vez que defendiam a permanência das Treze Colônias junto à Inglaterra.

Neste processo, o Papa Pio IX $\left(1846\right.$ - 1878) ${ }^{14}$ escreveu o seu famoso Syllabus, no qual o pontífice condenou 80 males da modernidade que deveriam ser combatidos pela igreja ${ }^{15}$.

${ }^{13}$ CAIRNS, Earle. O Cristianismo através dos séculos. 2ed. São Paulo: Editora Vida Nova, 1995. p. 334.

${ }^{14}$ Data do respectivo pontificado. Em todos os papas que serão citados neste trabalho as datas entre parênteses referem-se à duração de seus respectivos pontificados.

${ }^{15}$ GONZALEZ, Justo L. Uma história ilustrada do cristianismo, vol. 9 A era dos novos horizontes. São Paulo: Editora Vida Nova,1998. p. 110. 
O clima de euforia com o progresso tomava conta de todas as esferas da sociedade europeia. Neste período surgiram o Positivismo de Augusto Comte (1798 - 1857), que explicava a evolução do pensamento humano partindo do teológico para o metafísico e por fim para o científico. O Positivismo e seu ideal progressista influenciou a Proclamação da República no Brasil em 1889, com o seu lema na bandeira republicana Ordem e Progresso. Surgiu a Teoria da Evolução de Charles Darwin (1809 - 1882), que procurava explicar o desenvolvimento humano de modo progressista (evolucionista). Além da psicanálise de Sigmund Freud (1856 - 1939).

O século XIX deu provas muito convincentes de que os ideais da razão estavam corretos. A busca pelo progresso e pelo futuro causou uma grande euforia e eram por si mesmos, provas incontestáveis da capacidade humana. A Europa vivia um momento mágico: como o renomado historiador Eric Hobsbawm (1917 - 2012) afirma que em boa parte deste período não houve na Europa guerra alguma em que exércitos de grandes potências cruzassem alguma fronteira hostil $^{16}$. Além disso, a euforia criada com o avanço do progresso era sem precedentes: os países prosperavam, a tecnologia era desenvolvida como nunca antes e as democracias europeias estavam consolidadas.

O impacto da razão e dos ideais que a mesma trouxe de progresso foram tão profundos que a Europa se convencera de que não precisava mais da religião e de que esta era coisa do passado. Até mesmo a teologia embarcou no navio do progresso e produziu no campo protestante o Liberalismo Teológico, uma espécie de casamento entre a teologia e a filosofia kantiana. Era a racionalização da teologia, uma aposta no progresso científico daquele contexto, desta vez aplicada ao pensar teológico.

Já no campo católico os posicionamentos em relação às pesquisas históricas e bíblicas foram diferentes: o Papa Leão XIII (1878 - 1903) deu abertura para os estudiosos aprofundarem as pesquisas na área bíblica, além de ter aberto os arquivos do Vaticano para pesquisas historiográficas. O pontificado seguinte ao de Leão XIII seguiu uma linha mais conservadora e o Papa Pio X (1903 - 1914) chegou a condenar os católicos que embarcaram em tais pesquisas.

${ }^{16}$ HOBSBAWM, Eric. Era dos Extremos, o breve século XX 1914 - 1991. 2ed. São Paulo: Editora Companhia das Letras, 2012. p. 30. 
Para muitos pensadores, o século XIX representou a maturidade do mundo. O mundo havia progredido, ou seja, tinha se libertado de todas as suas tutelas, dentre as quais a religião era a principal. Friedrich Schleiermacher $(1768$ - 1834), que deixou marcas no pensamento de Barth, é considerado o pai do Liberalismo Teológico. Ele foi o primeiro a produzir uma teologia partindo dos postulados kantianos $^{17}$.

O Liberalismo Teológico pretendeu modernizar a teologia protestante e recusou aceitar a fé religiosa apenas com base na autoridade ${ }^{18}$. Deus e o mundo eram vistos de modo inseparáveis e, aos poucos, o cristianismo vai abrindo mão de doutrinas consideradas essenciais como a doutrina do pecado, a salvação pela fé em Jesus Cristo, etc. Assim como em todas as áreas da vida europeia do século XIX, o método Liberal, encharcado do ideal progressista, despontava como infalível. A ênfase colocada no potencial racional do homem parecia ser mesmo o auge na história do pensamento.

Como falado, o clima que tomou conta do século XIX foi de intensa euforia. Parecia que nada conseguiria deter o avanço progressista europeu, as nações estavam cada vez mais ricas e poderosas, e assim avançavam dominando nações de outras regiões periféricas do globo. A industrialização e a tecnologia prosseguiam a todo vapor.

No século XIX houve uma rápida expansão do capitalismo por toda a Europa. Este capitalismo era fundamentado pela doutrina do Liberalismo Econômico, que exaltava o direito de propriedade individual e a riqueza, opondose à intervenção do Estado na economia ${ }^{19}$. Esse espírito liberal, inspirado nos ideais filosóficos iluministas da Revolução Francesa, também acreditava no progresso, como fenômeno natural e decorrente da livre-concorrência que dava fôlego às atividades econômicas e gerava no fim do processo, a felicidade e a prosperidade de $\operatorname{todos}^{20}$.

${ }^{17}$ MONDIN, Battista. o.c. p. 24.

${ }^{18}$ HORDERN, William E. Teologia Contemporânea. São Paulo: Editora Hagnos, 2003. p. 101.

19 AQUINO, Rubim de; RESENDE, Clymene; FRANCO, Denise e LOPES, Oscar. História das Sociedades. 35ed. Rio de Janeiro: Editora ao Livro Técnico,1995. p. 230.

${ }^{20}$ Idem. 
Entre o fim do século XIX e o início do século XX, a Europa viveu o que fora chamado de Belle Époque (1899 - 1914) um período próspero e incrivelmente atraente para quem tinha dinheiro ${ }^{21}$.

Mesmo diante do clima eufórico do século XIX, alguns não se convenciam de que o progresso era mesmo a realização de um sonho, algumas áreas da sociedade olhavam desconfiadamente para todo aquele clima, por exemplo, o filósofo dinamarquês Soren Kierkegaard já denunciava a tendência de coisificação do ser humano, como se o individuo fosse apenas uma peça descartável no mecanismo social ${ }^{22}$.

O Papa Leão XIII lançou sua famosa encíclica Rerum Novarum em 1891. $\mathrm{Na}$ encíclica, o papa estabeleceu a doutrina social da igreja reconhecendo a gravidade da questão social surgida depois do capitalismo. Leão defendeu salários e jornada de trabalho que fossem justos, além de criticar os patrões que exploravam os empregados. A encíclica de Leão XIII motivou a criação de vários sindicatos pela Europa.

Sem dúvida, a maior expressão de contrariedade ao modelo progressista e capitalista europeu foi o chamado Socialismo Científico, idealizado pelas obras dos alemães Karl Marx (1818 - 1883) e Friedrich Engels (1820 - 1895), dentre as quais se destaca $O$ Manifesto do Partido Comunista. Os idealizadores se opunham vorazmente ao capitalismo e defendiam o governo do proletariado e o fim da luta de classes.

Mesmo a grande maioria dos europeus que não deu ouvidos aos alertas sobre os perigos gerados pelo progressismo, assistiu as consequências deste processo. Com o avanço imperialista das potências europeias que dominavam as demais nações, os possíveis choques entre elas foram ficando cada vez mais inevitáveis. Países que tiveram um desenvolvimento tardio revindicavam uma redistribuição de territórios. A que mais lutou por isso foi a Alemanha, onde Barth viveu boa parte de sua vida.

A luta por mercados consumidores e por áreas de investimentos gerou vários pontos de atrito entre as potências europeias. Só a Alemanha teve três pontos de atrito delicados, um com a Inglaterra, acirrado pela corrida navalista,

${ }^{21}$ HOBSBAWM, Eric. A Era dos Impérios 1875-1914. 13ed. São Paulo: Editora Paz e Terra, 2011. p. 426.

${ }^{22}$ HORDERN, William E. o.c. p. 147. 
pois, embora a Alemanha não tivesse colônias, o país estava empreendendo alta tecnologia na indústria naval e já desbancava a rival Inglaterra. O segundo ponto de atrito foi com a França por causa da região da Alsácia-Lorena, território francês que foi anexado pela Alemanha em 1871. Além disso, a Alemanha era contrária às intenções francesas no Marrocos. O terceiro ponto de atrito foi com a Rússia, disputa gerada em torno do domínio do Estreito de Dardanelos, uma importante rota comercial que criava choques de interesses entre alemães e $\operatorname{russos}^{23}$.

A situação foi ficando cada vez mais insustentável quando, em 1914, o arquiduque do Império Austro-Húngaro e herdeiro do trono, Francisco Ferdinando (1863 - 1914) foi assassinado por um extremista sérvio quando visitava Sarajevo ocupada pelos austríacos. Imediatamente a este evento, a Alemanha deu total apoio ao Império Austro-Húngaro seu aliado e, os russos tomaram partido dos sérvios.

No mesmo ano de 1914 a Europa estava em guerra. Por essa o século XIX não esperava! O progresso que era tão reverenciado antes, deu a sua versão mais destrutiva: ele também servia para matar! Todo o desenvolvimento e progresso de antes é o que vai financiar a I Guerra Mundial. Todo aquele clima de euforia se transformou numa profunda decepção, o progresso e a esperança depositados na razão humana acabaram gerando uma guerra de proporções mundiais. O historiador Eric Hobsbawn nos diz que o acúmulo de armamento acelerou o processo bélico na Europa ${ }^{24}$.

A humanidade ficou estupefata com o que o ser humano foi capaz de produzir e o clima passou a ser de grande decepção. De um lado a Tríplice Aliança formada por Alemanha, Império Austro-Húngaro e Itália, de outro lado, a Tríplice Entente, com Rússia, Inglaterra e França. A guerra teve três fases principais: na primeira fase em 1914, foi chamada de Guerra de Movimento, marcada pela ofensiva alemã na frente ocidental. A segunda fase da Guerra foi entre 1915 e 1916 e foi chamada de Guerra de Trincheiras e, em 1917 aconteceu a terceira e última fase da guerra quando a Rússia fez a sua revolução socialista, e se retirou dos conflitos, dando lugar à atuação decisiva dos Estados Unidos. 239.

${ }^{23}$ AQUINO, Rubim de, RESENDE, Clymene, FRANCO, Denise e LOPES, Oscar. o.c. p.

${ }^{24}$ HOBSBAWM, Eric. A Era dos Impérios 1875-1914. p. 474. 
Foram quatro anos de guerra (1914 - 1918), milhões de mortos, países devastados pelos efeitos dos conflitos e muita frustração.

A frustração também abalou o Liberalismo Teológico, primeiro porque ele foi uma adaptação da teologia à euforia com a razão humana, segundo porque vários teólogos liberais praticamente não se opuseram as ameaças de guerra e permaneceram quase que imóveis aos acontecimentos que levaram aos conflitos.

Em 1919 foi feita em Paris uma conferência de paz que contou com 32 países aliados e neutros, deixando de fora a Rússia (aquela altura, comunista) e os países derrotados, o objetivo era impor sanções aos países vencidos, especialmente a Alemanha ${ }^{25}$. Com os tratados do pós-guerra, a Alemanha foi duramente humilhada e a guerra ainda não tinha verdadeiramente terminado. $\mathrm{O}$ Papa Bento XV (1914 - 1922) conhecido como o papa da paz, por sua luta para que a I Guerra Mundial não acontecesse, tentou alertar às potências de que humilhar os alemães geraria ainda mais ódio e insatisfações, mas não foi ouvido.

Os resultados do Tratado de Versalhes de 1919 foram duros demais contra a Alemanha: impunha que o país tivesse que se desmilitarizar, devolver os territórios anexados de nações vizinhas, especialmente a região da Alsácia-Lorena à França e pagar indenizações aos países afetados pela guerra. Além disso, o Tratado reconhecia a independência da Polônia e da Tchecoslováquia proibindoas de se unir a Áustria ${ }^{26}$.

\subsection{2}

\section{A República de Weimar (1919-1933)}

O mundo entre 1919 e 1933 viveu o chamado período entre-guerras, um momento de reorganização da ordem política internacional. Neste período a economia da Alemanha se agravou cada vez mais até entrar em colapso e, o orgulho nacional continuava criticamente ferido.

Em 1919, logo após o teórico desfecho da Primeira Guerra Mundial, a Alemanha estabeleceu a chamada República de Weimar entre os anos de 1919 1933, em substituição ao Império Germânico, o Segundo Reich, formado depois da reunificação alemã de Otto Von Bismarck (1815 - 1898). 244 .

${ }^{25}$ AQUINO, Rubim de, RESENDE, Clymene, FRANCO, Denise e LOPES, Oscar. o.c. p.

${ }^{26}$ Ibid, p. 246. 
A República de Weimar recebeu este nome por ser um modelo republicano proclamado na cidade de mesmo nome. Era um sistema de governo parlamentarista, onde o presidente da república nomeava um chanceler que seria o responsável pelo Poder Executivo, enquanto que o Poder Legislativo era constituído no parlamento chamado de Reichstag. Curiosamente, este novo sistema de governo abriu caminho para a ascensão política de Adolf Hitler (1889 - 1945) na Alemanha.

Esse sistema republicano só foi proclamado na Alemanha porque o antigo imperador Wilhem II (1859 - 1941) teve de abdicar do trono em virtude dos fatos que se seguiram à Primeira Guerra. Foi também um período marcado por um enorme saudosismo, já que a época posterior a Reunificação Alemã fora um período de grande avanço e prosperidade, em que o país se tornou uma potência em pouco tempo e, no período de Weimar, o país vinha sofrendo constantes humilhações como consequência da Guerra.

Por causa da terrível situação econômica alemã, a República de Weimar teve de optar por cortes econômicos e sociais, e o desemprego ganhou proporções catastróficas. Com isso, a República se enfraqueceu em muito e, nas eleições de 1932, os nacionais-socialistas (nazistas) e comunistas conseguiram alcançar a maioria dos votos alemães ${ }^{27}$.

O último presidente da República de Weimar foi Paul von Hindenburg (1847 - 1934). E este era um ferrenho opositor de Hitler e havia resistido a várias tentativas de Hitler se tornar o chanceler. Em 1932, mesmo com a saúde debilitada concorreu novamente à presidência para evitar a eleição de Hitler, mas com o enfraquecimento do sistema político da República de Weimar, teve de nomeá-lo chanceler em janeiro de 1933, mesmo contra a sua vontade.

Neste ínterim, houve a Revolução Socialista na Rússia em 1917 e a implantação da Ditadura Comunista no país criando a União das Repúblicas Socialistas Soviéticas (URSS). O movimento liderado por Vladmir Iliich Ulianov (Lênin) (1870 - 1924) derrubou o regime do então Czar Nicolau II (1868 - 1918).

Outro momento marcante do período foi a quebra da bolsa de Nova Iorque em 1929. O mundo iludido com o progresso e o avanço do capitalismo teve de encarar a dura realidade de que tudo não era tão perfeito quanto parecia. Essa crise

${ }^{27}$ HOBSBAWM, Eric. A Era dos Extremos 1914 - 1991. p. 139. 
foi gerada pela própria Primeira Guerra Mundial, onde os Estados Unidos começaram a lucrar muito com os efeitos da guerra para a Europa, sendo assim o país teve um acúmulo ocasionado pela superprodução, perto do fim da década de 20, pois, conforme as economias europeias ganhavam fôlego deixavam de comprar dos Estados Unidos, que sem ter para quem vender, quebrou. O Estado precisou intervir. Era mais um golpe na euforia gerada pelo modelo liberal.

\section{2}

\section{A vida de Karl Barth entre 1886 - 1933}

A infância e adolescência de Karl Barth foram vividas durante o período de euforia mundial com o progresso e o desenvolvimento. Não apenas estas tenras etapas de sua vida como também a sua formação teológica aconteceu dentro deste período. Com toda a certeza, Barth se deparou com professores e pensadores que embarcaram nos ideais progressistas e foi aluno de importantes teólogos liberais.

De uma família religiosa, Barth foi criado num ambiente bastante propício ao desenvolvimento da fé cristã. Enquanto se formava em teologia, recebeu um conteúdo rico e variado e, por insistência de seu pai, que não se tornou um teólogo liberal mesmo naquele momento, Barth estudou até mesmo em instituições de teologia conservadora.

Barth foi um homem de seu tempo. Foi influenciado por ícones liberais e durante alguns anos acreditou que o método liberal de se pensar teologia fosse o ideal. Foi a vida real que fez Barth repensar e refazer a sua teologia.

Assumiu a comunidade de Safenwil em 1911 e ao trabalhar com pessoas simples e trabalhadoras percebeu a incapacidade do método liberal em comunicarlhes a Palavra de Deus. Barth buscou conselho com expoentes liberais de seu tempo, mas só encontrou o que necessitava ao se voltar para as páginas da Bíblia. Percebeu que a teologia era exercício da comunidade e não da academia e os estragos da Primeira Guerra Mundial o levou à uma desilusão com o antigo método por ele adotado.

Um ano após a guerra lançou a primeira versão de sua Carta aos Romanos. Ainda em meio ao seu pastoreio em Safenwil já despontava como teólogo e o que ele produzia teologicamente nunca foi divorciado com seu engajamento políticosocial e, nem vice-versa. 
Em Safenwil dedicou-se a incansável luta em favor dos mais pobres e dos explorados pelo sistema opressor de sua cidade e quando aceitou o convite para ser professor em Gotingen em 1921 deu início a uma profunda e brilhante carreira como professor. $\mathrm{Na}$ academia, Barth continuou seu engajamento político-social e nutriu seu pensamento de uma teologia eclesiástica. Deu início a sua Dogmática Eclesiástica e sempre exortou os seus alunos a estarem atentos ao seu contexto político-social e a fazerem teologia encarnada com a vida humana. A desilusão liberal fez Barth se voltar para a Bíblia e para a vida humana.

\subsection{1}

\section{Do nascimento à formação teológica (1886 - 1911)}

O pai de Karl Barth, Friedrich Barth foi muito influenciado pelo teólogo pietista Johann Tobias Beck $\left(1804\right.$ - 1878) da Universidade de Tubingen ${ }^{28}$. A influência pietista pôde ser vista no pensamento de Friedrich Barth e na obra do próprio Karl Barth, pois graças ao pietismo, o conceito de experiência foi mais valorizado que a doutrina por si mesma ${ }^{29}$. A influência pietista já tinha feito o pai do metodismo, John Wesley (1703 - 1791) incluir a experiência em seu chamado Quadrilátero Wesleyano. O pietismo também influenciou o pai do liberalismo alemão, Friedrich Schleiermacher, que simpatizava com seu estilo de vida cristã e sua paixão por Jesus. E na família Barth (tanto no pai quanto no filho) a marca pietista esteve presente.

O Pietismo apresentava traços negativos segundo Friedrich Barth, como a tendência anti-intelectual, sectária e legalista do movimento. Porém, havia no Pietismo quatro características que lhe soavam muito saudáveis: a) a prioridade da vida sobre a doutrina; b) a necessidade do novo nascimento; c) ligação entre justificação e santificação; d) a vinda do Reino de Deus ${ }^{30}$.

Quando completou vinte anos de idade, Barth que começou seus estudos na Universidade da Berna se transferiu para a Universidade de Berlim, na Alemanha, onde conheceu e foi aluno de um dos principais representante da teologia liberal, Adolf von Harnack (1851 - 1930). Num dos seminários ministrados pelo professor Harnack, Karl Barth apresentou um trabalho de 158 páginas sobre a

\footnotetext{
${ }^{28}$ FILHO, Manoel Bernardino de Santana. o.c. p. 42.

${ }^{29}$ Idem.

${ }^{30}$ Idem.
} 
obra missionária do apóstolo Paulo no livro de Atos dos Apóstolos, ganhou uma pequena correção de seu professor, mas Harnack percebeu que estava diante de um promissor teólogo ${ }^{31}$. Barth não apenas se impressionou com a capacidade intelectual de Adolf von Harnack como também pela sua grandeza moral e por sua estima com a pessoa humana. Barth ouviu de Harnack que o cristianismo é uma criação do apóstolo Paulo e da igreja tardia ${ }^{32}$.

Barth estudou na Universidade de Tubingen entre os anos de 1907 e 1908, por insistência de seu pai que queria que ele conhecesse um pouco da teologia conservadora, mas a experiência não foi muito boa e Barth teve dificuldades de adaptação ao sistema de ensino adotado em Tubingen ${ }^{33}$, e por isso, mudou mais uma vez.

Antes de ter o título de bacharel em teologia, Barth passou pela Universidade de Marburgo, onde foi aluno do professor Wilhelm Hermann (1846 - 1922), de quem aprendeu que a antropologia não pode ser resolvida fora do encontro com o Deus vivente e que a vida religiosa só pode nascer e se desenvolver em contato com a vida de Jesus ${ }^{34}$. Hermann foi o professor por quem Barth teve a maior estima e consideração. Neste período de formação acadêmica, Barth conheceu as obras de Imanuel Kant, de Friedrich Schleiermacher, que muito o influenciou, de Albrecht Ritschl (1822 - 1889) e outros mais.

Durante sua passagem por Marburgo, Karl Barth foi escolhido pelo professor Martin Rade (1857 - 1940) para ser seu secretário de redação da revista Die Christliche Welt ${ }^{35}$. Enquanto trabalhava na revista, Barth alcançou o título de bacharel em teologia no ano de 1909.

A formação acadêmica de Karl Barth foi basicamente feita em ambiente liberal, onde se rejeitava a ideia de que a Bíblia fosse a Palavra de Deus escrita ${ }^{36} \mathrm{e}$ havia um intenso clima de euforia com a crítica histórica, consequência do ideal de progresso característico do século XIX e muito presente na escola liberal.

Nos anos de seus estudos universitários, Barth conheceu o amigo que foi seu companheiro até o fim de sua vida, Eduard Thurneysen $(1888-1977)^{37}$, pastor e

\footnotetext{
${ }^{31}$ Ibid, p. 43.

${ }^{32}$ Ibid, p. 44.

${ }^{33}$ Ibid, p. 45.

${ }^{34}$ MONDIN, Battista. o.c. p. 37.

${ }^{35}$ Die Christliche Welt significa O Mundo Cristão.

${ }^{36}$ FILHO, Manoel Bernardino de Santana. o.c. p. 45.

${ }^{37}$ MONDIN, Battista. o.c. p. 37.
} 
teólogo que trabalhou ao lado de Barth em muitas ocasiões, com quem manteve amizade até sua morte.

\section{2 .2}

\section{Safenwil e início do magistério (1911 - 1933)}

Em 1911 Barth começou o seu pastorado em Safenwil que era uma pequena vila que ficava no cantão suíço de Aargau, depois de ter sido pastor auxiliar durante dois anos em Genebra. Este período foi muito importante não apenas para a vida como para o pensamento de Karl Barth. Lidar pastoralmente com pessoas simples foi uma experiência decisiva em sua vida. O contato pastoral mexeu tanto com Barth que neste período em que cuidou das pessoas da pequena vila de Safenwil, escreveu e publicou o seu comentário da Carta aos Romanos em 1919, esta obra foi um dos principais trabalhos de sua vida e o início histórico do que ficou conhecido como Neo-Ortodoxia. A Carta aos Romanos foi uma reação eficiente contra o Liberalismo Teológico e tornou Barth conhecido em toda a Europa.

Enquanto pastor em Safenwil, Barth começou a desenvolver a obra mais extensa de sua vida, a Dogmática Cristã. Ainda no período de pastoreio, Barth percebeu que tinha de mudar o nome de sua obra para Dogmática Eclesiástica, pois entendeu que a teologia não era um exercício meramente acadêmico feito por especialistas, mas era feita pela própria igreja, por pessoas que viviam uma experiência de fé. Barth definia a dogmática como a ciência pela qual a Igreja, no nível dos conhecimentos que possui, justifica para si mesma o conteúdo de sua pregação $^{38}$.

Depois da experiência como pastor auxiliar em Genebra, Barth obteve sua ordenação como VDM (Verbi Divini Minister), ou seja, como Ministro da Palavra Divina, passando a ser oficialmente pastor da Igreja Reformada Suíça.

Na prática pastoral, Barth teve uma séria crise pessoal quando percebeu que todo o método liberal, que tinha aprendido em sua formação acadêmica, não estava sendo o suficiente para o serviço eclesial e notava que as pessoas continuavam vazias depois dos sermões semanais que pregava. Ao buscar ajuda nos teólogos de seu tempo, Barth percebeu que eles nada tinham para ajudar um

\footnotetext{
${ }^{38}$ BARTH, Karl. Esboço de uma Dogmática. São Paulo: Fonte Editorial, 2006. p. 7.
} 
pastor de comunidade pequena e simples, foi neste momento que Barth mergulhou nas páginas da Bíblia e descobriu um mundo diferente e maravilhoso ${ }^{39}$.

A vida e a teologia de Barth passaram a ser intimamente envolvidas com a Bíblia, o teólogo denunciou a própria igreja quando esta não levava as Escrituras a sério. Barth denunciou os cristãos que apenas folheavam a Bíblia em lugar de lêla, os que citavam a Bíblia em lugar de vivê-la e deixá-la falar, Barth orava para que a Bíblia nunca deixasse de fazer sentido à vida dos cristãos ${ }^{40}$.

A experiência comunitária em Safenwil aliada à omissão dos principais nomes da teologia liberal ante aos fatos que culminaram na Primeira Guerra Mundial, fizeram Barth romper definitivamente com o Liberalismo Teológico, e a Carta aos Romanos evidencia este processo. Ela foi o resultado não apenas desta ruptura, como do encontro de Barth com as Escrituras. Diante disso, Barth se convenceu de duas coisas muito importantes: primeiro que a Teologia é produto da comunidade de fé e, segundo, que a tarefa do pregador é importantíssima para a pastoral, pois sem a pregação cristã, os teólogos se entregariam a murmúrios inaudíveis sobre Deus ${ }^{41}$. Para Karl Barth, a Palavra de Deus era possibilitada por três fatores importantíssimos e inseparáveis: o principal era a Revelação de Deus, esta que foi registrada no que chamamos de Bíblia e, por fim, esta Revelação registrada nas páginas da Bíblia deve ser proclamada, afinal, como ouvirão se não há quem pregue? ${ }^{42}$.

Quando Barth foi convidado para falar de sua teologia para um grupo de pastores em 1922, deixou claro que a pregação deve constituir o centro do ministério pastoral, e que o pastor deve harmonizar a realidade do conteúdo da Bíblia com a problemática da vida das pessoas, pois assim sendo, esta Palavra suscitaria vida no coração do ser humano. Barth diz que pregar é, com seu pensamento ou coração, acrescentar algo aquilo que deverá ser lido da Bíblia ${ }^{43}$.

Safenwil era uma vila dominada por duas famílias que disputavam a economia local. Uma dessas famílias era de paroquianos de Barth. Os trabalhadores da vila tinham péssimas condições de trabalho e salários injustos.

${ }^{39}$ HORDERN, William E. o.c. p. 167.

${ }^{40}$ BARTH, Karl. Pai Nosso - a Oração que Jesus Ensinou aos Discípulos. São Paulo: Editora Novo Século, 2003. p. 42.

${ }^{41}$ HORDERN, William E. o.c. p. 166.

${ }^{42}$ Cf. Rm 10:14.

${ }^{43}$ BARTH, Karl. Dificuldade e Promessa da Proclamação Cristã in: ALTMANN, Walter (Org.). Dádiva e Louvor: Karl Barth Artigos Selecionados. 2ed. São Leopoldo: Editora Sinodal, 1996. p. 51. 
As mulheres e até as crianças eram submetidas a duras jornadas de trabalho ${ }^{44}$. Diante do quadro de tamanha opressão social na vila, Barth usou todos os recursos que dispunha para travar uma árdua batalha em defesa dos trabalhadores locais. As aulas de catecumenato e o púlpito de sua igreja também eram lugares de defesa dos mais pobres. Assim Barth teve sérios problemas, primeiro com as duas famílias que dominavam aquele povo economicamente e depois com a própria Igreja Reformada.

A luta político-social de Barth em Safenwil foi incansável. A igreja, pastoreada por ele, ficou ao lado dos explorados pelo voraz sistema financeiro da localidade. Barth não teve pudor em descer do púlpito e ir para as ruas mostrando sua firme confiança em Deus.

Barth não teve uma postura dualista diante da fé que abraçava, e para ele esta fé consequentemente o impelia em lutar contra a mentira, mesmo que esta fosse ideológica. Crer em Deus e ser santo significava para ele lutar pela justiça. Definia santidade não de modo dualista como a separação do mundo, mas a separação para o mundo para lutar por um mundo mais justo e verdadeiro, algo que não estava acontecendo em Safenwil, pois aquela situação só beneficiava uma minoria poderosa em detrimento de toda a população que era explorada. Para Barth comprometer-se com Deus significava estar comprometido com aqueles a quem Deus amou.

Como citado, uma das famílias mais poderosas de Safenwil fazia parte da igreja onde Barth pastoreava e, nem isso, fez com que ele se calasse. Quase todos os trabalhadores locais eram empregados da indústria. A família Hüssy, da igreja de Barth, era dona de tecelagens onde mulheres eram massacradas com salários indignos e sem o mínimo de direitos trabalhistas ${ }^{45}$, pois nem o direito de participação em sindicatos, estes tinham.

Karl Barth incentivou a formação de grupos que funcionariam como sindicatos de trabalhadores industriais que lutariam por melhores condições socioeconômicas para os mesmos. Barth fez palestras nesses sindicatos. Suas palestras falavam sobre os direitos humanos e as obrigações cívicas, além do slogan lançado por ele em 1912: salário, trabalho, vida ${ }^{46}$. É claro que o industrial

\footnotetext{
${ }^{44}$ SCHULER, Roberto, Prefácio in: BARTH, Karl, o.c. p. 11

${ }^{45}$ FILHO, Manoel Bernardino de Santana. o.c. p. 64.

${ }^{46} \mathrm{Ibid}, \mathrm{p} .65$.
} 
da família Hüssy reagiu contra Barth fazendo-lhe críticas pesadas e um dos membros desta mesma família, que era presidente do conselho da igreja em que Barth pastoreava, pediu demissão do cargo em protesto ao engajamento do pastor.

Ainda em Safenwil, Barth se filiou ao Partido Social Democrático Suíço e estava convencido de que as demandas sociais deveriam ser aplicadas sob o auxílio do Evangelho. Naquela cidade, Karl Barth praticou o Evangelho de Jesus ao compartilhá-lo com os seus paroquianos, com empregados da indústria têxtil, com pessoas que eram marginalizadas e exploradas pelo sistema até então vigente naquele contexto ${ }^{47}$.

Karl Barth fez uma palestra em 1919, com o título: O Cristão na Sociedade, na Conferência social-religiosa em Tambach. Nesta palestra, afirmou que retirarse da vida não é algo possível, e que como cristãos devemos estar envolvidos com a vida humana e as suas mazelas. Barth entendeu que a sociedade não está abandonada ainda que ande em caminhos errantes, pois Cristo está em nós, nos seus discípulos, e que nossa atuação neste mundo revelará os princípios divinos de ética e justiça ${ }^{48}$.

Para Barth o real sentido da religião está em seu relacionamento com a vida real, com a vida da sociedade, e não em seu isolamento. Barth denunciou a inércia da igreja em relação aos que estariam longe da própria igreja, e diz que não se podia falar dos que estão dentro enquanto houver ao menos um que esteja lá fora $^{49}$. Não há outra maneira dos discípulos de Jesus obedecer ao chamado do discipulado que não estando próximo da sociedade.

O teólogo ressaltava a necessidade de abandonarmos o isolamento tendente das instituições religiosas e passar a contar com a força do Deus vivo, pois se assim fizermos, será criado um novo mundo e, caso contrário, qualquer tentativa de mudança social que se pretenda não passará de uma sociedade secular onde se acrescente aspectos eclesiásticos ${ }^{50}$. O fato de nos submetermos a Deus no mundo é o que nos dá coragem para não nos submetermos ao mundo sem Deus ${ }^{51}$.

No entendimento do teólogo da Basileia, toda e qualquer tendência de dualismo entre igreja x sociedade, sagrado x profano deve ser superado, pois se

\footnotetext{
${ }^{47}$ Ibid, p. 17.

${ }^{48}$ BARTH, Karl. O Cristão na Sociedade in: ALTMANN, Walter (Org.). o.c. p. 20.

${ }^{49}$ Ibid, p. 21.

${ }^{50}$ Ibid, p. 23 .

${ }^{51}$ Idem.
} 
Deus ficasse preso a este dualismo, Ele não seria Deus. Deus produz em nós inquietude nos levando a uma posição crítica diante de toda a situação políticosocial, que se oponha a justiça e a ética do Reino de Deus. Essa inquietude é um movimento de vida para a vida, é sofrer junto às queixas de todos os nossos contemporâneos $^{52}$. Para Barth não podemos nos colocar como meros expectadores ao lado das mazelas do mundo, mas como discípulos de Cristo temos que, obrigatoriamente, assumirmos uma postura de solidariedade para com o mundo degenerado.

O engajamento político-social expresso na vida de Barth era consequência da teologia produzida por ele: em 1922 quando ele já lecionava em Gottingen, publicou a segunda edição de seu comentário da Carta aos Romanos, que seria uma reelaboração completa da primeira edição publicada três anos antes. Nesta obra, Barth elabora a tese de que Deus é o Totalmente Outro. Deus é Deus, Ele não se confunde com o mundo como os liberais haviam proposto. Para Barth, Deus e o mundo são dois entes distintos, assim sendo, Deus salvou o mundo se revelando em Jesus Cristo e vindo ao seu encontro, ao encontro da humanidade perdida.

O Deus que para Barth era o Totalmente Outro, só se revela em Jesus, e qualquer tentativa humana de conhecê-lo não passará de becos sem saídas. Nenhum caminho vai do homem a Deus, nem através da experiência religiosa, proposta por Schleiermacher, nem pela via histórica proposta por Ernest Troeltsch (1865 - 1923). O único caminho vai de Deus para o homem e se chama Jesus Cristo $^{53}$.

A única maneira que temos de falar de Deus é através da Revelação, e Jesus Cristo é a perfeita e plena revelação de Deus. Portanto, se quisermos falar de Deus ou conhecermos sua verdadeira imagem devemos olhar para Jesus. Jesus é aquele que nos revela perfeitamente quem é Deus e quem é o ser humano. Assim sendo, falar de Deus é falar do ser humano. Crer em Deus é lutar pelo bem estar de suas criaturas, daqueles por quem Jesus veio a Terra para salvar.

Enquanto trabalhava como professor em Bonn, Barth experimentou uma mudança significativa em seu pensamento, esta mudança aconteceu através de

52 Ibid, p. 27.

${ }^{53}$ GIBELLINI, Rosino. A Teologia do Século XX. 2ed. São Paulo: Editora Loyola, 2002. p. 21 . 
seus estudos de Santo Anselmo da Cantuária. Barth abandonou a dialética para abraçar a analogia. Ele percebeu que apenas através da analogia era possível chegar à compreensão do conteúdo da Revelação. Só que esta analogia não podia ser a analogia do ser, pois esta é uma categoria humana e imprópria para compreender a Revelação. Devemos receber a Revelação de Deus por meio da analogia da fé, não por parte da razão ${ }^{54}$.

Na obra que Barth escreveu sobre Anselmo da Cantuária, deixou claro que a condição da existência da teologia é a fé. Barth rejeitou a ideia liberal de que fosse possível fazer uma teologia meramente científica. Para ele era impossível uma teologia destituída da fé ${ }^{55}$.

Karl Barth desde a sala de aula ensinava aos seus alunos a importância do engajamento político-social, insistindo que seus alunos fossem ávidos leitores e que a sua formação acadêmica não excluísse a realidade da vida. Para Barth todo estudante de teologia deveria ter numa das mãos a Bíblia e na outra mão os jornais, para que pudessem harmonizar o conteúdo da fé com a realidade do ser humano.

Barth nunca fez separação entre o pastor, o teólogo e o político. Para ele uma coisa levava à outra. Era engajado porque cria no Evangelho de Jesus e, como consequência disso lutava em prol dos mais fracos e explorados. Barth entendia que Jesus não nos chamou para fazermos parte de uma nova religião, mas nos chamou para o discipulado e não existe discipulado sem aquele que nos chamou. Para seguirmos o discipulado proposto por Jesus é necessário obediência e fé. Fé não é obediência, mas como obediência não é obediência sem fé, fé não é fé sem obediência ${ }^{56}$.

Embora tenha sido profundo e reconhecidamente brilhante no que escrevia e produzia, Karl Barth não foi um teólogo de escritório, mas um teólogo que buscava produzir algo que fosse encarnado com a vida humana.

\footnotetext{
${ }^{54}$ MONDIN, Battista. o.c. p. 40.

${ }^{55}$ BARTH, Karl. Fé em Busca de Compreensão. 3ed.São Paulo: Fonte Editorial, 2006. p.

${ }^{56}$ BARTH, Karl. Chamado ao Discipulado. São Paulo: Fonte Editorial, 2006. p. 25.
} 34. 


\section{3 \\ Segunda fase: Karl Barth entre 1933 - 1945}

Sem dúvida este período foi um momento de muita tensão não apenas na Alemanha, onde estava vivendo Karl Barth, mas em toda a Europa e posteriormente, um momento trágico para toda a humanidade.

Foi um período em que a economia da Alemanha lutava arduamente para tentar se recuperar. O país ainda estava humilhado pelas decisões do Tratado de Versalhes e a situação política ainda era frágil. Foi neste contexto que o Partido Nacional Socialista chegou ao poder.

Barth foi um dos líderes cristãos que desde o início lutou contra o regime nazista na Alemanha, sua luta foi dura. Barth sofreu sérias consequências como será visto mais detalhadamente no decorrer deste capítulo. No ano de 1939 quando a Segunda Guerra Mundial começou o título de doutor honoris causa da Universidade de Munique, conferido a Barth em 1922, foi cassado.

Em 1935 Barth aceitou o convite para ensinar na Universidade da Basiléia, na Suíça, e deixou a Alemanha depois de quase quinze anos. Neste período, Barth continuou desenvolvendo sua obra e foi premiado com mais três títulos de doutor honoris causa, desta vez pelas Universidades de Utrecht, na Holanda, St. Andrews, na Escócia e, Oxford, na Inglaterra.

Barth foi proibido de publicar as suas obras na Alemanha, e passou a fazê-lo na Suíça. Neste período publicou mais três volumes da sua Dogmática. Sua produção teológica continuou de modo intenso, chegou ao auge de sua maturação intelectual e despontou como uma voz profética numa região dominada pelo totalitarismo e pelo desprezo aos direitos humanos.

Também foi um período de perdas pessoais para Barth. Em 1938 morreu sua mãe, Anna Sartorius Barth, e em junho de 1941 morreu um de seus filhos prematuramente, o jovem de apenas 20 anos de idade, Mathias Barth. Era estudante de teologia e se acidentou em viagem que fizera às montanhas da Suíça.

Entre 1933 e 1945, certamente o fato mais importante na história de Barth foi sua relação com o regime nazista na Alemanha e a Segunda Guerra Mundial. Barth não denunciou o nazismo apenas quando viu os resultados dos campos de concentração ou os efeitos destrutivos da guerra, mas antes mesmo de Hitler revelar sua face mais obscura, Barth já denunciava os abusos cometidos pelo 
regime e via com muita desconfiança toda aquela euforia que circulava no país. Barth lutou na Alemanha enquanto pôde e depois, mesmo fora do país, continuou fazendo a sua parte incansavelmente testemunhando seu compromisso com Deus e com o Evangelho. Para Barth toda invocação a um Füher era tão vã quanto o grito dos sacerdotes de Baal: Baal! Escuta-nos! ${ }^{57}$

\section{1 O contexto histórico da Alemanha entre 1933-1945}

Este foi o período que marcou profundamente não apenas a história alemã ou européia, mas a história da humanidade. Durante pouco mais de uma década, a Europa viveu o surgimento do nazi-fascismo, um movimento basicamente militar e ultranacionalista que tinha grande aversão pelo liberalismo, que caracterizou o pensamento europeu até a Primeira Guerra Mundial. O liberalismo gerou reações radicais na Europa no período posterior à Primeira Guerra Mundial. A Alemanha e a Itália abraçaram o nazi-fascismo, já a Rússia (até 1917, czarista) promoveu uma revolução socialista e, ambos os modelos (nazi-fascismo e socialismo) além de contrários ao liberalismo eram antagônicos entre si.

Neste movimento que começou na Itália na década de 20 sob a liderança de Benito Mussolini (1883 - 1945) e encontrou na Alemanha sua maior expressão sob o austríaco Adolf Hitler, caracterizava-se por ser um regime totalitário em que o Estado tinha poder e domínio sobre a sociedade. Havia o culto à personalidade (Duce na Itália, Fuher na Alemanha), além do sistema político monopartidário e a eugenia, ou seja, a busca pela purificação racial, no caso alemão apenas os arianos eram considerados a raça pura e todas as outras raças eram consideradas inferiores e, portanto, tinham de ser subjugadas.

Os historiadores concordam que o ultranacionalismo das décadas de 20 e 30 teve tudo a ver com o pensamento liberal do século anterior, sendo, portanto uma reação, e foi consequência da desilusão humana com o que aconteceu com o antigo sentimento de otimismo. Duas consequências daquele modelo, que se mostrou fracassado, foram a Primeira Guerra Mundial e a Quebra da Bolsa de Nova Iorque.

\footnotetext{
${ }^{57}$ MONDIN, Battista. o.c. p. 41 .
} 
Outro ponto de concordância entre os historiadores é que o sentimento nacional alemão não conseguia se recuperar da profunda humilhação que sofreu com o Tratado de Versalhes e o desfecho da Primeira Guerra. O Nazismo cresceu por causa do orgulho alemão que estava ferido, foi uma espécie de revanchismo. Na prática, a Segunda Guerra Mundial foi uma continuação da Primeira Guerra, a guerra inacabada.

\subsection{1}

\section{A ascensão do Nazismo (1933 - 1939)}

Como já fora dito, a Alemanha do início da década de 30 estava mergulhada num verdadeiro colapso econômico. O historiador Eric Hobsbawm fala em sua obra que o efeito traumático que este colapso gerou nas classes média e média baixa, deixou a Europa Central pronta para o fascismo ${ }^{58}$. A taxa de desemprego era extremamente elevada, a moeda alemã (o marco) era constantemente desvalorizada.

O medo de uma Revolução Bolchevista fez nascer o ultranacionalismo, que em princípio, fora apoiado até mesmo pela igreja, que também compartilhava do mesmo medo em relação ao comunismo, até porque durante a República de Weimar havia grupos comunistas fortes no país que eram incentivados pela União Soviética e que planejavam um golpe. Este medo estimulou os capitalistas a subsidiarem os movimentos fascistas, especialmente os setores ligados à grande indústria e aos bancos.

Durante a República de Weimar (1919 - 1933) a Alemanha ganhou uma constituição inspirada nos moldes liberais, era uma tentativa republicana depois da queda do II Reich, porém, como vimos, a Republica de Weimar se tornou politicamente frágil.

Em 1923, Hitler participou de um movimento golpista que tentou derrubar o governo da Baviera ao lado do marechal Ludendorff (1883 - 1919), a tentativa de golpe foi frustrada e Hitler ficou preso por cinco anos, neste período escreveu a obra Minha Luta, que se tornou uma grande referência para o nazismo alemão. É curioso citarmos que neste processo que condenou Hitler acusado de traição, ele acabou ganhando fama no país, já que seu processo durou mais de 20 dias e ele

\footnotetext{
${ }^{58}$ HOBSBAWM, Eric. Era dos Extremos 1914 - 1989. p. 95.
} 
teve a oportunidade de discursar livremente usando todo o seu potencial de oratória, espalhando assim sua mensagem ${ }^{59}$.

Em 1933, mesmo contra vontade, o presidente Hindenburg teve de nomear Hitler como chanceler para um governo de coalizão, como consequência das eleições anteriores que davam relativa maioria ao Partido Nacional-Socialista. Só que os nazistas ainda não detinham o poder político naquele momento, ainda havia uma oposição bastante combativa na Alemanha, mas Hitler para obter a maioria decidiu dissolver a Assembléia e convocar novas eleições para março.

As novas eleições não foram livres, o partido de Hitler usou todas as manobras possíveis para ter vantagem no período de campanha eleitoral. Hitler proibiu os comícios e a imprensa comunistas e pessoas ligadas ao partido nazista se infiltraram para perturbarem a ordem das reuniões do Partido SocialDemocrático e do Partido Centrista Católico ${ }^{60}$.

A maior de todas as artimanhas de Hitler foi o incêndio ao prédio do Reichstag (o parlamento alemão) no dia 27 de fevereiro de 1933, o intento foi de colocar a culpa nos comunistas e acusá-los de tramarem um golpe de Estado na Alemanha, algo parecido com o chamado Plano Cohen que Getúlio Vargas (1882 - 1954) fez no Brasil para dar o golpe do Estado Novo em 1937. Nunca houve provas concretas de que o incêndio foi mesmo provocado pelos comunistas, o curioso é que logo no dia seguinte ao incidente, Hitler conseguiu junto ao presidente Hindenburg um decreto que suspendia algumas seções da Constituição de Weimar, como a liberdade de imprensa, de opinião e de reunião, ou seja, a liberdade foi seriamente restringida no país. A inviolabilidade de correspondências, telegramas e telefonemas também foi quebrada. Em seguida, jornais ligados aos sociais-democratas e aos liberais também foram cerceados.

Neste processo eleitoral, muitos líderes comunistas, sociais-democratas, liberais foram presos, o resultado das eleições deu uma considerável vantagem a Hitler embora sem a maioria pretendida no Reichstag: seu partido alcançou $44 \%$ dos votos. Para controlar o parlamento, Hitler proibiu a entrada de 81 deputados comunistas e vários sociais-democratas ${ }^{61}$.

${ }^{59}$ LUTZER, Erwin. A Cruz de Hitler. São Paulo: Editora Vida, 2003. p. 55.

${ }^{60}$ CORNU, Daniel. Karl Barth Teólogo da Liberdade. Rio de Janeiro: Editora Paz e Terra, 1971.p. 12.

${ }^{61}$ Ibid, pg. 13. 
O chanceler alemão passou a ter direitos de aprovação de tratados internacionais, e de emendas constitucionais, além de não ser mais fiscalizado pelo Reichstag. No meio de tantas transformações políticas, o Partido NacionalSocialista (Nazista) foi o único autorizado a funcionar, um duro golpe à democracia alemã e o estabelecimento do monopartidarismo e do totalitarismo nazista. Neste mesmo ano de 1933 é fundada a Gestapo, a polícia nazista, uma das principais ferramentas ditatoriais de Adolf Hitler.

$\mathrm{O}$ poder de Hitler ficou ainda maior quando o presidente Hindenburg morreu em 1934, e o chanceler passou a acumular a função de presidente, fundindo as funções na posição de Füher do Reich alemão.

Logo neste primeiro momento, Hitler convocou um boicote contra os comércios de judeus em todo o país. Hitler argumentava que a falta de emprego e de dinheiro para o povo alemão era culpa dos judeus que detinham os melhores empregos e acumulavam riquezas. Os judeus representavam uma importante força política na Alemanha daquela época. O povo judeu foi escolhido como o inimigo da nação alemã e Hitler intensificava assim a eugenia.

Em 1934 houve a chamada noite dos longos punhais, quando dissidentes do Partido Nazista foram eliminados por se oporem a atuação política de Hitler e de sua aproximação com setores da grande indústria ${ }^{62}$. Em 1935, os judeus foram excluídos do direito de voto, expulsos dos empregos públicos e perseguidos, o que gerou uma grande emigração.

O período dos seis primeiros anos do nazismo no poder representou uma quase milagrosa recuperação da economia alemã: o PIB cresceu próximo aos $10 \%$ por ano, o crescimento da indústria foi superior a $17 \%$ e a taxa de desemprego teve quedas consideráveis, o que fazia a popularidade do Füher crescer ainda mais.

Foi também neste período que aconteceu a política de dominação e expansão do nazismo, com o pretexto de integrar as comunidades alemãs que viviam fora da Alemanha. Em 1938 Hitler, que era austríaco, anexou a Áustria, num episódio que ficou conhecido como Anschluss. Depois da Áustria, Hitler anexou a região do Sudetos que ficava entre a Alemanha, a Tchecoslováquia e a Polônia, pertencendo anteriormente aos tchecos. Esta era uma região de população 287.

${ }^{62}$ AQUINO, Rubim de; RESENDE, Clymene; FRANCO, Denise e LOPES, Oscar. o.c. p. 
alemã. A região de Dantzig no norte da Polônia também foi anexada, esta região depois do Tratado de Versalhes foi considerada uma cidade livre ${ }^{63}$. Na prática, Hitler estava reconquistando todas as regiões que foram colônias da Alemanha e que foram retiradas de seu domínio por causa do famigerado Tratado de Versalhes, o sentimento revanchista era muito forte nos alemães.

Fora as anexações, Hitler invadiu a Polônia e a Ucrânia, pois considerava as duas nações uma região importante para o povo alemão. Com isso, o regime nazista voltava a dominar o chamado corredor polonês, que pertenceu anteriormente aos alemães e foi devolvida à Polônia através do Tratado de Versalhes.

Enquanto Hitler seguia sua política de dominação e expansão, as potências europeias, Inglaterra e França, usavam suas estratégias de apaziguamento, o que mais tarde vai lhes custar muito caro, sobretudo para a França. A estratégia de ingleses e franceses era criar um choque futuro entre a Alemanha de Hitler e a União Soviética de Stálin. Em 1939, alemães e soviéticos assinaram um acordo de não-agressão mútua e com a invasão da Polônia em setembro de 1939 começou formalmente a Segunda Guerra Mundial ${ }^{64}$.

\subsection{2}

\section{A Segunda Guerra Mundial (1939 - 1945)}

A Segunda Guerra Mundial foi uma continuação da Primeira Grande Guerra, ainda mais porque entre 1918 e 1939 aconteceu a Quebra da Bolsa de Nova Iorque gerando a Grande Crise e a Grande Depressão.

Não há dúvidas de que a Grande Depressão foi um incentivo à Segunda Guerra, uma vez que a exacerbação das medidas contra a crise acabou por gerar movimentos e sentimentos ultranacionalistas em diversos países, especialmente na Alemanha e na Itália. No Japão a grande indústria também foi afetada e o país sofreu com o clima de disputas internacionais resultantes da crise.

Nesses países, as consequências da crise econômica e o medo da revolução socialista deram fôlego aos movimentos nacionalistas, que surgiram como uma alternativa ao comunismo. Assim aconteceu na Alemanha, com o nazismo, na

\footnotetext{
${ }^{63}$ BLAINEY, Geoffrey. Uma Breve História do Século XX. São Paulo: Editora Fundamento Educacional, 2009. p. 126.

${ }^{64} \mathrm{Ibid}, \mathrm{pg} .288$.
} 
Itália, com o fascismo, no Japão e até em países como a Espanha e o próprio Brasil.

Além de toda a política expansionista da Alemanha, que anexou e reocupou várias regiões da Europa Central na década de 30, seus aliados também apostaram na mesma política: a Itália conquistou a Etiópia em 1936 e a Albânia em 1939, já o Japão dominou a região da Manchúria pertencente a China entre 1931-1932, e também usou a força contra a Mongólia afim de ampliar seus limites. Os japoneses desejavam ser o grande líder do Pacífico. Entre 1937 e 1945 o Japão tentou suplantar a China.

A Alemanha, além das invasões, remilitarizou a região da Renânia. Em 1936 dois acordos de grande importância foram assinados, o primeiro entre Hitler e Mussolini formando o Eixo ítalo-germânico e posteriormente, Alemanha, Itália e Japão assinaram um acordo anti-comunismo, ampliando assim a aliança no Eixo Roma-Berlim - Tóquio ${ }^{65}$.

Esse contexto aproximava Alemanha, Itália e Japão, de um lado e de outro lado os aliados Inglaterra, França e Estados Unidos se alinhavam. Numa terceira coluna aparecia a União Soviética, temida e odiada por ambos os grupos.

A Segunda Guerra Mundial começou no dia $1^{\circ}$ de setembro de 1939 quando a Polônia foi invadida pela Alemanha ${ }^{66}$. Podemos dizer que nos três primeiros anos da guerra (1939 - 1942) as forças do Eixo, lideradas pelos alemães obtiveram uma expressiva vantagem sobre os países aliados. O Eixo tinha construído uma poderosa máquina de guerra e fazia expansões avassaladoras pela Europa.

Em apenas três anos, os alemães conquistaram a Dinamarca, a Noruega, os Países Baixos (Holanda, Bélgica e Luxemburgo) e boa parte da poderosa França. O impacto das invasões na França foi enorme, o território foi dividido em zonas de ocupações alemães e italianas, um Estado de colaboração foi criado: a chamada França de Vichy e a França Livre precisou se reorganizar sob a liderança do general Charles de Gaulle (1890 - 1970). A Inglaterra foi a única potência europeia que resistia na luta contra os nazistas sem sofrer perdas territoriais, embora tenha sofrido com a marinha alemã e bombardeios. 295.

${ }^{65}$ AQUINO, Rubim de; RESENDE, Clymene; FRANCO, Denise e LOPES, Oscar. o.c. p.

${ }^{66}$ A Polônia também fora invadida pela União Soviética. 
Além dessas frentes, os alemães ajudaram os italianos a conquistarem a Grécia e a Iugoslávia, o Egito no norte da África também foi conquistado e no Extremo Oriente, o Japão dominou o norte da China e se expandiu pelo Sudeste Asiático e pelo Pacífico Sul ${ }^{67}$. Até 1942, o Japão havia conquistado também Indonésia, Birmânia, Malásia e Filipinas e já se preparava para dominar a Índia e a Austrália.

O poderio de alemães na Europa e de japoneses no Oriente e Pacífico deixaram as forças aliadas um tanto quanto atônitas. O desejo de expansão das forças do Eixo pareciam não ter fim, e a hostilidade bélica dessas nações também não. Em três anos as conquistas foram enormes e poucos foram os países das regiões afetadas que não sofreram invasões das tropas do Eixo: Austrália e Nova Zelândia no Pacífico, Suécia, Portugal, Espanha e Suíça (de Karl Barth) na Europa.

Alguns historiadores chegam a afirmar que por pouco as forças do Eixo não tiveram a vitória nessa Guerra Mundial e dois episódios foram os responsáveis por evitar um possível triunfo nazista na ocasião: os ataques japoneses às bases americanas em Pearl Harbor no Havaí e a precipitada invasão alemã na União Soviética, violando assim o tratado de não-agressão assinado anos antes. Os dois episódios aconteceram em 1941 e forçou um grande engajamento de Estados Unidos e União Soviética, que até então se mantinham mais afastados dos conflitos contra os nazistas.

Se os três primeiros anos da guerra representaram um enorme avanço das forças do Eixo, o ano de 1942 foi importante no desenrolar do conflito, pois neste período as forças aliadas conseguiram conter o avanço nazista e se preparar para o contra-ataque. Esta virada se deu devido ao poderio bélico de Estados Unidos e União Soviética que a esta altura já estavam plenamente engajados na guerra.

O período entre 1942-43 foi um momento em que os países do Eixo experimentaram suas primeiras derrotas significativas: o Japão foi derrotado pelos norte-americanos nas batalhas de Midway e de Guadalcanal, na primeira freou a investida japonesa contra o Havaí e a segunda foi uma batalha nas Ilhas Salomão que frustrou os planos do Japão em conquistar a Austrália. 297.

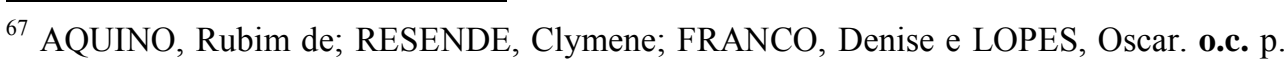


No Norte da África, os ingleses venceram as tropas do Afrika Korps, no Egito e em companhia dos americanos, estabeleceram bases na Argélia e no Marrocos, mas a derrota mais expressiva foi a dos alemães em Stalingrado, na União Soviética. Foi uma derrota muito expressiva que pôs fim ao mito de invencibilidade das tropas de Hitler $^{68}$.

Por fim vieram os últimos anos da guerra. Entre 1943-45 foi o período da vitória final dos aliados e a queda dos nazi-fascistas. A Itália foi o primeiro país a cair, as tropas aliadas invadiram o país pela Sicília. Depois que a conquistaram via Norte da África, em 1943, o ditador Benito Mussolini foi deposto e a Itália se rendeu incondicionalmente em 8 de setembro daquele mesmo ano, os alemães ainda tentaram defender a Itália e libertar Mussolini, que foi fuzilado em 1945.

A batalha contra a Alemanha começou a partir da libertação da França com o desembarque pela Normandia e pelos ataques realizados pelos soviéticos contra o Leste europeu que obrigou a rendição de Finlândia, Bulgária e Hungria, e a ocupação da Polônia, Romênia, Tchecoslováquia e Iugoslávia.

Adolf Hitler já estava com a saúde debilitada tendo problemas cardíacos e mal de Parkinson, parece que semanas antes da morte teve um colapso nervoso ao perceber que a derrota já se aproximava. Ao prever o inevitável fim, Hitler pediu orientação a um médico a respeito de suicídio, que o fez sem arrependimento depois de se casar com a noiva Eva Braun (1912 - 1945), no dia 30 de abril de 1945.

As investidas soviéticas resultaram na dominação de Berlim em 2 de maio de 1945 dois dias após o suicídio de Adolf Hitler. No dia 8 de maio, após ter sido invadida por todos os lados, a Alemanha se rendeu incondicionalmente.

O último país do Eixo a se render foi o Japão, naquele momento o mundo já dava seus primeiros passos rumo à transição: seria o início da chamada Guerra Fria, um conflito indireto entre Estados Unidos e União Soviética que duraria até o início da década de 90. Como uma vingança dos ataques sofridos em Pearl Harbor e, sobretudo, como uma manifestação de poder bélico, os Estados Unidos lançaram duas bombas nucleares contra as cidades japonesas de Hiroshima e Nagazaki, causando grande catástrofe.

${ }^{68}$ Idem. 
A Segunda Guerra Mundial terminou oficialmente em 2 de setembro de 1945, com mais de 50 milhões de mortos, dentre os quais mais de 6 milhões de judeus. 11 milhões do total morreram nos campos de concentração nazistas.

Assim que a guerra acabou houve reuniões entre Estados Unidos, União Soviética e Inglaterra (que já vinham acontecendo antes mesmo do término da guerra). O intuito era discutir o futuro da Europa e da Alemanha em específico. As principais resoluções foram o desmembramento da Alemanha e da capital Berlim em quatro zonas de influência cada uma sob o comando de França, Inglaterra, Estados Unidos e União Soviética. Outras decisões importantes desse processo foram: a criação da Organização das Nações Unidas (ONU) que substituiu a ultrapassada Liga das Nações, a divisão da Coréia em Norte sob a influência da União Soviética e Sul sob a influência dos Estados Unidos.

Foi criado um tribunal em Nuremberg para julgar os crimes de guerra, a Alemanha passou por um processo de desnazistificação e pela dissolução da indústria bélica.

É difícil de entendermos como tudo isso aconteceu a partir de um país cuja população era $95 \%$ de cristãos (entre católicos e protestantes). Sem dúvida, a relação entre o Nazismo e o Cristianismo alemão foi assombrosa, a grande maioria dos cristãos alemães não se opôs ao nazismo, pelo contrario, viu com grande entusiasmo a ascensão de Hitler ao poder. Será analisado em seguida esta relação. Karl Barth viveu todo esse período entre a ascensão de Hitler e a Segunda Guerra Mundial e nunca se calou! E mesmo depois do término da Guerra, Barth lutou pela reconstrução alemã e para que os erros do Tratado de Versalhes em 1919 fossem evitados.

\subsection{3}

\section{A relação do cristianismo com o Terceiro Reich}

Analisar a relação entre o cristianismo (tanto católico quanto protestante) com o Terceiro Reich é uma tarefa atordoante, embora necessária. Por volta da década de 30, quando o nazismo ascendeu ao poder na Alemanha, a população cristã era a grande maioria, isso mostra que para assumir o governo, Hitler teria de ter um maciço apoio por parte da enorme quantidade de cristãos do país.

Não podemos esquecer que embora fossem cristãos, esses $95 \%$ dos quais nos referimos, eram alemães e, como tais estavam vivendo num país arrasado 
economicamente e com um sentimento de profunda humilhação diante das consequências da Primeira Guerra Mundial e, sobretudo, do Tratado de Versalhes. Naquele contexto, todo alemão desejava recuperar os tempos de prosperidade e de autoestima nacional, sendo assim esperavam pela chegada de um líder que conduziria a Alemanha a um novo período de sua história, um líder que fosse do povo e que compartilhava o mesmo sentimento que a nação.

Também não podemos esquecer que o movimento que levou Hitler ao poder foi sim, de cunho democrático. Foi eleito pelo povo, ainda que esse processo tenha sido recheado de pequenos golpes por parte dos nazistas, que usaram todos os meios disponíveis (legítimos e ilegítimos) para eliminar a oposição no cenário político alemão até que Hitler pudesse governar praticamente sozinho, sem precisar dar contas a ninguém.

Além do mais, Hitler fez muito em pouco tempo: a economia falida do país se recuperou em menos de cinco anos, a criminalidade foi controlada, um programa de qualificação da mão de obra levando os índices de desemprego quase a zero foi desenvolvido, houve investimentos em infraestrutura, ignorou pontos do Tratado de Versalhes e promoveu a remilitarização do país e a reivindicação de regiões tiradas dos alemães em 1919, como a Renânia, por exemplo ${ }^{69}$. Em síntese, podemos afirmar que Hitler soube tratar o sentimento do povo alemão e devolver ao mesmo a confiança e a autoestima.

Além de todo o talento apresentado por Hitler como líder político, houve certa aura mística acerca de sua pessoa. Hitler foi o alvo de vários atentados e golpes de Estado, mas ele escapou praticamente ileso a todas as tentativas de assassinato e, diante de todas as tentativas frustradas atribuía ao cuidado divino sua integridade. Hitler estava convicto de que a Providência Divina o guardara, pois Deus tinha algum propósito a ser cumprido através dele ${ }^{70}$. Muitos acreditaram que o fuher era de fato protegido por Deus e que por meio dele os ideais divinos para a Alemanha se cumpririam.

A relação entre o cristianismo e a política alemã não começou com o nazismo, ou o Terceiro Reich. O chamado Sacro Império Romano, que começou com a coroação de Carlos Magno (742 - 814) no ano 800 e se estendeu até Napoleão Bonaparte (1769 - 1821) em 1806, teve início com as bênçãos papais de

${ }^{69}$ LUTZER, Erwin. o.c. p. 20.

${ }^{70} \mathrm{Ibid}, \mathrm{p} .44$. 
Leão III (795 - 816) que consagrou Carlos Magno como rei no natal do ano 800. Nesta época houve um aprofundamento na ideia das duas esferas ou a ideia dos dois braços de Deus, que criou um dualismo entre o poder espiritual exercido pelo papa e o poder temporal exercido pelo imperador, que só governava graças às bênçãos papais, cada um desses poderes representava um dos braços de Deus, e desta forma, o papa era o responsável por cuidar das almas dos seres humanos e os imperadores dos seus corpos.

A relação entre o Sacro Império e o cristianismo foi de cumplicidade, o papa avalizou a liderança temporal dos governantes a partir de Carlos Magno e, o Império, em troca, defendia o papa e a igreja. Em 962, com a consagração de Oto I (912 - 973) pelo Papa João XII (955 - 964), deu-se início ao Santo Império Romano Germânico, também conhecido como o Primeiro Reich. Neste primeiro momento há a união entre a Igreja e o Estado ${ }^{71}$.

Já no Segundo Reich (1871 - 1918), no processo que levou à Reunificação Alemã sob a liderança do chanceler Otto Von Bismarck, houve um discurso que o cidadão deveria separar a moralidade exercida em particular e a exercida publicamente, desta forma esvaziou o discurso de ética cristã que deveria ser aplicada em todos os aspectos da vida. Este discurso teve grande impacto na Alemanha e mais uma vez um perigoso dualismo foi criado onde se separava o cristão que cantava e orava nas igrejas, do cidadão que apoiava a liderança de Hitler não se importando com o massacre de judeus e das minorias, com o desprezo do fuher pela democracia, pela paz e pelos direitos humanos. Pessoas como Karl Barth nunca aceitaram este dualismo. Barth fazia questão de não separar o político do teólogo ${ }^{72}$. Certamente este dualismo que começou com Bismarck e foi amplamente explorado por Hitler, foi o responsável, em parte, pela alienação de inúmeros cristãos frente às atrocidades cometidas pelo nazismo.

$\mathrm{Na}$ República de Weimar houve uma constituição liberal no país que pregava a separação entre Igreja e Estado. Até o período do Segundo Reich em 1918, as igrejas protestantes alemães seguiam o regime de soberania, onde os monarcas hereditários e pequenos senhores eram ao mesmo tempo bispos de seus respectivos territórios ${ }^{73}$.

\footnotetext{
${ }^{71} \mathrm{Ibid}$, p. 27.

${ }^{72}$ CORNU, Daniel. o.c. p. 7

${ }^{73} \mathrm{Ibid}, \mathrm{p} .14$.
} 
Com o fim do regime ao término da Primeira Guerra, as igrejas são liberadas de suas obrigações com o Estado. A situação da igreja no país foi totalmente alterada na República de Weimar, ela agora tinha autonomia, porém sentia o clima de insegurança que o novo regime lhe passara e com isso, as massas foram deixando as igrejas pouco a pouco.

Daniel Cornu nos fala em sua obra que o luteranismo alemão não preparou a igreja para a democracia, os protestantes perderam os privilégios com a nova conjuntura política e que a República de Weimar tinha como base os católicos do centro e os socialistas de esquerda ${ }^{74}$. Neste contexto podemos compreender melhor o porquê dos protestantes conservadores apoiarem o nacional-socialismo, pois acreditavam que nele voltariam a ter os privilégios de outros tempos numa nova união entre a Igreja e o Estado.

Os teólogos liberais alemães também viam com entusiasmo essa futura relação que fundiria Igreja e Estado numa única entidade. Barth e outros teólogos ficaram muito decepcionados com a total omissão dos liberais diante da situação política alemã, sobretudo em meados da Primeira Guerra Mundial.

Nessa relação com o cristianismo, o nazismo procurou se respaldar de modo teológico, filosófico e artístico, por exemplo, usou ensinamentos de Martinho Lutero que apontavam para uma espécie de antissemitismo. Fizeram uso da filosofia de Nietzsche $(1844$ - 1900) e Hegel $(1770$ - 1831) para criar a ideia de uma raça pura, de um Super Homem, no qual não havia lugar para a fraqueza, e de um Estado totalitário que faria da Alemanha novamente uma potência mundial recuperando a glória de outros tempos. Ainda que inicialmente estes pensadores não tivessem a intenção de gerar as bases nacionais-socialistas, eles foram deturpados em favor do nazismo. A obra do artista Richard Wagner (1813 - 1883) também foi explorada em seu teor antissemita.

Logo no início da chegada de Hitler ao poder, o jovem pastor e teólogo Dietrich Bonhoeffer (1906 - 1945) fez um discurso em rádio dizendo que a medida que um líder é reverenciado ele se torna um ídolo e um enganador e, ao mesmo tempo, o povo que o idolatrava estava zombando de Deus. Bonhoeffer insistia em dizer que apenas Cristo poderia salvar a igreja naquele momento nevrálgico, o Cristo dos Evangelhos e não um Cristo idolátrico criado pelos

${ }^{74}$ Idem. 
nazistas de teor nacionalista e germanizado. No momento em que falava na rádio, Bonhoeffer teve seu microfone cortado ${ }^{75}$.

Ainda em 1933 foi criado um Sínodo para a criação da Igreja Evangélica Alemã, que era uma tentativa de união de todas as igrejas evangélicas do país debaixo do mesmo espírito do partido nazista, seria a igreja dos cristãos alemães, ou seja, cristãos de raça ariana ${ }^{76}$. O Sínodo era composto por Herman Kapler, (presidente do Conselho Superior da Igreja Evangélica), August Marahrens (bispo luterano) e Albert Hesse (reformado). Nesse sínodo, a intenção era criar o cargo de bispo do Reich. Na ocasião, o eleito pela maioria foi o pastor Friedrich Von Bodelschwingh (1877 - 1946), que no discurso de posse prometeu manter a igreja acima das disputas internas. Era um homem muito respeitado nos círculos eclesiásticos, mas depois de muita pressão teve de renunciar para que Ludwig Muller (1883 - 1945), o preferido de Hitler, assumisse o posto ${ }^{77}$.

Em tudo isso houve uma curiosidade nefasta, o Sínodo que elegeu o bispo do Reich foi realizado na cidade de Wittemberg, onde em 1517, Martinho Lutero deu início à Reforma Protestante.

Nas eleições eclesiásticas os líderes ligados a Igreja Evangélica Alemã obtiveram $75 \%$ dos votos válidos o que lhes renderam uma posição muito confortável. Obviamente os ligados à Igreja Evangélica Alemã receberam maciço apoio de Hitler, mas esses resultados não ficaram sem reação, Karl Barth escreveu na revista Theologische Existenz Heute! (Existência Teológica Hoje!) artigos que condenavam tudo o que estava acontecendo, para ele a igreja desunia o povo e trabalhava contra a nação quando praticava o nacionalismo ${ }^{78}$. As eleições eclesiásticas de 1933 abriram caminho para a Igreja Confessante e a Declaração de Barmen no ano seguinte.

Ludwig Müller, que antes de ser bispo do Reich foi nomeado por Hitler como um ministro para assuntos eclesiásticos, fez a fusão da Juventude Evangélica Alemã com a Juventude Hitlerista dirigida por Baldur Von Schirach (1907 - 1974) ainda no ano de 1933, esta fusão simboliza bem o relacionamento próximo dos chamados Cristãos Alemães com o nazismo. Da Juventude Hitlerista participaram pessoas como o teólogo Joseph Ratzinger (1927 - ), o Papa Emérito

\footnotetext{
${ }^{75}$ LUTZER, Erwin. o.c. p. 154.

${ }^{76}$ FILHO, Manoel Bernardino de Santana. o.c. p. 89.

${ }^{77}$ LUTZER, Erwin. o.c. p. 155.

${ }^{78}$ CORNU, Daniel. o.c. p. 41.
} 
Bento XVI e o teólogo alemão Jürgen Moltmann (1926 - ) num período em que a participação era compulsória, revelando o espírito totalitário do regime nazista.

A Igreja Evangélica Alemã apresentou ao parlamento (Reichstag) uma constituição para a igreja que tinha como lema: um Estado, um povo, uma igreja $^{79}$. Essa constituição tornava a religião num cristianismo hitlerista e afirmava a luta pela independência das igrejas, mas apenas por aquelas que estivessem alinhadas com o Estado. Hitler era visto como o caminho que Deus havia estabelecido para que o povo alemão tivesse comunhão com a igreja de Cristo. Bonhoeffer demonstrou preocupação com os rumos que a igreja do país estava tomando e disse que o verdadeiro cristianismo tinha de enfrentar uma luta contra o germanismo ${ }^{80}$.

Em 1935 o jurista nazista e ex-presidente do parlamento regional da Prússia, Hans Kerrl (1887 - 1941), foi escolhido para o posto de ministro do Reich para assuntos eclesiásticos, sua missão era promover a uniformidade da Igreja Evangélica Alemã. Kerrl estabeleceu leis que iriam controlar muito de perto a igreja da Alemanha, como por exemplo: a igreja perderia sua liberdade para nomear pastores, ou titulares de funções eclesiásticas, de inspecionar paróquias, publicar mandamentos a serem lidos em público, receber ou administrar as contribuições eclesiásticas e ficaria proibida de convocar sínodos por conta própria $^{81}$. Tais atitudes serviram para que o Reich pudesse dominar diretamente a igreja, tirando-lhe sua liberdade e criando barreiras para a própria pregação cristã, o que Barth reagiu imediatamente.

Em 1937, Hitler prometeu novas eleições eclesiásticas com total liberdade de articulação política e de expressão e voto. Com a já criada Igreja Confessante, o pastor Martin Niemoller (1892 - 1984) conseguiu discursar durante algumas noites para milhares de pessoas, porém a promessa de eleições livres nunca se cumpriu e Hitler atacou mais uma vez: estatizou por completo as finanças das igrejas e os exames de ordenações de futuros pastores, proibiu qualquer ajuntamento de pessoas fora dos templos e, além disso, Martin Niemoller foi preso e condenado por abuso da palavra, recebeu uma pesada multa e sete meses de detenção, quando foi liberado por ter passado o tempo de sua prisão

\footnotetext{
${ }^{79}$ LUTZER, Erwin. o.c. p. 155.

${ }^{80} \mathrm{Ibid}$, p. 156.

${ }^{81}$ CORNU, Daniel. o.c. p. 56.
} 
preventiva, Niemoller foi arbitrariamente preso pela Gestapo e enviado para um campo de concentração onde permaneceu por sete anos até a vitória das tropas aliadas ao fim da guerra ${ }^{82}$.

Somente no ano de 1937 mais de 800 pessoas ligadas à igreja foram presas na Alemanha, quase 20 foram mortas até o fim da guerra.

É pertinente citar que houve um trabalho dogmático para enquadrar a mensagem cristã dentro dos moldes nazistas. Além do que já foi dito de sentimento do povo alemão, das articulações de Hitler para dominar as igrejas, da aura mística que se formou ao seu redor, dos fundamentos filosóficos e políticos do movimento, também houve uma arianização do cristianismo.

Jesus não era visto mais como um judeu, mas como um ariano, o Antigo Testamento por se tratar de Escrituras Judaicas, foi praticamente abolido e no Novo Testamento tudo o que apontava nesta direção foi reinterpretado sob o argumento que os judeus haviam corrompido a verdadeira mensagem do cristianismo, uma nova versão do marcionismo.

Vale citar que o texto de Romanos $13 ; 1-2^{83}$ era frequentemente citado para embasar a ideia de que os cristãos não deveriam de maneira alguma se rebelarem contra o fuher porque ao fazer isso, estariam fazendo contra o próprio Deus e trariam condenação sobre si. O Estado era confundido com o próprio Deus, o que Barth comparou com os gritos dos profetas a Baal no episódio bíblico do profeta Elias $^{84}$.

Uma das características da igreja alemã era o nacionalismo, o que contribuiu para a aceitação por parte dos protestantes do discurso nazista. Desde a Reforma Protestante de Martinho Lutero no século XVI, o intuito da fé reformada era de igrejas nacionais, o que seria uma maneira de fortalecer a nação (sua cultura, seu idioma, suas características) até porque este era o momento do apogeu das Nações-Estados. Ter uma igreja nacional e não uma igreja universal como era a igreja católica medieval, era uma forma de romper com o domínio políticoeconômico de um papa que vivia na Itália e concentrava o poder e o dinheiro.

${ }^{82}$ Ibid, p. 59.

${ }^{83} \mathrm{Rm}$ 13;1-2: “Todos devem estar sujeitos às autoridades governamentais, pois não há autoridade que não venha de Deus; as autoridades que existem foram por Ele estabelecidas. Portanto, aquele que se rebela contra a autoridade está se colocando contra o que Deus instituiu, e aqueles que assim procedem trazem condenação sobre si mesmos".

${ }^{84}$ Cf. 1 Rs $18 ; 26$. 
O relacionamento entre cristãos e o poder civil foi sempre comum na cultura protestante alemã, não apenas nas eras dos reichs, como vimos, mas, na época da Reforma várias localidades se convertiam à fé que era abraçada pelo príncipe local. Também devemos citar que o próprio Lutero em sua obra Autoridade Secular, corroborou com o dualismo entre as esferas sagradas e profanas, entre o religioso e o civil. João Calvino (1509 - 1564) também procurou equilibrar o papel do poder eclesiástico com o poder civil em sua obra Sobre o Governo Civil.

O nacionalismo do cristianismo alemão não era apenas por parte dos protestantes, mas, também, por parte dos católicos. Durante o Segundo Reich, o Kaiser era visto como um representante de Deus que governava a nação conforme a Sua vontade e, na República de Weimar, alguns sacerdotes católicos ameaçavam negar os sacramentos a quem apoiasse o regime político liberal ${ }^{85}$.

A responsabilidade pela Alemanha era tanto de protestantes quanto de católicos. Como foi dito, ambos somavam $95 \%$ da população do país quando Hitler ascendeu ao poder em 1933. Do lado católico também foram cometidas falhas neste processo, houve os que se comprometeram com o regime nazista e os que resistiram, assim como encontramos do lado protestante.

Quando o nazismo chegou ao poder na Alemanha o papa era Pio XI (1922 1938). Foi apenas nesta época, especificamente em 1928 que o catolicismo condenou o anti-semitismo, mesmo assim na liturgia das missas próximas à páscoa, os padres continuavam orando para que Deus perdoasse os pérfidos judeus ainda sustentando a cultura de que os judeus seriam os responsáveis pela morte de Jesus. Esta expressão só foi retirada em 1959 na primeira missa de páscoa do pontificado de João XXIII $(1958-1963)^{86}$.

Hitler foi eleito chanceler da Alemanha em 1933 com os votos dos católicos e do Partido de Centro. Parece que a igreja temia pela ameaça dos comunistas ateus que ameaçavam dominar a Alemanha assim como já estavam fazendo em várias partes do planeta. $\mathrm{O}$ medo do ateísmo militante dos comunistas e a repulsa em relação ao liberalismo laicista fizeram com que a igreja se aproximasse de um movimento nacionalista de direita, e visse na assinatura de uma concordata entre o Vaticano e o Terceiro Reich um mal menor que as outras duas tendências. A

${ }^{85}$ LUTZER, Erwin. o.c. p. 134.

${ }^{86}$ Disponível em http://www.jcrelations.net/OHolocaustoeaConscienciaCrista. Acessado em 7/09/2013, às 22:34. 
concordata parecia que protegeria a igreja politicamente e lhe garantiria autonomia.

Em 1937, depois das Leis de Nuremberg de 1935, que punha fim aos direitos de cidadãos alemães dos judeus, o Papa Pio XI escreveu uma encíclica que condenava o regime nazista. Esta encíclica foi lida em todas as igrejas católicas da Alemanha e o regime de Hitler reagiu com a interpretação de que a concordata fora rompida e retaliou a igreja no país ${ }^{87}$.

Vale lembrar que não foi apenas na Alemanha que o catolicismo se relacionou com o nacionalismo. $\mathrm{Na}$ Itália o pontífice teve de conciliar a igreja com o Estado fascista de Benito Mussolini. A atual composição do Estado do Vaticano é consequência da Concordata de Latrão de 1929 assinada pelo Papa Pio XI e pelo ditador italiano. Na Reunificação Italiana de 1870, que inclusive interrompeu o Concílio Vaticano I, foi declarado o fim dos Estados Pontifícios que já duravam mais de mil anos. Os papas até Pio XI jamais admitiram esta perda. A Concordata de Latrão pôs fim a esta insistência. O papa reconhecia o fim dos Estados Pontifícios em troca, recebia a autonomia do Estado do Vaticano e seu reconhecimento como chefe desse Estado e mais uma compensação de US\$ 90 milhões de dólares, o que foi muito útil para tirar as contas da igreja do vermelho.

Em 1939, o Papa Pio XI morreu e foi eleito o diplomata Dom Eugenio Pacelli como seu sucessor. Pacelli adotou o nome de Pio XII (1939 - 1958). Naturalmente muitos esperavam que o Papa Pio XII fosse dar continuidade a política de seu antecessor, e que fosse usar todo o seu poder de opinião e de mobilização para se opor ao nazismo, mas a posição considerada por muitos como neutra de Pio XII frustrou os opositores de Hitler.

Pacelli antes de ser papa trabalhou como núncio apostólico na Alemanha até se tornar Secretário de Estado do Vaticano em 1930. Foi ele o mediador da concordata entre o Vaticano e a Alemanha nazista e, disse que na ocasião não tinha escolhas de não assinar o trato. É curioso citar que Pacelli, enquanto Secretário de Estado, exigiu retratação do cardeal Theodor Innitzer (1875 - 1955) de Viena, quando este apoiou a anexação da Áustria à Alemanha hitlerista.

${ }^{87}$ Idem. 
Como papa, Pio XII não fez nenhuma condenação pública do nazismo e nenhuma condenação do anti-semitismo, o que se tivesse ocorrido talvez diminuísse o sofrimento dos judeus, embora tenha contribuído para a fuga de centenas de milhares de judeus ${ }^{88}$. Alguns historiadores afirmam que Pio XII arquivou a encíclica em que o antecessor condenava o fascismo italiano e que não teve tempo de publicar em vida. Era a encíclica Humani Generis Unitas, que Pio XI teria encomendado e não teve tempo de vê-la publicada, esta encíclica foi esquecida e apenas João XXIII fez alguma menção a ela durante o seu pontificado sem revelar todo o seu conteúdo ${ }^{89}$.

Hans Küng (1928 - ) classificou Pio XII como um homem comprometido com elementos medievais, contrarreformatórios e antimodernos. Considerou-o um papa que estranhava os direitos humanos e teve dificuldades com a democracia, que era um líder autoritário e obcecado pelo medo do comunismo. Pio XII proibiu o exercício do magistério de grandes teólogos de sua época como Teilhard de Chardin (1881 - 1955), Henri de Lubac (1896 - 1991) e Yves Congar (1904 1995) e foi contra a criação do Estado Judeu de Israel em 1948 ao mesmo tempo em que nunca condenou o nazismo e antissemitismo publicamente e que se esquivou de excomungar os criminosos nazistas que eram católicos ${ }^{90}$

Pio XII estava convencido de que não podia publicamente fazer muito, pois temia, que posicionamentos seus como papa pudessem gerar sérias retaliações do regime nazista contra a população e o clero católico nos países dominados pelo nacional-socialismo. É fato que nunca houve uma excomunhão formal de Adolf Hitler que se declarava católico, ainda que a obra $O$ Mito do Século XX de Alfred Rosemberg (1893 - 1946), tenha sido incluída no índex. Rosemberg foi um dos principais teóricos do nazismo.

Mesmo em meio à suposta omissão do pontífice, houve vários clérigos católicos que lutaram contra o nazismo. Muitos sofreram sérias retaliações, como na anexação dos Países Baixos pela Alemanha em que os bispos da região protestaram publicamente contra a prisão de vários sacerdotes e, este novo

${ }^{88}$ Idem.

89 PASSELECQ,Georges e SUCHECKY,Bernard. A Encíclica Escondida de Pio XI. Petrópolis: Editora Vozes, 1998. p. 17.

${ }^{90}$ KÜNG, Hans. A Igreja tem Salvação? São Paulo: Editora Paulus, 2012. p. 168-171. 
protesto levou à prisão de mais milhares de pessoas ${ }^{91}$. Estas represálias ajudaram o Papa Pio XII a ter uma postura ainda mais contida, pois temia que as represálias fossem maiores com um protesto feito pelo próprio papa.

Sem dúvida alguma a relação entre cristianismo e nazismo foi uma das páginas tristes da história da humanidade. Entre os anos 1933 a 1939, quando o nazismo ja governava a Alemanha, o apoio de muitos católicos e protestantes foi praticamente irrestrito. Depois que a Segunda Guerra começou e o regime de Hitler mostrou sua face bélica, houve reações por parte de cristãos, mas já era tarde demais e muitos já estavam envolvidos demais para reagirem. Porém, desde antes de Hitler chegar ao poder houve grupos que militaram na oposição de todo aquele movimento. Karl Barth observou o nazismo atentamente desde os seus primeiros momentos e sempre foi uma voz profética naquele contexto e não poupou esforços na luta pela democracia e pela humanidade.

\section{2 Karl Barth durante o Nazismo (1933 - 1945)}

Karl Barth lutou arduamente durante o regime nazista na Alemanha, país onde vivia quando Hitler chegou ao poder e onde permaneceu até a sua extradição em 1935, como represálias ao seu engajamento político-social. Mesmo quando retornou ao seu país de origem, Barth continuou lutando e usou sua inteligência, seus artigos, suas palestras. Ou seja, lutou com tudo o que dispunha, pois acreditava que a fé em Jesus Cristo o compelia a se engajar em prol do ser humano, criado e amado por Deus. A fé em Jesus fez Barth lutar pelo homem por quem Jesus se entregou e salvou.

Barth teve de enfrentar sérios problemas devido ao seu posicionamento como a suspensão de seu título de doutor pela Universidade de Munique, sua aposentadoria compulsória e sua expulsão da Alemanha. Se Barth não fosse suíço talvez teria corrido sérios riscos de morte, assim como aconteceu com Dietrich Bonhoeffer e com muitos outros líderes cristãos como Martin Niemoller que terminaram nos campos de concentração, mesmo que este último não tenho morrido na prisão.

91 Disponível em http://www.jcrelations.net/OHolocaustoeaConscienciaCrista. Acessado em 7/09/2013, às 10:46. 
Foi o momento mais intenso em sua luta político-social, até porque o momento era urgente e precisava de todos os esforços possíveis. Barth fez parte da Igreja Confessional e sempre esteve na resistência ao nazismo, o grupo do qual Barth fez parte muitas vezes teve de lutar sozinho e às vezes contra o próprio cristianismo alemão.

\subsection{1}

\section{Sua luta!}

Certamente não é tarefa das mais fáceis analisar o posicionamento dos cristãos (sejam eles católicos e protestantes) na Alemanha do início da década de 30. O contexto político, econômico e social daquele período era muito complexo. Como analisado, era um momento de humilhação imposta pelo Tratado de Versalhes de 1919 como resposta à Primeira Guerra, um período político diferente representado pela República de Weimar, que se mostrou vulnerável, marcado por elevados índices de desemprego, desvalorização da moeda nacional e muita pobreza.

Hitler subiu ao poder com um discurso ultranacionalista e em pouco tempo alcançou resultados extraordinários. Com isso um clima de enorme euforia tomou conta do povo alemão, que passou a acreditar que aquele novo momento era proporcionado por Deus com o objetivo de levá-los de volta ao seu passado de glórias.

No cristianismo a situação era ainda mais intensa, pois além de tudo isso se somava a aura messiânica formada ao redor do fuher e todo ideal teórico de defesa e amor pelo Estado como sendo oferta dada ao próprio Deus. Reagir num momento como esses não era tarefa fácil, sob nenhum aspecto. Era necessária uma fé madura e firme, iluminada e amparada pelas Escrituras, além de um profundo conhecimento político-social daquele contexto. Karl Barth sempre ensinou que seus alunos precisavam ter a Bíblia numa das mãos e os jornais na outra. Desta maneira teriam convicção de sua fé e ciência do mundo ao seu redor, e poderiam propor uma fé engajada e não alienada.

Também se deve lembrar que a luta contra o nazismo por parte do cristianismo, principalmente antes de começar a Segunda Guerra em 1939, foi ainda mais difícil porque as alternativas ao nazismo eram o secularismo liberal 
presente na República de Weimar e o Comunismo ateísta que crescia em toda a Europa. Diante desse quadro a igreja teve medo e muitos cristãos viram no nazismo (nacionalista e teoricamente cristão) o mal menor para governar o seu país.

Desde quando Hitler subiu ao poder em 1933, muitos líderes cristãos tentaram uma fórmula que unisse o cristianismo com o nazismo e, desde a mesma época teólogos como Karl Barth, perceberam o perigo contido nesta tentativa. Barth desde o começo se opôs com veemência ao processo de hitlerização da igreja.

Deve-se citar que o engajamento político-social não era novidade para Barth. Quando foi pastor em Safenwil na Suíça, ele lutou pelos trabalhadores de sua paróquia, fossem homens ou mulheres. Naquele período, Barth se filiou ao Partido Social Democrata, em 1915, e desde então militou no Socialismo Cristão.

Barth acreditava que, quando o homem recebe a Palavra de Deus através de sua revelação em Jesus Cristo, é revestido de uma nova dignidade. Para Barth a primeira preocupação na Alemanha nazista era teológica e não apenas política. Barth não foi dualista em seu discurso e práticas de fé, como muitos cristãos alemães o foram. Era comum um cristão alemão cantar hinos de louvor a Jesus no domingo na igreja, e na segunda-feira desejar a eliminação dos judeus de seu território, por exemplo.

Barth usou seu potencial teológico para resistir aos interesses nazistas em relação à teologia cristã. Os nazistas queriam alijar da teologia qualquer referência à fraqueza, à misericórdia e ao perdão, porque eram considerados incompatíveis com a força apresentada pelo novo sistema político. Num discurso, Adolf Hitler chegou a dizer que o interessante para o povo alemão era saber se teriam uma fé cristã judaica com moral frágil com seu discurso de compaixão ou se teriam uma fé forte, heróica em Deus e no seu próprio povo, em seu próprio destino e seu próprio sangue (o sangue ariano considerado o superior) ${ }^{92}$.

Diante do discurso de poder e de etnocentrismo de Hitler, Karl Barth apresentou uma imagem de Deus bem diferente da proposta pelo nazismo, a imagem de um Deus que embora fosse glorioso e poderoso não se satisfez em viver só nos céus e preferiu se fazer fraco e limitado para ter comunhão com o ser

92 NASCIMENTO, André dos Santos Falcão. Nazismo e Cristianismo. São Paulo: Fonte Editorial, 2012. p. 55. 
humano ${ }^{93}$. Um Deus que nos ensina a tomar as cargas uns dos outros justamente porque ele fez isso por nós primeiro. Barth via em Jesus a imagem de um Deus humilde que se auto-humilhou e encarnou, não como um tirano ou um líder majestoso, mas como um servo, um Deus que abriu mão de sua glória para servir. Certamente não era a imagem de um Deus humilde e servo que Hitler queria ter na igreja alemã, pois o seu discurso de superioridade racial não combinava com o serviço divino.

Para Barth, Jesus Cristo era o verdadeiro Deus e o verdadeiro homem. O teólogo entendia a onipotência de Deus como a liberdade de tornar-se fraco e de caminhar pela via que conduz à crucificação. Deus demonstrou que é um ser verdadeiramente poderoso porque ousou tornar-se fraco e destituído, em vez de manter-se entronizado em inalcançáveis altitudes, como faria o homem caso pudesse. Deus desce até o homem e ao invés de exigir do homem serviço, Ele se apresenta como alguém que serve ${ }^{94}$.

Ainda em 1933 quando a disputa para eleger o Bispo do Reich tomou conta da igreja protestante alemã, Barth expressou simpatia pelo Pastor Bodelschwingh, embora essa simpatia pessoal não o impedisse de criticá-lo quando considerou que lhe faltou firmeza teológica em algumas questões. Na noite em que Bodelschwingh foi demitido, Barth escreveu seu manifesto Theologische Existenz heute! (Existência Teológica hoje!).

Em seu manifesto, escrito quando morava e trabalhava em Bonn, Barth conclamou pregadores e doutores a ensinarem e a proclamarem a Palavra de Deus, e que esta era a maior urgência que o mundo possuía e esta tarefa deveria ser feita custe o que custasse ${ }^{95}$. Para Barth era papel dos pregadores e professores servirem à Palavra de Deus quer fosse na Igreja, quer fosse no mundo e nenhum inimigo poderia se opor ao cumprimento desta missão.

Barth alertou os teólogos que estavam se envolvendo com a nazificação da igreja alemã a que eles não perdessem a existência teológica e, insistiu que a igreja é do Espírito Santo e, portanto deve trazer esperança às loucuras e fraquezas humanas e proporcionar-lhes algo festivo. Barth não aceitou a legitimação de um Estado-deus ou de um Estado-igreja, como era o intuito do nazismo sendo um

\footnotetext{
${ }^{93}$ HORDERN, William. o.c. p. 174.

${ }^{94}$ Ibid, pg. 173.

${ }^{95}$ BARTH, Karl. Existência Teológica Hoje in: ALTMANN, Walter (Org.). o.c. p. 142.
} 
Estado totalitário e visando ter controle sobre Deus e Sua Revelação ${ }^{96}$. Para Barth a Igreja era um lugar que tinha o testemunho bíblico como limite, no qual Cristo é proclamado e sentido sob a direção deste testemunho, é um lugar dirigido por Cristo e no qual este testemunho tem direito e poder, vitória e soberania ${ }^{97}$.

Hitler entendeu que o cristianismo alemão era um ponto importante daquela sociedade e precisava estar alinhado com seus interesses. Logo no primeiro ano em que o nazismo assumiu o poder, foi aprovada a Constituição da Igreja Evangélica Alemã, os chamados Cristãos Alemães. Essa aprovação pelo Reichstag aconteceu em 14 de julho de 1933. Em oito dias e na véspera das eleições eclesiásticas gerais, Barth reagiu e escreveu o artigo chamado Para a Liberdade do Evangelho no segundo caderno da revista Theologische Existenz heute! Para o teólogo, a igreja precisava continuar manifestando sua confiança na liberdade do Evangelho, pois se a igreja admitisse outra revelação que não a de Deus e outro senhorio que não o de Cristo, ela estaria assumindo que o Evangelho não era mais livre. Portanto, deixaria de ser evangélica e deixaria de ser igreja ${ }^{98}$.

O ano de 1933 foi intenso e decisivo. Foi exigido que todo pastor e professor de teologia assinasse um documento de apoio incondicional ao füher. Além disso, Hitler lutou para promover uma desjudaização do cristianismo, Jesus deixou de ser apresentado como um judeu e passou a ser apresentado como um ariano. É claro que diante de tudo isso, Karl Barth não ficou calado, ele defendeu com a coragem de poucos o judaísmo e o povo judeu, rejeitou assinar o juramento de fidelidade a Hitler e reafirmou a sua convicção de que apenas Cristo era o Senhor de todas as coisas.

Como teólogo, Barth sempre rejeitou a tentativa dualista que a teologia nazista queria impor ao cristianismo da Alemanha, como expresso na conversa que Hitler teve com o pastor Martin Niemoller onde o füher disse ao pastor que o seu papel era cuidar dos afazeres da igreja e a tarefa de cuidar do povo alemão cabia ao Reich e, apenas a ele. Barth era claro quando afirmava que não havia nenhuma esfera da vida humana que não pertencesse a Cristo, pois Cristo nos chamou para o discipulado e isso abrange a nossa vida como um todo ${ }^{99}$.

${ }^{96}$ CORNU, Daniel. o.c. p. 25.

${ }^{97}$ BARTH, Karl. Credo - Comentários ao Credo Apostólico. São Paulo: Fonte Editorial, 2005. p. 189.

${ }_{98}$ CORNU, Daniel. o.c. p. 32.

${ }^{99}$ NASCIMENTO, André dos Santos Falcão. o.c. p. 69. 
No início de 1934, o cerco se fechou ainda mais para Barth e outros líderes que se recusaram jurar fidelidade a Hitler. Ludwig Müller, o Bispo do Reich, proibiu a participação dos pastores na política da igreja, vendo a desobediência diante dessa lei como uma infração à disciplina eclesiástica, prevendo inclusive a suspensão de quem se recusasse a obedecer. Mesmo assim, Barth prosseguiu em sua luta. Ainda em 1934, teve sua licença de professor cassada, e um processo disciplinar foi aberto contra ele. Em dezembro, Barth foi demitido do serviço público. Em 1935 sua demissão foi revogada e recebeu uma pesada multa em seus salários anuais. Em junho do mesmo ano, Barth foi aposentado compulsoriamente pelo Ministro de Cultura da Prússia. Três dias depois desta decisão, Barth retornou ao seu país de origem aceitando ao convite para trabalhar na Universidade de Basiléia, de onde continuou com seu posicionamento até o fim.

Em 1938, às vésperas da Guerra, aconteceu o Anchluss, que foi a anexação da Áustria pelo regime de Hitler. Logo a seguir, regiões germânicas da Tchecoslováquia também foram anexadas especialmente os Sudetos. Neste período, Barth já morava na Basiléia na Suíça, mas isso não o impediu de se posicionar. O teólogo escreveu uma carta para o pastor e teólogo tcheco Josef Luk1 Hromádka (1889 - 1969). No escrito, Barth incentivou os cristãos tchecos a lutarem contra o nazismo alemão que invadira o país vizinho e disse que a consciência do Evangelho autorizava o cristão a se opor ao nacional-socialismo, ainda que fosse o caso de uma resistência armada ${ }^{100}$.

A carta que Barth enviou a Hromádka teve grande repercussão. Alguns inclusive, o acusaram de ter sacrificado sua teologia em nome de seu engajamento político-social. Tal acusação certamente era exagerada. O certo é que Barth lutou política e socialmente de modo visceral, não apenas no período nazista, mas desde antes em Safenwil e depois do término da Segunda Guerra. Barth nunca fez separação entre a sua fé e a sua prática, diante do nazismo alemão das décadas de 30 e 40. Diante de outros casos, Barth manifestava o aspecto prático de sua teologia, pois ele achava hipocrisia que os cristãos orassem por um Estado justo e não fizessem nada para torná-lo de fato justo.

Em sua carta ao pastor Hromádka, Barth falou sobre a situação da população de países europeus que estavam vivendo debaixo de severas ditaduras,

${ }^{100}$ CORNU, Daniel. o.c. p. 82 . 
como nos casos de Alemanha e da Tchecoslováquia. Neste escrito Barth disse que às igrejas nesses lugares restavam apenas duas alternativas: ou a submissão à ditadura, o que a lançaria no ridículo diante de Deus e do mundo, ou lutar pela ordem e pela liberdade na Europa ainda que isso lhe expusesse à destruição por parte da ditadura. Barth era firme quando afirmava que a única política cabível à igreja era a da ordem e da liberdade ${ }^{101}$.

Para Barth, a guerra era preferível à ditadura, pois não pode existir paz autêntica que não em um Estado justo. O teólogo denunciou a política do nazismo quando afirmou que aquele Estado significava um triste golpe no Estado justo, pois, o nazismo não servia a Deus, nem ao bem, nem aos necessitados e nem garantia um lugar para a livre proclamação do Evangelho, o nazismo destruía a ordem, a liberdade e o direito.

O Estado alemão nazista não era um Estado legítimo, pois sufocou a imprensa, fraudou eleições, gerou um profundo clima de terror não apenas na Alemanha, mas também nos países que dominou, criou um clima de insegurança com prisões arbitrárias, execuções sumárias, enfim, uma constante agressão à democracia e aos direitos humanos. Diante disso, a igreja, segundo Barth tinha, não apenas o direito como o dever de se opor com veemência ao Estado que é mau, exige-se da igreja uma posição política.

Barth conclamou a igreja a orar pela destruição do nazismo e pela restauração e conservação do Estado justo ${ }^{102}$. Barth era um teólogo que entendia a fé de modo integral e não se conformava com a tentativa dualista que a política do Reich tentava impor ao cristianismo alemão. O engajamento político-social fazia parte da vida do teólogo. Ele não apenas ensinava a orar para que houvesse justiça social e política, como ele próprio dedicava-se a orar por isso, mas não de forma alienada ou isolada, essa prática era uma consequência de uma vida envolvida na luta por justiça e democracia. O teólogo se preocupava, em suas orações, com a realidade de países que viviam debaixo de ditaduras, conforme revela algumas orações feitas por ele que foram publicadas em uma obra específica ${ }^{103}$.

Como já apontado, para Karl Barth o engajamento político-social não era algo isolado, mas sim uma consequência de sua fé e de sua herança teológica.

${ }^{101}$ Ibid, p. 85 .

${ }^{102}$ Ibid, p. 88 . 30 .

${ }^{103}$ BARTH, Karl. Senhor, ouve a nossa oração! São Leopoldo: Editora Sinodal, 2013. p. 
Barth apontou para a Reforma Protestante, da qual era herdeiro e, apelou para que todos os protestantes da Alemanha, igualmente herdeiros da Reforma, lembrassem que o movimento do século XVI não foi um ato de poetas, filósofos ou reis, mas de homens de fé que tomaram a decisão de defender verdades bíblicas que há muito não mais se ouvia. Para Barth, aqueles que se decidiram pela fé cristã não tinham mais tempo para desviar-se dela, porque decidir-se pela fé cristã é decidirse por Deus como Senhor da pessoa humana ${ }^{104}$.

Karl Barth entendia que lutar pelos oprimidos do sistema político, lutar por justiça e por democracia era algo inevitável para um cristão, pois a fé começa com a Revelação de Deus e essa Revelação é inseparável com o testemunho e a confissão. Como o próprio Barth propõe, a fé em Jesus Cristo, perfeita e plena Revelação de Deus, é vivida num campo de batalha e não num palco ou num gabinete pastoral ${ }^{105}$. Confessar a fé é obedecer à revelação de Deus e essa revelação divina é dirigida para o ser humano em sua totalidade. $\mathrm{O}$ engajamento político-social para Barth era uma questão de santidade, uma questão de fé e de obediência à Revelação de Deus e espera que a Sua igreja lute por aqueles pelos quais Jesus se entregou.

Barth insistia que a igreja deveria ter um papel apolítico (apartidário), pois ela foi chamada para pregar o Evangelho e testemunhar de sua fé, mas isso não a isenta de uma atuação verdadeiramente política como testemunha da justiça e do amor de Deus. O papel da igreja não é fazer política com o intuito de governar, mas ela pode e deve testemunhar, diante dos povos e dos governos, que a política é um serviço de Deus e que a justiça e a liberdade são dons de Deus ${ }^{106}$.

O teólogo da Basiléia distinguia o Estado legítimo do Estado ilegítimo. No caso, o Terceiro Reich era um Estado ilegítimo, pois não estava do lado do necessitado e do explorado, pelo contrário, era o próprio Estado quem contribuía para a exploração e perda de direitos democráticos dos cidadãos. O papel do Estado era promover a liberdade.

Barth chamou de diabólica a competição de interesses que existem diante de nós e mesmo a guerra mundial. Repudiava os antagonismos entre classes e a depravação moral que existia dentro dessas pirâmides sociais, além de denunciar a

\footnotetext{
${ }^{104}$ BARTH, Karl. Reforma é Decisão in: ALTMANN, Walter (Org.). o.c. p. 172.

105 BARTH, Karl. Revelação, Igreja, Teologia in: ALTMANN, Walter (Org.). o.c. p. 181.

${ }^{106}$ CORNU, Daniel. o.c. p. 97.
} 
tirania econômica que ficava acima e os espíritos escravizados que ficavam abaixo. Barth disse que na sociedade havia um sentimento que tentava o ser humano a se conformar com a injustiça, mas quando nos voltamos para Deus encontramos Sua vontade que é justa ${ }^{107}$.

O teólogo que ganhou notoriedade em 1919 quando lançou o seu comentário da Carta aos Romanos, teve de ver o texto de Romanos 13;1-2 sendo muito explorado pela mídia nazista como uma prova bíblica de que o Estado deveria ser obedecido e honrado a qualquer custo. Para o teólogo, o ser humano deveria obedecer a qualquer custo apenas à vontade de Deus, e não tinha o direito de colocar impedimentos a que Sua vontade fosse obedecida. Já a obediência ao Estado dependia de alguns fatores: esta obediência não pode ser cega e deve ser posterior à obediência a Deus, pois Ele é o Senhor da Igreja e do Estado. Diante de um Estado totalitário, o cristão não apenas deve desobedecer como deve se opor com veemência, justamente por causa de sua obediência a Deus.

O Estado deveria ser uma ferramenta nas mãos de Deus para exercer o direito e a justiça para o bem-estar de todas as pessoas. Um Estado totalitário é um Estado blasfemo e idólatra, pois exige culto ao seu líder e luta contra os santos com a finalidade de conquistar o mundo ${ }^{108}$.

Certamente o período mais triste da história do nazismo e, possivelmente na história da humanidade, foi o período da Segunda Guerra Mundial (1939 - 1945) que Barth viveu muito de perto e com muita lucidez. Neste trágico período o engajamento de Barth continuou intenso. Neste momento o teólogo morava e trabalhava na Suíça, e de lá, escreveu várias cartas às igrejas de países submetidos à ocupação nazista, analisou a própria situação política da Suíça naquele contexto. Barth enviou cartas para os cristãos da França, da Grã-Bretanha, da Noruega e dos Países Baixos, ou seja, ele não se calou mesmo no momento de maior perigo.

Em relação à guerra, Barth também teve a clareza de analisar as consequências do Tratado de Versalhes de 1919 para o que estava acontecendo. Segundo ele, as democracias europeias também tinham responsabilidades para com a Europa marcada pelo hitlerismo, pois ao fim da Primeira Guerra, as potências impuseram um tratado de paz duro e humilhante para os alemães. Se

\footnotetext{
${ }^{107}$ BARTH, Karl. A Palavra de Deus e A Palavra do Homem. São Paulo: Fonte Editorial, 2004. p. 10

${ }^{108}$ FILHO, Manoel Bernardino de Santana. o.c. p. 149.
} 
tivessem optado por uma paz razoável, o hitlerismo talvez não passaria de uma seita política do interior da Alemanha, e não uma ameaça para toda a Europa ${ }^{109}$.

O teólogo suíço manteve firme as suas convicções de fé mesmo durante a guerra, e acreditava que Deus estaria no comando daqueles conflitos porque Jesus ressurgiu e venceu as forças do mal e, portanto Deus ainda exercia soberania sobre a história. Barth destaca a posição política que os cristãos deveriam adotar em nome de uma fé comprometida com o Evangelho de Jesus Cristo: defender o direito contra a ilegalidade, a justiça contra a injustiça, a liberdade contra a opressão, a ordem contra a anarquia, a humanidade contra a desumanidade, a democracia contra a ditadura, ou no caso, a Suíça contra a Alemanha nazista ${ }^{110}$.

No início de 1945 a Segunda Guerra Mundial estava caminhando para a sua conclusão e o Terceiro Reich, para a queda. Os países ora dominados pelos alemães foram reconquistando a sua liberdade e a estabilidade vai retornando à Europa. No dia 30 de abril, Hitler se suicidou e dois dias depois a capital Berlim foi dominada. No dia 7 de maio de 1945 foi assinada a capitulação geral do exército alemão. Diante do fim da guerra, Barth alertou sobre as decisões que deveriam ser tomadas dali pra frente, ele pediu que fosse dada uma paz razoável que não esmagasse a Alemanha, mas que lhe fosse concedida uma chance honesta e assim se evitassem os erros na guerra anterior que gerou trágicas consequências. Barth exortou os teólogos alemães a assumirem uma posição de confissão pelos seus pecados e uma postura de humilhação perante tudo o que passou. Assim encontrariam em Deus a misericórdia e o amor para um recomeço.

Mesmo diante disso tudo é bom dizer que Karl Barth não sossegou com o fim da Segunda Guerra, ele manteve-se engajado no mundo posterior ao do nazismo. No mundo bipolarizado, dividido entre capitalistas e comunistas, a luta continuava!

${ }^{109}$ CORNU, Daniel. o.c. p. 94.

${ }^{110}$ Ibid, p. 101. 


\section{2 .2}

\section{A Declaração de Barmen e a Igreja Confessante}

Mesmo diante de um momento tão difícil como foi a ascensão de Hitler e do nazismo na Alemanha no início de 1933 e tudo o que se desenrolou a partir daí até o fim da Segunda Guerra Mundial em 1945. Além disso a apatia e a omissão dos cristãos do país frente aos acontecimentos que mudariam o mundo para sempre, houve um grupo de resistência ao nazismo alemão desde o início de sua caminhada de destruição e de horror. Um grupo não muito grande do ponto de vista numérico, não poderoso do ponto de vista político, que teve de atuar na clandestinidade, mas que foi fiel aos seus ideais de cristianismo e lutou até o fim contra o nazismo de Hitler e suas pretensões de dominar a igreja alemã.

Em julho de 1933, como foi visto, o Reichstag reconheceu a Igreja Evangélica Alemã, a igreja oficial do regime nazista que procurou aliar o cristianismo com o nazismo. Em setembro de 1933, as eleições eclesiásticas do país elegeram pessoas ligadas à igreja oficial para 75\% dos cargos disponíveis e, ainda elegeu Ludwig Müller como Bispo do Reich após a demissão do Pastor Bodelschwingh.

Ainda em 1933, Karl Barth e Eduard Thurneysen se desligaram oficialmente da revista teológica Zwischen den Zeiten por considerarem que suas publicações, especialmente de Friedrich Gogarten (1887 - 1967) eram essencialmente alinhadas com a tese dos Cristãos Alemães, de confundirem a lei de Deus com a lei do Terceiro Reich. Com essa decisão de Barth e Thurneysen, que ajudaram a fundar a revista, suas publicações foram encerradas pelo diretor.

Em 1933 houve o Sínodo Pardo, que estabeleceu um sentimento antissemita na igreja alemã. Diante do antissemitismo do Sínodo Pardo, foi criada a Liga Pastoral de Emergência, em setembro de 1933. Esta Liga foi criada por Dietrich Bonhoeffer e Martin Niemoller e tinha como objetivo combater a cláusula ariana e adotar uma postura contrária à interferência do nazismo na igreja. Podemos dizer que a Liga Pastoral de Emergência foi um protótipo do que seria a Igreja Confessante.

Nos 3 e 4 de janeiro de 1934 um sínodo não oficial se reuniu na cidade de Barmen para discutir exatamente qual seria a posição da comunidade cristã diante da política nazista que já governava o país. Eram representadas no encontro 167 
igrejas reformadas por 320 pastores e conselheiros sinodais. O principal objetivo deste sínodo era de estudar a confissão de fé, criando assim, um ambiente de reflexão eclesiológica sobre a verdadeira função da igreja.

Na reunião de Barmen, Barth fez duas exposições: Declaração a respeito de uma justa compreensão das confissões de fé dos Reformadores na Igreja Evangélica alemã contemporânea e Vontade de Deus e desejos dos homens. Na primeira exposição, Barth refletiu sobre a problemática contida na posição dos Cristãos Alemães em se submeterem ao nazismo, na segunda exposição, ele conclamou os líderes presentes a não perderem a identidade evangélica da igreja alemã.

Barth usou o exemplo dos Reformadores e as dificuldades que eles tiveram de enfrentar em sua época e convocou os cristãos a se unirem em torno de uma mesma declaração de fé, que não seria um ensinamento doutrinal completo, mas um ato concreto de posicionamento frente a um momento histórico específico.

O sínodo de Barmen é uma resposta de diversas igrejas contra a política eclesiástica arbitrária adotada por Ludwig Müller, Bispo do Reich, que no mesmo dia do encontro em Barmen decretou que toda participação dos pastores na política alemã seria vista como ato de indisciplina eclesiástica suscetível à punição.

O grupo denominado de Igreja Confessante, da qual fizeram parte pessoas como Barth, Dietrich Bonhoeffer, Martin Niemoller, Eduard Thurneysen, dentre outros, não cedeu mesmo diante das ameaças de Müller, e declararam que importava obedecer antes a Deus que aos homens ${ }^{111}$.

As tensões ficaram tão acirradas que no dia 25 de janeiro de 1934, o próprio Hitler se reuniu com um grupo de representantes da Igreja Confessante a fim de chegar a um acordo, o que não aconteceu. Um telefonema do pastor Niemoller onde ele falava livremente sobre as relações de Hitler e de Hindenburg foi interceptado, e o conteúdo da fala levou Hitler à ira.

O encontro do início de janeiro de 1934 não foi o único da Igreja Confessante. Em janeiro as bases teológicas do movimento em oposição aos cristãos alemães foram estabelecidas. Nos dias 18 e 19 de fevereiro daquele mesmo ano, foi realizado um segundo encontro, desta vez, reuniu não apenas

${ }^{111}$ Cf. At 5,29 
líderes ligados às igrejas reformadas, mas também as igrejas luteranas e unidas da Renânia. No segundo encontro de fevereiro, as teses propostas no primeiro encontro foram retomadas e a liderança da Igreja do Reich não foi reconhecida.

Em seguida, aconteceu a adesão da Igreja Unida da Prússia, com seus quase 20 milhões de membros, ao movimento iniciado em Barmen. Outros sínodos aconteceram por todo o país como consequência das reuniões de janeiro e fevereiro, até que um Sínodo Geral foi realizado em Barmen nos dias 29 a 31 de maio de 1934.

Os participantes da Igreja Confessante não se desligaram juridicamente da Igreja Alemã, a diferença era que os confessantes reconheciam a autoridade única de Jesus Cristo sobre a igreja, rejeitando a autoridade eclesiástica estabelecida pelo Terceiro Reich ${ }^{112}$.

Para Karl Barth confessar a fé queria dizer levar o Evangelho ao encontro com a realidade, fosse ela eclesiástica, teológica e espiritual, mas também, social, cultural, econômica e política. Barth disse que os engajados na Igreja Confessante seriam mudos como carpas se elaborassem uma declaração de fé que nada tivesse a dizer sobre o Estado totalitário. Para Barth, o Estado não poderia se apropriar do homem em sua totalidade, não poderia querer definir a forma e a mensagem da igreja.

A Igreja Confessante, em princípio, não tinha o interesse de se opor politicamente a Hitler como chefe da nação, o que a Igreja nunca aceitou foi o totalitarismo do Estado e sua interferência direta na igreja. A Igreja Confessante não estava disposta a prestar um juramento de que obedeceria ao Estado incondicionalmente porque isso seria o mesmo que reconhecê-lo como Deus e, apenas a vontade de Deus deveria ser obedecida incondicionalmente.

A Declaração Teológica de Barmen, promulgada pelo Sínodo Geral de 29 a 31 de maio de 1934 era composta de seis artigos nos quais a Igreja Confessante se posicionava em relação à fé cristã e em relação aos acontecimentos políticoseclesiásticos daquele contexto. O texto da declaração de fé, que se tornou a base para a Igreja Confessante, foi elaborado por Karl Barth ${ }^{113}$.

Suas teses poderiam ser assim resumidas:

\footnotetext{
${ }^{112}$ CORNU, Daniel. o.c. p. 44 .

${ }^{113}$ Ibid, p. 43.
} 
I. Sustenta a ideia de que Jesus Cristo é a única Palavra de Deus na qual a Igreja deve confiar e obedecer na vida e na morte ${ }^{114}$. Neste primeiro ponto, a declaração rejeitava a pretensão nazista de que a Igreja deveria reconhecer, além e à parte da Palavra de Deus, outros poderes, personagens e acontecimentos como fontes de sua pregação e como revelação divina ${ }^{115}$. A Igreja Confessante reafirmou sua obediência incondicional apenas a Jesus Cristo;

II. Trata da reivindicação de Deus como o Senhor de toda a nossa existência. É a afirmação de que não existiria nenhuma área da vida humana que não pertencesse ao senhorio de Cristo ${ }^{116}$. A segunda tese refutava a proposta nazista de que existiriam algumas áreas da vida humana onde não precisaríamos da justificação e da misericórdia de Cristo. O Estado nazista queria convencer os cristãos alemães de que alguns aspectos da vida humana eram de ordem espiritual e outros aspectos que eram de ordem política;

III. Reafirma que a Igreja Cristã é a comunidade de irmãos na qual Jesus Cristo age como Senhor na Palavra e nos sacramentos através do Espírito Santo. Como a igreja é composta por pecadores que vivem num mundo pecador, os cristãos devem testemunhar a sua fé, sua obediência, sua mensagem, sua organização $^{117}$. Era uma repulsa a ideia que a igreja poderia substituir sua mensagem e organização de acordo com as respectivas convicções ideológicas e políticas;

IV. É uma declaração de humildade por parte da igreja de acordo com o ensinamento de Jesus. A igreja nesta tese está, politicamente, se posicionando contra o modo como o Estado estava exercendo domínio e poder na Alemanha. A declaração afirmava que a diversidade de funções na igreja não estabelecia o predomínio de uma sobre a outra, mas o ministério foi confiado a toda a

${ }^{114}$ A Primeira tese da Declaração Teológica de Barmen baseava-se nos textos de Jo 14;6 Eu sou o caminho, a verdade e a vida; ninguém vem ao Pai a não ser por mim e em Jo 10;1;9 Em verdade, em verdade vos digo: o que não entra pela porta no aprisco das ovelhas, mas sobe por outra parte, esse é ladrão e salteador...Eu sou a porta: se alguém entrar por mim será salvo.

${ }_{115}$ Disponível em www.luteranos.com.br/conteudo/a-declaracao-teologica-de-barmen. Acessado em 21/09/2013, às 18:34.

${ }^{116}$ A Segunda tese baseava-se no texto de 1Co 1;30 Mais vós sois dele em Cristo Jesus, o qual se nos tornou da parte de Deus sabedoria, justiça, santificação e redenção.

117 A Terceria tese baseava-se no texto de Ef 4;15-16 Mas, seguindo a verdade em amor, cresçamos em tudo naquele que é o cabeça, Cristo, de quem todo o corpo, bem ajustado $e$ consolidado, pelo auxílio de toda a junta, segundo a justa cooperação de cada parte, efetua seu próprio crescimento para a edificação de si mesmo em amor; 
comunidade de fé ${ }^{118}$. A Igreja Confessante não aceitava se desviar deste ministério dado pelo próprio Jesus e nem aceitava que lhe fosse dado líderes revestidos de poderes de mando, como significava a figura do Bispo do Reich;

V. Nesta tese, os confessantes deixavam claro que não tinham uma posição de rebeldia ou de insubordinação ao Estado, que eles não viam o Estado como um inimigo por si só, mas quando este queria ser um Estado totalitário e exige obediência incondicional. A tese aponta que o dever do Estado é de zelar pela justiça e paz num mundo ainda não redimido. A igreja reconhecia a necessidade do Estado e seu benefício para o ser humano, quando o mesmo cumpria o papel estabelecido por Deus, porém a igreja devia obediência incondicional apenas a Deus $^{119}$. A declaração rejeitava a ideia de que o Estado pudesse ultrapassar a sua missão específica. O Estado não pode querer assumir a missão da Igreja e a Igreja não pode ser resumida a apenas um órgão do Estado. Citava também a declaração que não é apenas o cidadão quem tem um compromisso com o Estado mas, o Estado também possui um compromisso com a missão que Deus lhe deu para o bem comum;

VI. Na sua última tese, o documento expressa o seu entendimento sobre a missão da Igreja que repousa na sua liberdade e que é a missão de transmitir ao ser humano a mensagem da livre graça de Deus. A declaração rejeitava a possibilidade da Igreja colocar a Palavra e a Obra de Deus à serviço de quaisquer desejos, propósitos e plano escolhidos arbitrariamente ${ }^{120}$.

É claro que depois destes acontecimentos a situação de Karl Barth na Alemanha nazista ficou muito comprometida. Inicialmente, ele foi proibido de falar em público, o que ele obedeceu apenas parcialmente. Recusou-se a obedecer a ordem de começar os seus cursos com a saudação nazista. Em novembro de 1934 se negou a jurar obediência incondicional do füher exigido a todos os funcionários públicos do país. Barth, assim como os cristãos primitivos, se negou a reconhecer a divindade do Estado e adorá-lo. O teólogo foi suspenso de suas atividades acadêmicas e deposto de sua cátedra em Bonn e como era estrangeiro

${ }^{118}$ A Quarta tese tem como base o texto de Mt 20;25-26 Sabeis que os governantes dos povos os dominam e que os maiorais exercem autoridade sobre eles. Não é assim entre vós; antes, quem quiser tornar-se grande entre vós, será esse o que vos sirva;

${ }_{119}$ Tese baseada no texto de 1Pe 2;17 Temei a Deus e honrai o rei;

${ }^{120}$ A ultima tese da Declaração de fé de Barmen baseava-se no texto de Mt 28;20 Eis que estou convosco todos os dias até a consumação dos séculos. E no texto de 2Tm 2;9 A Palavra de Deus não está algemada. 
foi deportado da Alemanha ainda em $1935^{121}$. Os demais pastores que assinaram a declaração de fé de Barmen, ou mesmo que possuíam uma cópia dela, também foram perseguidos pela Gestapo.

A Igreja Confessante realizou o seu segundo sínodo em Dahlen em 1934. Neste momento o clima de oposição ao nazismo, mesmo no campo político já era ainda mais acirrado e as denúncias de perseguição por parte do Reich já eram abertas. A tirania de Hitler já se manifestava de modo mais claro neste segundo momento.

Um terceiro sínodo foi realizado na cidade de Augsburg ${ }^{122}$. Neste evento a igreja optou por uma posição mais amena e menos combativa ao nazismo. Bonhoeffer e Niemoller escreveram aos pastores uma carta incentivando-os a não desanimarem e persistirem na luta contra o nazismo, porém a carta não teve grande impacto e o movimento perdeu parte de seu fôlego ${ }^{123}$.

\subsection{3}

\section{A questão dos judeus}

Uma das maiores chagas abertas no coração da humanidade foi o Holocausto que matou mais de 6 milhões de judeus nos campos de concentração. Diante de tamanho terror, parece até que ninguém falou nada naquela oportunidade, porém os integrantes da Igreja Confessante e, especialmente Karl Barth, já protestavam contra o antissemitismo praticado na Alemanha bem antes do Holocausto. As reuniões de Barmen trataram desse assunto e Barth foi uma voz profética a denunciar as terríveis perseguições que os judeus vinham sofrendo no país.

As perseguições aos judeus na Alemanha não foram inventadas por Hitler. É claro que foram intensificadas e chegaram ao auge no período nazista, mas já havia um triste histórico de antissemitismo no país. Muitos pesquisadores consideram como antissemitas algumas posições de Lutero. Em muitas áreas do próprio cristianismo se nutriu o pensamento de que os judeus eram os verdadeiros culpados pela morte de Jesus Cristo, o que historicamente criou um ambiente

${ }^{121}$ FILHO, Manoel Bernardino de Santana. o.c. p. 95.

${ }^{122}$ A cidade de Augsburg tinha relevância para os protestantes alemães. Foi nesta cidade que Lutero passou por uma Dieta no período da Reforma e foi lá também, que Felipe Melanchton apresentou a Confissão de Augsburg, a primeira confissão de fé reformada.

${ }^{123}$ LUTZER, Erwin. o.c. p. 172. 
hostil em relação aos judeus. Deve-se lembrar que até o fim da década de 50, na liturgia das missas de páscoa estava presente a oração pelos pérfidos judeus.

No período da igreja primitiva houve alguns problemas envolvendo cristãos e judeus. Dois exemplos que podemos citar são: as dificuldades causadas pelos judaizantes em algumas comunidades cristãs primitivas e a fuga de cristãos quando Jerusalém foi invadida pelos exércitos do general Tito $(39-81)$ e o templo foi destruído.

Já no período medieval, os judeus tiveram de se deslocar do Oriente Médio por causa das conquistas muçulmanas e foram morar na Europa cristã. Neste contexto, os judeus sofreram muitas hostilidades e foram massacrados em diversas oportunidades. Os judeus cresceram através do comércio. Foram acusados de se converterem ao cristianismo tendo como objetivo o acesso às atividades consideradas nobres naquela época ${ }^{124}$.

No período do Primeiro Reich, foi dada liberdade civil e religiosa para os judeus, o que acirrou a inveja e a insegurança em muitos cristãos que se sentiram ameaçados de perder importantes postos de emprego para os judeus, que até então não possuíam as mesmas condições socioeconômicas dos cristãos.

No Segundo Reich já se falava sobre uma batalha contra os judeus e estudiosos da época aplicavam o evolucionismo de Darwin aos seus estudos sociais e, desta forma consideravam os brancos como o topo da pirâmide da evolução social e os negros e judeus na base da mesma pirâmide ${ }^{125}$.

Alguns estudiosos afirmam que a Primeira Guerra Mundial acirrou o sentimento anti-judaico, pois em alguns fronts de batalha houve as acusações de que os judeus teriam deserdado levando muitos alemães a terem uma postura de aversão aos judeus por este fato.

Foi apenas na República de Weimar, que seguiu ideais liberais, que o casamento civil foi permitido, com isso, houve inúmeros casos de casamentos entre cristãos e judeus, o que até então não era comum.

Quando Hitler subiu ao poder em 1933 já contava com um poderoso contexto cultural de antipatia aos judeus. Muitos nomes ligados à história cultural da Alemanha foram usados para mostrar a suposta inferioridade dos judeus em relação aos alemães, por exemplo: além dos estudiosos alemães do naturalista

\footnotetext{
${ }^{124}$ NASCIMENTO, André dos Santos Falcão. o.c. p. 18.

${ }^{125}$ Ibid, p. 20.
} 
inglês Charles Darwin, que aplicaram suas teses ao evolucionismo social, podemos citar o filósofo Nietzsche, o compositor Richard Wagner (antissemita radical) e o próprio Martinho Lutero, todos foram usados pela propaganda nazista antissemita.

Uma das principais bandeiras do nazismo de Hitler era a pregação de superioridade da raça ariana. A isso soma-se o fato de que no contexto que Hitler chegou ao poder, a economia da Alemanha estava esfacelada e vários judeus detinham bons empregos e boas condições financeiras mesmo num país empobrecido. Com tudo isso, os nazistas começaram a acusar os judeus de serem culpados pela pobreza alemã e que eles deveriam ser expulsos de seus empregos e até do país, para que os alemães ficassem com o que seria deles.

Já em abril de 1933, Hitler proclamou um boicote nacional contra as lojas judias $^{126}$. Daí até o fím da guerra em 1945 a perseguição aos judeus só foi se acirrando cada vez mais.

Ainda em 1933 foi feito o chamado Sínodo Pardo em Berlim. Neste sínodo Ludwig Müller foi reconhecido bispo e os superintendentes gerais em exercício foram substituídos por pessoas consideradas leais ao nazismo. Também foi adotada a cláusula ariana, que impedia que qualquer pessoa que tivesse sangue judeu ocupasse algum púlpito na Alemanha ${ }^{127}$. Além da proibição de qualquer descendente de judeu subir ao púlpito, os que tivessem qualquer linhagem judaica seriam considerados inelegíveis ao ministério. Todos os pastores tinham de provar seu sangue puramente ariano. A Liga Pastoral de Emergência foi uma reação à cláusula ariana.

O nazismo se apropriou de várias ideologias para formular uma desjudaização do cristianismo. Foi apresentado um Jesus ariano, ou seja, um Jesus que fosse ascendente da raça considerada pelos nazistas como a superior e, a ideia de que Jesus fosse um judeu era completamente descartada. Além da reinterpretação dos textos bíblicos que faziam menção ao judaísmo, os hinários e catecismos das igrejas também foram reanalisados.

Para combinar com os ideais propostos por Hitler de superioridade racial, o Jesus que apresentava o Deus que se fez pobre, humilde e servidor foi substituído por uma imagem de Deus poderosa e gloriosa. A humanização de Deus foi

${ }^{126}$ CORNU, Daniel. o.c. p. 13.

${ }^{127}$ LUTZER, Erwin. o.c. p. 157. 
completamente desprezada e valorizada em seu lugar a divinização do ser humano, neste caso, do ariano. Hitler e o Estado nazista foram identificados como manifestações do próprio Deus e o povo alemão passou a ser visto como o povo escolhido de Deus.

É importante citar que o processo de desjudaização feito na Alemanha teve a ajuda e o consentimento da igreja cristã do país. Os chamados cristãos alemães entenderam que um país forte significaria uma igreja forte ${ }^{128}$. A explicação encontrada para as citações neotestamentárias de tendências judaicas seria o fato de que a mensagem do verdadeiro Jesus teria sido pervertida por grupos de judaizantes.

Em 1939 foi criado o Instituto para erradicar o judaísmo de dentro da igreja alemã. No catecismo foi feita uma lista de 12 mandamentos que incluíam manter o sangue puro e o casamento santo e honrar o füher e o mestre ${ }^{129}$.

Karl Barth foi um dos líderes e teólogos da época que mais lutaram contra as perseguições impostas contra os judeus. No pensamento de Karl Barth, que em 1919 em seu comentário à carta aos Romanos comentou o papel dos judeus expresso por Paulo nos capítulos 9 a 11, os judeus ocupavam um importante lugar para a fé cristã. Para Barth, Deus escolheu o povo judeu como Seu povo, para manifestar a Sua glória a toda a humanidade a fim de salvá-la. Deus se mostrou fiel para com o Seu povo mesmo nos momentos em que esse povo era infiel a Deus.

Barth procurou levar muito a sério a encarnação de Jesus. Em Jesus, Deus se fez carne, Deus encarnou como um homem, e como um homem judeu. Como já foi dito, a cristologia defendida por Barth era exatamente o contrário da pretendida pelo nazismo, pois o teólogo insistia na apresentação de Deus em Jesus Cristo, que revela um Deus servo e sofredor que salva a humanidade não pelo seu poder, mas pelo seu amor.

Os cristãos alemães afirmavam que os judeus foram rejeitados como povo de Deus por causa de sua infidelidade e pecados. Barth refutava esta ideia dizendo que se a infidelidade e pecado fossem fazer Deus rejeitar Israel como Seu povo, então Deus teria de ter rejeitado a igreja também. Para Barth a escolha de Israel,

\footnotetext{
${ }^{128}$ NASCIMENTO, André dos Santos Falcão. o.c. p. 76.

${ }^{129}$ Ibid, p. 86.
} 
assim como a da igreja, não está nos seus próprios méritos, mas sim na graça do próprio Deus ${ }^{130}$.

Barth afirmava que a presença dos judeus na terra era uma prova incontestável da existência de Deus. O teólogo via como demoníaco o que Hitler estava promovendo contra os judeus, enquanto eles existissem, seriam testemunhas do Deus vivo. Para Barth o que o nazismo estava fazendo era uma perseguição contra o próprio Deus. Cristo veio ao mundo como um judeu e se identificou com o seu povo, com a sua cultura, com os seus pecados. Barth destacou que era de caráter anticristão as perseguições contra os judeus e que quem atacava ao judaísmo, atacava na verdade as raízes da igreja. Barth afirmou que perseguir os judeus era rejeitar a graça de Deus ${ }^{131}$.

Poucos foram os teólogos que empreenderam tanto esforço, quer fosse político ou teológico, quanto Karl Barth. O teólogo via essa questão com olhos humanitários e teológicos, percebendo a manifestação do totalitarismo arbitrário do nazismo e a malignidade de um plano contra um povo que refletia o amor e o agir de Deus. Perseguição esta que acabaria chegando à igreja.

${ }^{130}$ HORDERN, William. o.c. p. 175 .

${ }^{131}$ CORNU, Daniel. o.c. p. 87. 


\section{4 \\ Última fase: Karl Barth entre 1945 - 1968}

Este é o último período da vida de Karl Barth. Não foi apenas uma longa vida (quase 83 anos), mas uma vida muito ativa, engajada e produtiva. Seguramente podemos afirmar que Barth deu a sua vida pela causa em que acreditava: o Evangelho de Jesus Cristo e as consequências que esta fé o levou a abraçar.

Barth foi um dos teólogos mais produtivos da história do cristianismo. Sua Dogmática Eclesiástica mesmo incompleta é maior que a Suma Teológica de Santo Tomás de Aquino (1225 - 1274). Roberto Schuler no prefácio que escreveu do livro de Barth Revelação de Deus como Sublimação da Religião, publicado no Brasil pela Fonte Editorial, disse que de tudo o que Barth escreveu ao longo de sua vida, existem mais de 50 mil páginas publicadas atualmente ${ }^{132}$. Ainda hoje, 45 anos após a sua morte, sua teologia continua sendo publicada e lida em todo o mundo. Muitas de suas obras são lidas como se fossem inéditas tamanho o volume de material escrito pelo teólogo.

Quando Barth faleceu, deixou uma garagem cheia, não de carros, mas de manuscritos. Eram sermões, artigos, livros, cartas, tratados, rascunhos, enfim, um verdadeiro tesouro teológico deixado por um dos mais produtivos e profundos teólogos de todos os tempos.

O último período de sua vida foi igualmente ativo. A Segunda Guerra Mundial e os horrores do nazismo finalmente acabaram em 1945. Felizmente Barth estava lá para ver isso de perto. Ele que tanto lutou e que não descansou um só momento enquanto não viu a Alemanha e a Europa livres daquele tremendo perigo. O engajamento político-social de Barth não terminou quando a guerra ou o nazismo terminaram. Mudou o contexto, mudaram as preocupações, mas o engajamento de Barth continuou até o fim.

Em 1946, Barth se esforçou para pedir às nações vencedoras da guerra que negociassem um acordo de paz que fosse razoável para com a Alemanha, a fim de que os erros cometidos em Versalhes não se repetissem. De um modo ou de outro, Barth contribuiu para a construção de uma Alemanha pós-guerra.

${ }^{132}$ SCHULER, Roberto, Prefácio in: BARTH, Karl. o.c. p. 10. 
No mesmo ano de 1946, Barth foi convidado a ser um professor visitante em Bonn, na Alemanha. Continuou com a escrita e publicação de sua Dogmática Eclesiástica, fez algumas viagens pela Alemanha com conferências teológicas e chegou aos Estados Unidos. Nesta última fase de sua vida, Barth recebeu mais 5 títulos de doutor honoris causa das Universidades de Budapeste na Hungria, de Edimburgo na Escócia, de Strasburgo na França, de Chicago nos Estados Unidos e da Universidade de Sorbone em Paris, França. Ao todo foram 11 títulos de doutor honoris causa.

Além dos títulos de doutor, Barth também recebeu a Condecoração Britânica do Mérito da Paz, em 1952 e o Prêmio Sonning em Copenhagen na Dinamarca, por contribuição à cultura europeia em 1963. Este título foi recebido por personalidades como Winston Churchil (1874 - 1965), Bertrand Russel (1872 - 1970) e Albert Schweitzer (1875 - 1965), por exemplo. Recebeu também a nomeação de senador honorífico da Universidade de Bonn em 1966, já com 80 anos de idade. No último ano de sua vida, foi nomeado como membro da Academia de Ciências Morais e Políticas na França e recebeu o prêmio Sigmund Freud da Academia de Letras de Darmstadt, na Alemanha.

Barth, neste último período, se voltou com dedicação à causa ecumênica e foi um dos principais participantes da assembleia de fundação do Conselho Mundial de Igrejas, que se reuniu em 1948 na cidade holandesa de Amsterdã. Além de ter sido convidado para ser um dos observadores no Concílio Vaticano II entre os anos de 1962-1965. Porém, Barth não pôde participar porque foi um momento de enfermidades, cirurgias e internações em sua vida.

Nas causas políticas, Barth acompanhou a criação do Estado de Israel em 1948 e viu o mundo sendo bipartido entre comunistas e capitalistas, entre soviéticos e norte-americanos. O teólogo não tomou partido de nenhum dos dois lados, mas permaneceu atento aos acontecimentos político-sociais da chamada Guerra Fria e sempre que entendeu ser necessário, posicionou-se.

Karl Barth faleceu aos 82 anos de idade, em 10 de dezembro de 1968, na sua cidade natal, Basiléia, na Suíça. Deixou a esposa Nelly Hoffmann, sua companheira por mais de 55 anos e quatro filhos (Franziska, Markus, Christoph e Hans Jakob).

Numa cerimônia realizada quatro dias depois de sua morte, a ecumenicidade que fez parte de sua vida estava representada: Lucas Burckhardt representou o 
Conselho de Igrejas da Basiléia; Max Geiger, a Faculdade de Teologia; Josef Hromádka representou as Igrejas da Europa Oriental; Hans Kung, a Igreja Católica; e Visser’t Hooft (1900 - 1985), o Conselho Mundial de Igrejas.

\section{1}

\section{O contexto histórico entre 1945 - 1968}

A morte de Hitler aconteceu em 30 de abril de 1945 e pouco tempo depois a Segunda Guerra Mundial finalmente chegara ao fim. Se na Primeira Guerra Mundial o papel dos Estados Unidos foi de protagonismo, neste novo conflito o país americano teve de compartilhar o protagonismo com a União Soviética. O grande revés sofrido pelo exército alemão foi em sua tentativa de dominar a capital soviética Moscou e na batalha de Stalingrado, a partir desses episódios, a força bélica alemã ficou bastante comprometida.

Com o fim da guerra, a Alemanha teve de render-se incondicionalmente. A Segunda Guerra tinha terminado, mas deixou um terrível legado: milhões de mortos, países destruídos e a ameaça de futuros ataques nucleares, pois as bombas atômicas jogadas contra o Japão pelos Estados Unidos davam uma impressionante demonstração de poder de uma das principais potências de um novo mundo que teria de conviver com a bipolarização.

Não era apenas a Alemanha e os países destruídos pela guerra que teriam de se reconstruir, o cristianismo europeu também teria muito trabalho para explicar ao mundo o que acabara de acontecer. Como falar de Deus para um mundo tão abalado com as desgraças das duas Grandes Guerras? Diante de um mundo atônito, como o cristianismo poderia se explicar depois ter sido tão negligente ante aos acontecimentos mundiais?

Os grandes teólogos cristãos, como Karl Barth, por exemplo, teriam muito trabalho para realizar no período posterior as duas guerras mundiais.

\subsection{1 \\ O mundo do Pós-Guerra}

Depois de 1945, o mundo se preparava para uma nova conjuntura internacional. A Europa estava se refazendo. Pela primeira vez na história da humanidade, o eixo hegemônico do mundo não estava na Europa. São os Estados 
Unidos que já despontavam para essa posição desde o fim da Primeira Guerra, não fosse o golpe causado pela Crise de 1929. Os Estados Unidos, do ponto de vista político e militar, não estariam sozinhos, teriam a incômoda companhia da União Soviética.

As primeiras décadas do pós-guerra foram marcadas por um fenômeno interessante: a Descolonização Afro-Asiática. A Descolonização marcou o fim do imperialismo clássico, que começou na Primeira Guerra, passou pela Crise de 1929 e foi consolidado após a Segunda Guerra. Marcou também a queda do mito da superioridade do homem branco ${ }^{133}$.

Após 1945, aconteceram uma série de movimentos que lutavam pela libertação política, econômica e cultural dos países da África e da Ásia. Como era uma crise do imperialismo, o país mais afetado foi o Reino Unido que admitiu a independência de várias ex-colônias. Antes mesmo da década de 50, alguns países asiáticos já alcançavam suas independências, como por exemplo: o Paquistão em 1947, mesmo ano da independência da Birmânia (atual Myanmar). Ainda em 1947 aconteceu a independência da Índia, depois das históricas manifestações pacifistas de Mahatma Gandhi (1869 - 1948). No mesmo ano, Israel foi declarado uma nação independente e suas terras seriam usadas para a criação de um Estado judeu e outro Estado palestino. Em 1948 foi declarado o Estado judeu de Israel. Todos esses países citados foram emancipados em relação ao Reino Unido.

Em 1948, é a vez do Ceilão e da Coréia e, em 1949, a Indonésia foi reconhecida como nação independente da Holanda. Até o fim da década de 50, praticamente todos os países asiáticos já eram independentes em relação as suas ex-metrópoles europeias.

No caso da África o processo foi um pouco mais lento e bem mais violento. As primeiras nações a se tornarem independentes no continente foram a Líbia, em 1951, Marrocos, Sudão e Togo, em 1956; Gana, em 1957; e Guiné em 1958. No continente negro foi a França a nação que mais perdeu colônias. Pelos consecutivos anos de exploração por parte das metrópoles, o continente africano teve sérios problemas com o subdesenvolvimento, o que ainda hoje não estão superados. 365.

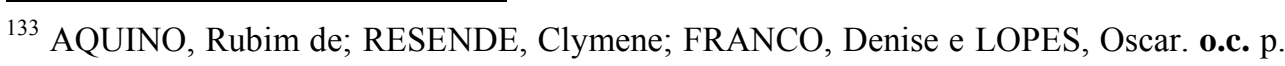


Embora tenha acontecido a independência dos países da Ásia e da África do ponto de vista político, do lado econômico não foi bem assim, pois essas nações continuaram dependentes das grandes nações capitalistas. Na América Latina, houve outro processo: mesmo antes da década de 40 já não existiam mais colônias políticas, à exceção das Guianas, por isso o processo de descolonização não foi necessário. No continente latino-americano, houve uma colonização de modo econômico e durante décadas, os países deste subcontinente dependeram diretamente do capital norte-americano, sendo uma região de forte influência e dominação dos Estados Unidos. Essa situação de exploração fez emergir na região a Teologia da Libertação, que se opunha ao domínio norte-americano.

Visivelmente os países de África, Ásia e América Latina estavam atrasados em relação aos países do Norte do planeta. Essas regiões receberam o nome de Terceiro Mundo, uma expressão muito usada para se referir a esses países que nem eram capitalistas desenvolvidos (Primeiro Mundo) e nem eram comunistas desenvolvidos (Segundo Mundo). A expressão Terceiro Mundo denotava o atraso socioeconômico destas nações.

\subsection{2 \\ A Guerra Fria}

A Guerra Fria é o contexto político que predominou após o fim da Segunda Guerra Mundial até a Queda do muro de Berlim em 1989. Durante aproximadamente 45 anos, o mundo viveu sob o constante perigo de uma guerra nuclear, especialmente nas décadas de 50 e 60 . O risco de começar uma Terceira Guerra Mundial era enorme e tido como certo por muitos. O nome Guerra Fria deveu-se ao fato de que as superpotências mundiais, Estados Unidos e União Soviética, nunca se enfrentaram diretamente em algum conflito, mas procuraram apoiar grupos rivais em conflitos ao redor do mundo.

Os Estados Unidos já dispunham da bomba atômica no fim da Segunda Guerra Mundial, tanto que as testou nas cidades japonesas de Hiroshima e Nagasaki. A União Soviética demorou um pouco mais, porém antes do término da década de 40, o país comunista já havia conseguido o artefato, e no início da década de 50 também conseguiu a bomba de hidrogênio, da qual os Estados Unidos também já dispunham. O medo e as ameaças das superpotências em 
iniciar uma guerra nuclear eram constantes. O medo aumentou ainda mais quando, no decorrer dos anos, outras nações conseguiram ter suas próprias bombas nucleares como o Reino Unido, França, Israel, África do Sul e Índia. A proliferação nuclear se tornaria um sério problema. Quando a bipolarização do mundo terminou em 1989, vários países (incluindo as ex-repúblicas soviéticas) detinham arsenal atômico ${ }^{134}$.

O que aconteceu com a Alemanha no fim da guerra era um reflexo de todo o planeta. Foram criadas duas Alemanhas, a Oriental, sob a influência comunista, e a Ocidental, sob a influência dos capitalistas, Berlim foi fatiada em quatro partes, onde três ficaram com os capitalistas: Estados Unidos, França e Inglaterra, e uma quarta parte com os comunistas da União Soviética. Para isolar a parte Ocidental de Berlim da parte Oriental, foi construído um muro no início da década de 60 pelos soviéticos. O Muro de Berlim mantinha duas ideologias e um mesmo país separados.

Do lado ocidental, os Estados Unidos lançaram uma série de pacotes que visavam fortalecer a sua posição no maior número de nações possíveis, foram eles: a Doutrina Truman (1947), que dava aos Estados Unidos a condição de fornecerem ajuda financeira e militar aos países ameaçados pelo comunismo para que estes não trocassem de lado. Os dois países imediatamente alcançados por essa doutrina foram Grécia e Turquia, pois estavam numa posição geográfica estratégica, próximos a chamada Cortina de Ferro, que correspondia ao Leste Europeu formado por países comunistas. Havia um medo de que gregos e turcos pudessem se tornar países comunistas fortalecendo ainda mais a posição dos soviéticos na região. A doutrina Truman foi aprofundada pelo chamado Plano Marshall, que pôs na prática a iniciativa americana de ajuda financeira aos países mais vulneráveis.

Também foi criada a OTAN (Organização do Tratado do Atlântico Norte), uma aliança militar com o objetivo de proteção dos países membros contra qualquer investida bélica soviética.

Já do lado oriental, a União Soviética não ficou para trás e tratou de defender sua posição no cenário político internacional. Também aqui foi lançado um pacote com medidas de fortalecimento político, econômico e militar aos países

\footnotetext{
${ }^{134}$ HOBSBAWM, Eric. Era dos Extremos 1914-1991. p.233.
} 
do bloco socialista. Desde 1919, o então presidente soviético Vladimir Lênin (1870 - 1924) havia criado o Komintern, que seria uma espécie de Liga Internacional de Partidos Comunistas. Esse intento vigorou até 1943, e visava fortalecer a posição dos Partidos Comunistas em diferentes países na luta contra o capitalismo.

Já na Guerra Fria foi criado em 1949 o Comecon, que era o equivalente ao Plano Marshall. Visava fornecer ajuda financeira aos países socialistas, especialmente os do Leste Europeu. Por fim, foi criado o Pacto de Varsóvia, uma organização militar que visava à autoproteção dos países socialistas daquela região.

Vários foram os conflitos travados indiretamente por capitalistas e socialistas ao longo da Guerra Fria. Os exemplos mais marcantes que podemos citar seriam: a Guerra da Coréia (1950 - 1953), que dividiu a península coreana em Norte, apoiada pela União Soviética e China, de um lado; e o Sul, apoiado por Estados Unidos e Reino Unido por outro lado. O historiador Eric Hobsbawn comenta que neste conflito o resultado teria sido um empate, já que nenhum sistema prevaleceu sobre o outro, e o país foi dividido ao meio ${ }^{135}$.

Houve também a Guerra do Vietnam (1955 - 1975), que outra vez colocou americanos e soviéticos em lados opostos. O primeiro apoiando o Vietnam do Sul e o segundo apoiando os vietnamitas do Norte. Foi um conflito longo e terrível que matou milhares de pessoas nos países envolvidos. As consequências deste conflito foram desastrosas para os Estados Unidos.

Certamente o episódio de maior iminência de uma guerra nuclear aconteceu em 1962, na Crise dos Mísseis. Este conflito começou quando a União Soviética instalou bases de mísseis na Baía dos Porcos em Cuba, em resposta a instalação de bases americanas na Turquia. Naquela oportunidade, os Estados Unidos eram presididos por John Kennedy (1917 - 1963) e a União Soviética por Nikita Kruschev (1894 - 1971). Os mísseis em Cuba estavam diretamente apontados para a Flórida e por muito pouco a temida guerra nuclear não aconteceu.

Os países da América Latina, Ásia e África foram denominados de Terceiro Mundo, um mundo marcado pelo subdesenvolvimento. Nessas regiões do globo foi feito o que alguns chamaram de Neocolonialismo, uma nova forma de

\footnotetext{
${ }^{135}$ Ibid, p. 234.
} 
colonizar, desta vez não mais através do domínio político, mas de forma econômica, onde os países tinham governos autônomos e dependiam do capital das potências.

Obviamente o cristianismo não ficou imune a toda a tensão existente no período da Guerra Fria, sobretudo até o fim da década de 60. Quase sempre o cristianismo tendeu para o lado dos capitalistas e dos Estados Unidos, por dois motivos básicos: primeiro por causa da influência norte-americana no Ocidente onde estava a maior força do cristianismo, tanto católico quanto protestante. Segundo, por causa dos ideais ateístas que a filosofia comunista abraçava e queria levar em todos os países aonde chegava. Os cristãos tinham medo do ateísmo comunista e o viram como seu principal inimigo.

Pio XI em 1937 publicou duas encíclicas. Numa condenava o nazismo e na outra condenava o comunismo ${ }^{136}$. Mesmo antes da Guerra Fria o comunismo já assustava o pontífice e a Igreja Católica.

O Papa Pio XII foi um ferrenho opositor do comunismo, como muitos historiadores pensam, preferiu inclusive o nazismo ao comunismo ateísta na década de $30^{137}$. Enquanto Pio XII foi papa ele lutou contra o comunismo considerando o pior dos males existentes naquele contexto mundial.

O Cardeal Pacelli (Pio XII), que em 1936 tinha feito uma duradoura visita aos Estados Unidos e se encontrado com o recém-eleito presidente Roosevelt (1882 - 1945), foi um inimigo voraz do comunismo. A energia que lhe faltou para combater o nazismo sobrou diante da ameaça vermelha, e depois da Segunda Guerra Mundial sua política internacional se limitou à oposição ao comunismo. Durante o seu pontificado qualquer católico que apoiasse os comunistas, corria o risco de ser excomungado ${ }^{138}$.

A tensão durante a Guerra Fria era tão grande que no conclave que elegeu o sucessor de Pio XII em 1958, os cardeais da Hungria e da Iugoslávia (nações socialistas) não puderam participar por não terem liberação dos governos de seus respectivos países ${ }^{139}$.

\footnotetext{
${ }^{136}$ GONZALEZ, Justo L. Uma História Ilustrada do Cristianismo - A Era Inconclusa. São Paulo: Editora Vida Nova, 1998. p.43.

${ }^{137}$ MCBRIEN, Richard P. Os Papas - Os pontífices de São Pedro a João Paulo II. 3ed. São Paulo: Editora Loyola, 2013. p. 370.

${ }^{138}$ GONZALEZ, Justo L. Uma História Ilustrada do Cristianismo - A Era Inconclusa. p. 45 .

${ }^{139}$ MCBRIEN, Richard P. o.c. p. 375.
} 
O Papa João XXIII, em 1963, recebeu no Vaticano a filha e o genro de Kruschev, o então primeiro-ministro da União Soviética. Num contexto de tanta hostilidade, o Papa João XXIII, que tinha muita habilidade em assuntos diplomáticos, conseguiu uma verdadeira façanha: garantiu junto ao governo de Moscou a participação de bispos católicos dos países da Cortina de Ferro no Concílio Vaticano II. Com este gesto, João XXIII quebrou uma sequência de décadas sem relações diplomáticas entre o Vaticano e a União Soviética e ainda gerou um processo de diálogo entre o Ocidente e o Oriente ${ }^{140}$.

O sucessor de João XXIII foi Paulo VI (1963 - 1978), este procurou ter uma política internacional mais aberta: viajou por diversos países, como na viagem a Israel em 1964 onde se reuniu com o Patriarca Atenágoras (1886 - 1972), da Igreja Ortodoxa. Paulo VI discursou na ONU em 1965, porém o papa continuou com uma postura anticomunista.

Durante a Guerra Fria, especialmente no pontificado de Pio XII, o papel dos partidos políticos ligados à Igreja Católica em países ocidentais foi de grande relevância. Os partidos democrata-cristãos eram nitidamente anticomunistas e apresentavam uma folha de serviços antifascistas e um programa social não socialista $^{141}$.

No Brasil o golpe militar de 1964 foi antecedido pela Marcha das Famílias com Deus pela Liberdade. O evento foi liderado por setores conservadores da sociedade brasileira, como a igreja (tanto católica quanto protestante), por exemplo. O golpe de 1964 foi apoiado pelos Estados Unidos e durante a década de 60 e metade da década de 70 organizou uma verdadeira caça aos comunistas no país.

No lado protestante também houve intensas reações diante da bipolarização do mundo. Na Alemanha Oriental (portanto comunista) a população era de maioria protestante, e teve de enfrentar uma série de restrições civis impostas pelo governo. Em outros lugares a relação entre Igreja e Estado comunista foi mais amena, e a fé foi praticamente ignorada pelos governos políticos como sendo algo do passado, por exemplo, na Hungria e na Tchecoslováquia. No país tcheco houve a participação do pastor Hromádka, a quem Barth dirigiu uma carta durante a

\footnotetext{
${ }^{140}$ ALBERIGO, Giuseppe. Breve História do Concílio Vaticano II. Aparecida: Editora Santuário, 2006. p. 42.

${ }^{141}$ HOBSBAMW, Eric. Era dos Extremos 1914-1991. p. 236.
} 
Segunda Guerra. Este pastor viu com bons olhos o regime comunista em seu país e, na forma igualitária como o mesmo tratava as igrejas. Hromádka enquanto viveu nos Estados Unidos durante o nazismo, percebeu que muito do que se considerava cristianismo naquele país, não passava de justificação da democracia liberal e do capitalismo. Para Hromádka, o medo que o cristianismo convencional nutria pelo comunismo era injustificado. Segundo ele, o Deus apresentado pelos marxistas era apenas uma ficção e não o verdadeiro Deus revelado na Bíblia ${ }^{142}$.

Já na teologia norte-americana protestante e fundamentalista, que até hoje é a principal fonte de teologia nos círculos pentecostais no Brasil, elaborou-se uma escatologia onde textos do apocalipse passaram a ser interpretados apontando sempre para a União Soviética como o berço do anticristo. Esta foi a escatologia disseminada pelo mundo (inclusive no Brasil) através dos ideais do Destino Manifesto, a ideia de que os Estados Unidos eram a maior nação cristã do mundo que deveria proteger a América Latina e levar o Evangelho a todas as nações da Terra.

A teologia fundamentalista norte-americana do período da Guerra Fria via a União Soviética e os comunistas como o principal inimigo à fé cristã no mundo, produzindo uma verdadeira repulsa aos movimentos socialistas e uma devoção quase idolátrica aos Estados Unidos, devoção que ainda não foi totalmente superada hoje. A teologia fundamentalista norte-americana gerou uma preocupação missionária de levar o cristianismo americanizado a todo o planeta. Esse discurso missionário quase sempre foi confundido com os ideais imperialistas dos Estados Unidos. Os norte-americanos eram uma nação que se orgulhava de ser cristã, como o fariseu da parábola que se orgulhava por não ser um pecador ${ }^{143}$. Por isso, muitas culturas foram violentadas por causa de um cristianismo norte-americano que queria implantar junto com as igrejas o american way of life $e^{144}$.

Nos Estados Unidos a propaganda anticomunista foi usada de modo intenso. Graças a esse discurso, presidentes foram eleitos no país com a plataforma de intolerância ao perigo comunista mundial, e conflitos militares ao redor do mundo foram justificados pelo mesmo motivo.

\footnotetext{
${ }^{142}$ GONZALEZ, Justo L. Uma História Ilustrada do Cristianismo - A Era Inconclusa. p.77.

${ }^{143}$ Cf. Lc 18;9-14.

${ }^{144}$ American way of life significa O Modo Americano de vida.
} 
O fato é que, durante os primeiros 25 anos de Guerra Fria, onde estivesse a Igreja ela seria tentada a pensar de acordo com a ideologia política adotada pelo país. Por exemplo: se um país fosse aliado dos capitalistas, os cristãos daquela região veriam o comunismo como um inimigo à fé que deveria ser combatido. Se um país fosse aliado dos comunistas e sua política religiosa fosse ao menos tolerante, estes veriam os Estados Unidos como a nação que queria dominar o resto do mundo, e às vezes usava a própria fé cristã para isso.

Não fossem os esforços da Teologia da Libertação (no lado católico) e posteriormente a Teologia da Missão Integral (no lado protestante), o cristianismo latino-americano teria sido subserviente à teologia norte-americana. Os teólogos ligados à Teologia da Libertação e à Teologia da Missão Integral propuseram um referencial teórico de enxergar a realidade socioeconômica partindo do marxismo, e lutaram para gerar uma teologia e uma eclesiologia encarnadas com a realidade latino-americana, livres da influência dominadora dos Estados Unidos, mas também não submissa à União Soviética.

\subsection{3 \\ Novas tendências teológicas na Guerra Fria}

O século XX foi muito intenso. Até por conta dos grandes acontecimentos mundiais, como as duas guerras mundiais na primeira metade do século, a bipolarização do mundo e a constante ameaça de guerra nuclear que caracterizou toda a segunda metade do século.

Diante de demandas tão graves a teologia precisou dar ao ser humano respostas que fossem condizentes e satisfatórias aos muitos dramas pelos quais a humanidade passou neste período. O sentimento de grande euforia que tomou conta do mundo, especialmente entre o fim do século XIX e o início do século XX, foi abraçado pela Teologia Liberal que, como vimos, se entregou ao avanço progressista que contagiou o mundo.

Lamentavelmente, o clima de grande euforia com a capacidade intelectual humana que levaria o planeta a índices sem precedentes de desenvolvimento, acabou eclodindo na Primeira Guerra Mundial de 1914, quando o tão sonhado progresso foi usado para matar! A busca exasperada pelo progresso fez com que potências entrassem em choque umas com as outras, e a tecnologia fosse usada 
para construir materiais de destruição em massa. Entre 1918 e 1933 a situação não foi bem resolvida e, ainda na década de 30, o mundo entrava numa nova guerra mundial, ou uma continuação da guerra anterior. Só que dessa vez em maiores proporções e com potencial destrutivo ainda maior. Resultado: milhões de mortos e países devastados.

Depois do fim da Segunda Guerra Mundial, o progresso voltou a mostrar seu lado destrutivo. As potências tinham desenvolvido a bomba atômica. Era o que havia de mais tecnológico na indústria bélica e o maior poder de destruição que a humanidade já tinha conhecido. O legado do progressismo era algo terrível. A qualquer hora poderia explodir uma guerra nuclear com o risco de acabar com a raça humana e o planeta Terra.

Com os riscos nucleares, as potências do antigo sistema mundial perceberam que era a hora de frearem os seus impulsos, caso contrário, poderiam não ter uma nova oportunidade. A Descolonização Afro-asiática fez parte desse processo. Ainda que a independência dos países em questão não tenha sido completa, pelo menos evitou uma série de conflitos políticos.

A Primeira Guerra Mundial fez com que surgissem reações contra a Teologia Liberal. A chamada Teologia da Crise ou Teologia Neo-Ortodoxa foi uma enérgica reação ao liberalismo teológico e uma relevante resposta ao mundo abalado com as consequências da Primeira Guerra. Em 1945 o mundo estava atordoado com a carnificina provocada pela Segunda Guerra. A Europa, que sempre creu em Deus, estava perplexa e logo surgiu o questionamento: Será que Deus está nos castigando? Diante dessa indagação muitos afirmaram enfaticamente que sim! Outros, diante dos horrores da guerra, começaram a levar a sério a frase do filósofo Nietzsche que Deus estava morto! Deus havia saído de cena, e o que aconteceu com seu antigo povo em Auschwitz era uma prova incontestável disso. A Segunda Guerra Mundial, Auschwitz e o medo nuclear colocaram a teologia e a antiga representação de Deus em xeque.

A teologia precisou se repensar. Diante dessa nova demanda, o mundo teológico começou a abrir os seus olhos para uma teologia que era produzida fora da Europa. Ficou conhecido o importante testemunho de pessoas de fé num período de descrença quase que mundial. Nesse período uma teologia engajada e testemunhada foi muito necessária. A teologia precisou fazer muito mais do que falar. 
Durante a Segunda Guerra Mundial, o teólogo Rudolf Bultmann (1884 1976) publicou o ensaio teológico Novo Testamento e Mitologia em $1941^{145}$. O impacto causado por Bultmann foi grande. Na década seguinte, a questão da demitologização foi amplamente debatida nos círculos teológicos europeus. Posteriormente, Bultmann publicou outro ensaio chamado Jesus Cristo e Mitologia. Naquele período o teólogo procurou apresentar uma imagem de Jesus livre dos mitos nos quais Jesus era apresentado, segundo ele, na linguagem dos Evangelhos. O teólogo enaltecia o Cristo da fé num momento em que havia séria discussão sobre o Jesus histórico.

Talvez o teólogo mais relevante para a teologia da segunda metade do século XX foi Jurgen Moltmann. Não seria exagero dizer que sua Teologia da Esperança (1964) tenha representado para a geração pós-guerra o que a Carta aos Romanos (1919) de Karl Barth representou depois do Liberalismo na primeira metade do século XX.

Quando Moltmann tinha 17 anos foi convocado para o exército alemão. Perto do fim da guerra ele foi prisioneiro na Bélgica e na Inglaterra durante mais de três anos e conheceu de perto os horrores dos conflitos. Foi neste período que Moltmann teve uma profunda experiência de Deus. Ainda em 1948, deu início aos seus estudos teológicos que concluiu em $1952^{146}$. Em seguida, Moltmann foi ordenado pastor luterano.

A experiência durante a guerra fez Moltmann refletir sobre a essência da vocação cristã. A Esperança passou a ser um ponto central em sua vida e obra. Na Teologia da Esperança a escatologia é trazida para o centro do pensamento teológico. Moltmann ensinou aos europeus o valor da esperança futura respaldada não na glória, mas sim na cruz de Cristo.

Em sua obra o Deus crucificado de 1972, Moltmann levou a sério a tarefa de repensar a imagem de Deus mediante a cruz de Cristo. O Deus crucificado era uma resposta de Moltmann ao horror que o mundo viveu durante a guerra e ao drama de Auschwitz. Para o teólogo, depois da guerra, não havia mais nada em que crer senão em Deus. Moltmann propôs a imagem de Deus que é revelada em Jesus Cristo, não de um Deus Todo-poderoso, como Barth já havia alertado, mas

\footnotetext{
${ }^{145}$ GIBELLINI, Rosino. o.c. p. 33.

${ }^{146}$ MONDIN, Battista. o.c. p. 283.
} 
como um Deus humilde e sofredor, que demonstra o seu poder exatamente no fato de se fazer fraco para se relacionar com sua criação.

O Deus que Moltmann apresenta em sua obra é o Deus cristão que sofre por amor. Não é um sofrimento que vem de fora, que lhe é imposto, mas um ato livre de amor. Seu trabalho foi de grande relevância, colocando-o entre os teólogos de maior destaque do século XX.

Além das tentativas de respostas vindas da Europa, o mundo conheceu a fé engajada de pessoas de várias partes do mundo. Da América do Norte veio a luta do pastor batista Martin Luther King Jr (1929 - 1968), que literalmente deu a sua vida na luta contra o racismo que assolava os Estados Unidos. O pastor Martin Luther King Jr fez históricos discursos, como o lendário I have a dream $^{147}$, proferido na marcha de Washington por empregos e liberdade em 1963. King teve posturas ecumênicas na luta contra a desigualdade. Foi assassinado em 1968 quando liderava a passeata dos pobres ${ }^{148}$.

Na América Latina surgiu a Teologia da Libertação, que lutou arduamente contra os sistemas de opressão e de ditaduras que se espalhavam pelo subcontinente. Vários expoentes da Teologia da Libertação foram perseguidos, presos, torturados e até mortos pelas ditaduras militares latino-americanas, como por exemplo, o arcebispo de San Salvador Dom Oscar Romero (1917 - 1980), que foi executado por um atirador de elite do exército de El Salvador enquanto realizava uma missa.

Da Ásia, o exemplo da incansável madre Teresa de Calcutá (1910 - 1997), que como missionária católica na Índia lutou bravamente contra a fome e a miséria tão presentes no país e serviu de exemplo para todo o mundo de uma cristã engajada e ativa nas causas sociais. Também poderíamos citar o exemplo do arcebispo anglicano Desmond Tutu (1931 - ). Líder da Igreja Anglicana na África do Sul e amigo do metodista e líder sul-africano, Nelson Mandela (1918 - 2013). Tutu foi o primeiro negro a ser nomeado arcebispo anglicano na África do Sul e lutou contra o apartheid, regime de segregação racial no país. Os exemplos

\footnotetext{
${ }^{147}$ I have a dream significa Eu tenho um sonho.

${ }^{148}$ GONZALEZ, Justo L. Uma História Ilustrada do Cristianismo - A Era Inconclusa. p. 97.
} 
citados acima (Martin Luther King Jr, Madre Teresa de Calcutá, Desmond Tutu e Nelson Mandela) foram condecorados com o prêmio Nobel da paz ${ }^{149}$.

A teologia cristã precisou se adaptar aos novos tempos. Precisou repensar na representação tradicional da imagem de Deus e precisou deixar de ser eurocêntrica e olhar com atenção para a América Latina, Ásia e África, onde o testemunho cristão e a luta em nome da fé falaram mais alto que os tratados teológicos. Percebe-se nos exemplos dados por Luther King, Madre Teresa, Mandela e Tutu a fé comprometida com os pobres e na luta pelos direitos humanos. Pessoas de vidas absolutamente abnegadas e dedicadas ao Evangelho proposto por Jesus. O mundo contemporâneo, depois de tudo que viveu, reverencia estes exemplos, é o Evangelho que precisa ser pregado no contexto de hoje.

\section{2 \\ Karl Barth entre 1945 - 1968}

Karl Barth teve uma vida muito ativa, sempre se inteirou dos acontecimentos sócio-políticos-teológicos que aconteciam no mundo e pôde viver um período de grandes acontecimentos históricos.

A última etapa de sua vida continuou sendo marcada por uma produção intensa. Deu continuidade a elaboração de sua Dogmática, manteve-se atento aos acontecimentos político-sociais do período marcado pela Guerra Fria. Com as consequências geradas pelo fim da Segunda Guerra Mundial, procurou como teólogo, dar ao mundo respostas para questões essenciais. Procurou responder de modo relevante às crises que haviam sido geradas pela carnificina provocada pela guerra.

Barth entendeu a importância de um cristianismo ecumênico para aquele momento da história da humanidade e, com isso, participou ativamente do Conselho Mundial de Igrejas, na conferência de Amsterdã em 1948. Barth se aproximou de modo considerável da teologia católica, tanto que em 1962 foi convidado para participar como um dos observadores protestantes no Concílio Vaticano II. Infelizmente, Barth não pôde participar do Concílio por questões de saúde, mas em 1966 fez uma proveitosa visita ao Vaticano e foi recebido pelo próprio Paulo VI.

\footnotetext{
${ }^{149}$ Martin Luther King Jr em 1964, Madre Teresa em 1979, Desmond Tutu em 1984 e Nelson Mandela em 1993.
} 
Assim como Barth foi ativo no período entre-guerras, na ascensão do nazismo, na Segunda Guerra Mundial, na Guerra Fria não foi diferente. Ele continuou atento e atuante nas grandes questões políticas mundiais.

\subsection{1}

\section{O engajamento de Karl Barth num mundo bipolarizado.}

O novo contexto político que se seguiu a Segunda Guerra Mundial exigiu novamente o engajamento e posicionamento de Karl Barth. O cenário era de incertezas e ameaças. Incertezas porque ninguém sabia o que esperar de capitalistas e comunistas, e um contexto no qual o mundo se encontrava sob a influência de duas grandes potências era algo inédito. Especialmente no lado ocidental influenciado pelos Estados Unidos, muitos se precipitaram em tomar posição anticomunista. E, além de dúvidas, o mundo da época sofria a séria e iminente ameaça de uma Terceira Guerra Mundial, que desta vez superaria o poder de destruição das guerras anteriores por se tratar de um possível conflito nuclear.

Depois da reação provocada por Barth diante do fracasso do ideal de progresso com a Primeira Guerra, seu posicionamento intenso durante o nazismo na Alemanha e seu engajamento durante a Segunda Guerra, muitos esperavam dele alguma posição diante do novo contexto político mundial. E ele não se calou.

No ano de 1949, Barth escreveu alguns artigos de alto teor político-social. Uma reflexão muito relevante proposta por ele foi sobre a pobreza, neste artigo ficou clara a sua preocupação com os menos favorecidos e muitos postulados que mais tarde estiveram presentes na Teologia da Libertação e na Teologia da Missão Integral já estavam no artigo proposto por Barth.

Barth tratou da questão da pobreza de modo teológico e social. Para ele, ao longo da Bíblia, Deus não assumiu postura neutra diante do choque entre ricos e pobres. Deus sempre tomou as dores do pobre e do necessitado e exigiu do rico opressor que fosse feita justiça. Como os ricos podem tomar conta de seu próprio futuro, Deus se coloca ao lado dos pobres ${ }^{150}$.

Com alguns argumentos bíblicos, Barth procurou mostrar a predileção que Deus faz pelo pobre em toda a Escritura. Barth apontou para o fato de que não

\footnotetext{
${ }^{150}$ BARTH, Karl. A Pobreza in: ALTMANN, Walter (Org.). o.c. p.352.
} 
existe nenhuma passagem bíblica em que os direitos dos ricos são enumerados, ao passo que existem várias passagens onde não apenas são relacionados os direitos dos pobres, como Deus se coloca como o juiz que vai julgar os ricos, caso a justiça não seja feita.

Outro argumento usado por Barth é que não existe passagem bíblica em que a riqueza é exaltada ou louvada. De outro lado o sermão das bem-aventuranças é claro em dizer que felizes são os pobres... ${ }^{151}$. Não há bem aventurança na riqueza. Pelo contrário, há a chance do rico estar próximo do sistema que oprime o pobre e consequentemente se perder.

Barth afirmou que a Bíblia está do lado do pobre, e o Deus que a Bíblia revela está do lado dos pobres e chama os seus discípulos a fazerem o mesmo. A pobreza era uma condição que expressava o domínio do mal nesta vida e é uma das claras consequências do pecado humano. Por isso, no Reino de Deus, Jesus porá fim à pobreza e à injustiça.

Para Barth, foi na pobreza que Deus demonstrou a verdadeira riqueza, foi na humilhação que Deus mostrou o verdadeiro poder. O Filho de Deus, eternamente rico e fonte de toda a vida, veio à Terra em pobreza para ter um encontro verdadeiro com o ser humano. A pobreza fez parte de toda a vida terrena de Jesus, desde seu nascimento que aconteceu num estábulo em Belém, até a sua morte, pregado nu à cruz $^{152}$. O ser humano, a fim de tornar-se rico em Jesus, deverá seguir o seu exemplo de humilhação e confessar sua pobreza. Com este posicionamento, Barth não apenas deixou claro o seu engajamento social, como começou a apresentar a Europa uma resposta teológica relevante diante da decepção que tomara conta do continente depois da guerra: a resposta do Deus humilde, revelado em Jesus Cristo. Barth já apresentava a ideia de um Deus humilde bem antes do lançamento de o Deus crucificado de Moltmann.

No mesmo ano de 1949, Barth publicou um artigo intitulado A Igreja no confronto Leste - Oeste. Este artigo foi proveniente de uma conferência apresentada na Catedral de Berna no dia 6 de fevereiro. A maior parte da igreja ocidental desde cedo assumiu posição pró Estado Unidos e elegeu o comunismo soviético como seu principal inimigo. Nesta conferência, Barth não se precipitou em defender o lado ocidental. Pelo contrário, se colocou numa posição de

${ }^{151}$ Cf. Mt 5;3.

152 BARTH, Karl. O Cristão na Sociedade in: ALTMANN, Walter (Org.). o.c. p. 353. 
neutralidade, porém não uma neutralidade de omissão, mas uma posição que lhe daria a liberdade para defender e atacar quaisquer dos dois lados de acordo com a necessidade.

Barth não apoiou o regime capitalista ocidental e também não apoiou o regime comunista oriental. A aparente demora em se posicionar rendeu a Barth muitas críticas de líderes ocidentais que exigiam dele uma postura pró-ocidente. Muitos queriam que ele assumisse uma postura com a mesma voracidade que assumiu na época do nazismo, mas Barth se negou a ver os dois momentos como semelhantes.

Para Karl Barth o nazismo e o comunismo não eram a mesma coisa. Na década de 30 muitos líderes cristãos (católicos e protestantes) se apressaram em apoiar o nazismo de Hitler porque viam nele uma ameaça menor que o comunismo ateísta da União Soviética, e os resultados mostraram que a opção foi desastrosa. No entendimento de Barth o papel da igreja é o de anunciar o Reino de Deus, e o conflito entre Leste e Oeste não era um conflito entre o bem e o mal, mas apenas um conflito por poder, um conflito ideológico de duas concepções antagônicas de mundo ${ }^{153}$.

$\mathrm{Na}$ época do nazismo foi necessário um posicionamento ferrenho, pois o Estado não era apenas totalitário do ponto de vista político. O nazismo reivindicava para si um status divinizador: queria que seu líder fosse visto como um Messias, queria alinhar a Revelação de Deus com a doutrina nazista. Para Barth essas coisas eram inaceitáveis e isso não se repetia no comunismo, que não fazia uso de um falso profetismo e nem procurava cobrir-se de uma máscara cristã $^{154}$. O comunismo se declarava ateu e não tinha pretensão de dominar a mensagem cristã como no caso do nazismo. Como citado, o pastor tcheco Hromádka, amigo de Barth, via na distância que o comunismo queria manter da religião como algo que acabou sendo favorável ao protestantismo, pois lhe deu os mesmos direitos que o catolicismo tinha.

Barth concordou que o regime comunista não era democrático, mas não via a necessidade de combatê-lo de acordo com alguns valores do direito natural que eram definidos apenas pela civilização ocidental ${ }^{155}$. Por não atacar o totalitarismo

\footnotetext{
${ }^{153}$ FILHO, Manoel Bernardino de Santana. o.c. p. 100.

${ }^{154}$ CORNU, Daniel. o.c. p. 164.

${ }^{155}$ Ibid, p. 155.
} 
comunista, Barth recebeu algumas críticas, que foram rejeitadas por ele, porque vinham de pessoas que claramente apoiavam o fascista Franco em sua ditadura espanhola apenas porque este estava alinhado com os Estados Unidos ${ }^{156}$.

Durante as décadas mais tensas da Guerra Fria, Barth demonstrou ser um teólogo de vanguarda ao afirmar que toda mudança política dava à comunidade de fé uma oportunidade de ser renovada pela Palavra de Deus ${ }^{157}$. Para o teólogo, a igreja deveria se concentrar em proclamar o Evangelho, que deixa claro que Deus é a favor do ser humano e, portanto contrário à sua destruição oriunda de onde quer que seja. Para Barth a igreja não poderia assumir a responsabilidade de nenhum ismo, e também não poderia recusar nenhum ${ }^{158}$.

O também teólogo suíço Emil Brunner (1889 - 1966) escreveu uma carta aberta criticando a postura de Barth e exigindo que ele se fizesse entender em seus posicionamentos. Brunner acreditava que Barth deveria se posicionar contrário aos comunistas, mas Barth respondeu sua carta à altura deixando clara a sua posição. Para ele não bastava se posicionar como na época do nazismo, porque a história não se repetia a ponto de apenas ter de aplicar no presente a mesma receita do passado. Cada contexto exigia uma nova reflexão.

Quando viajou à Hungria comunista em 1947 a convite de cristãos daquele país, Barth pôde ampliar sua reflexão. Quando retornou à Suíça, falou sobre o que encontrou na Hungria. Seu posicionamento mais uma vez foi marcado pelo equilíbrio. Barth afirmou a dificuldade que viu em viver num país que fazia parte da chamada cortina de ferro, mas por outro lado, disse que na Hungria encontrou pessoas mais calmas e serenas que na Basiléia.

Barth foi criticado por pessoas ligadas ao governo da Suíça, que afirmavam que seus posicionamentos serviam para alimentar o partido comunista suíço. No seu artigo A Igreja no confronto Leste - Oeste, Barth afirmou que a igreja não deveria enfrentar a questão como políticos, mas como cristãos, pois se encarasse como políticos, naturalmente a igreja ocidental ficaria do lado dos Estados Unidos e demonizaria a União Soviética, sem levar em consideração que ambos eram apenas posicionamentos ideológicos conflitantes. A igreja deveria enxergar a situação sem a influência política tendenciosa, e não ignorar que o capitalismo

${ }^{156} \mathrm{Ibid}$, p. 163.

${ }^{157}$ Ibid, p. 147.

${ }^{158}$ Idem. 
ocidental também fazia as suas vítimas e também tinha posições anticristãs. Barth insistia que analisasse a situação como cristãos: preocupados com o sofrimento humano causado por quem quer que fosse. A causa de Deus não era a causa do Oeste e nem tampouco a do Leste. A causa de Deus era o ser humano. Barth disse que a igreja ficaria impossibilitada de dizer um não definitivo para o Leste, enquanto houvesse no Oeste uma liberdade para provocar crises econômicas e despejar comida no mar, quando em muitos lugares do planeta pessoas passavam fome ${ }^{159}$.

Barth disse aos cristãos que eles não podiam colaborar com o conflito e que os cristãos nada tinham a ver com o confronto. Sua posição não era uma posição dualista, já que para ele era um mero conflito por poder. A igreja deveria estar atenta aos acontecimentos mundiais para se posicionar contrária a qualquer possibilidade de uma nova guerra mundial. $\mathrm{O}$ grito enérgico que a igreja deveria dar naquela conjuntura era o grito de paz! Diante da política a igreja deveria lutar sempre por sua posição de liberdade cristã. Para o teólogo, a definição de liberdade não estava clara nem de um lado nem de outro. O lado oriental era marcado pela falta de liberdade democrática; mas o lado ocidental, pela falta de liberdade imposta pelo consumo capitalista.

A posição equilibrada de Barth foi fruto de seu pensamento teológico. Ninguém poderia acusá-lo de omissão, pois sua história já provara que ele sempre foi um líder e um pensador engajado. Quem expôs a carreira e a própria vida durante a vigência do nazismo não teria motivo algum para temer a Guerra Fria. Particularmente, seu temor estava na possibilidade de uma nova guerra. Para Barth, a igreja deveria construir e isso só seria possível se ouvisse ambos os lados envolvidos no conflito, como ele fez. Ao mesmo tempo ele afirmou que os cristãos deveriam sempre testemunhar aberta e seriamente aos outros a própria fé $^{160}$.

Barth foi acusado de não se posicionar quando o exército comunista invadiu a Hungria em 1956. Barth permaneceu com sua convicção, e isso não o impediu de fazer algo prático diante daquele cenário. Em 11 de março de 1957, Barth foi um dos teólogos que assinou um telegrama da Aliança Reformada Mundial,

\footnotetext{
${ }^{159}$ BARTH, Karl. A Igreja no Confronto Leste-Oeste in: ALTMANN, Walter (Org.). o.c. p. 345.

${ }^{60}$ BARTH, Karl. Decisão Política na Unidade da Fé in: ALTMANN, Walter (Org.). o.c. p. 384
} 
endereçada ao ministro Janos Horvath (1921 - ) sobre a prisão de pastores reformados na Hungria. Em virtude daquele telegrama ao menos dois pastores foram libertados num intervalo de 24 horas $^{161}$.

Em 1958, Karl Barth recebeu uma carta do pastor Johanes Hamel da República Democrática da Alemanha (Alemanha Oriental). Na carta o pastor pedia a Barth respostas sobre sua situação como cristão na Alemanha comunista. O pastor queria saber como era possível se engajar num mundo autodenominado não-cristão. Ele não queria simplesmente sair do país. Pelo contrário, seu desejo era ficar e se posicionar.

No escrito, Hamel fez oito perguntas que foram devidamente respondidas por Barth. Em suas respostas, Barth procurou levar o pastor a entender que deveria ser engajado e ter sempre um papel de obediência ao Evangelho. O teólogo afirmou que Deus estava acima do ateísmo e do materialismo que o regime comunista parecia exaltar e que para sair do legalismo do governo a igreja não precisava criar outro legalismo. A igreja vivia sob a graça e não sob a lei e, portanto não deveria responder ao materialismo dialético com uma filosofia cristã ${ }^{162}$. Barth queria produzir um discurso profético que denunciasse qualquer injustiça e qualquer tentativa de amordaçar a liberdade da pregação cristã. O papel da igreja é de pregar o Evangelho como boas novas de Jesus em qualquer que seja o regime político. A Palavra de Deus combina reflexão teológica com a situação vital do ser humano. Deus vê o homem de modo integral.

$\mathrm{Na}$ Alemanha Oriental estava acontecendo algo mais grave que na Hungria: só estava sendo permitido o funcionamento da igreja oficial, ou seja, aquela que estivesse em harmonia com a ideologia do Estado. Diante disso, Barth elaborou a posição de que a igreja sem liberdade não poderia mais ser cristã, e se posicionou enviando uma carta ao ministro alemão solicitando-lhe que recuasse e libertasse os presos que o regime alemão oriental havia feito.

Neste momento de crise política internacional, Barth fez três considerações muito importantes: em primeiro lugar, alertou à igreja que não deveria temer frente a esta situação que ameaçava a paz num tempo de instabilidade. Em segundo lugar, ressaltou que a igreja não deveria colaborar com este conflito e,

${ }^{161}$ CORNU, Daniel. o.c. p. 159.

${ }^{162}$ Ibid, p. 174. 
por fim, que a expressão Leste - Oeste apenas indicava um conflito ideológico e não um conflito entre o bem e o mal ${ }^{163}$.

Diante das denúncias que Barth fez tanto do regime comunista quanto do regime capitalista, pois via defeitos em ambos, o teólogo foi acusado de ser um anarquista. Na década de 70, surgiu uma polêmica tese de doutorado que tentava mostrar que Karl Barth era um teólogo de fortes inclinações anárquicas. Barth conhecia as principais obras anarquistas, assim como conhecia o referencial teórico do socialismo. No pensamento político de Barth encontramos pontos que se assemelham aos postulados anarquistas, mas na prática ele não foi um defensor de tal filosofia.

Barth não era um defensor da revolta que gerava uma nação sem o exercício do poder constituído. Para ele, através do Estado somos conscientizados que temos e nutrimos uma esperança em um mundo onde revolução e ordem são as mesmas coisas ${ }^{164}$. Barth apoiou a tese de que quem se rebela às autoridades se opõe à disposição divina. A verdadeira revolução vem de Deus e não da rebelião dos homens ${ }^{165}$.

É claro que Barth se preocupou e se posicionou com um dos principais assuntos das primeiras décadas da Guerra Fria: a bomba atômica e a tecnologia nuclear. Já em 1945, em virtude do lançamento das bombas em Hiroshima e Nagazaki, Karl Barth definiu a bomba como o horror da invenção nova. Quanto mais a ameaça nuclear se tornava iminente, mais incisivo foi o seu posicionamento. A questão da guerra foi tratada por Barth em sua Dogmática Eclesiástica na parte destinada à proteção da vida. Para ele, a guerra era um problema de todos, que revelava a desordem profunda do ser humano ${ }^{166}$.

As superpotências mundiais (Estados Unidos e União Soviética) argumentavam que precisavam desenvolver o material nuclear como modo de se defenderem das ameaças recíprocas. Para Barth, esse argumento nada mais era que uma ilusão, na realidade, a guerra visava simplesmente à destruição do maior número possível dos indivíduos que constituíam o poder de combate do inimigo $^{167}$.

\footnotetext{
${ }^{163}$ FILHO, Manoel Bernardino de Santana. o.c. p. 100.

${ }^{164}$ Ibid, p. 107.

${ }^{165}$ BARTH, Karl. Carta aos Romanos. 5ed. São Paulo: Fonte Editorial, 2008. p. 746.

${ }^{166}$ CORNU, Daniel. o.c. p. 180.

${ }^{167}$ Idem.
} 
Em 1957, Barth escreveu um artigo especialmente tratando da ameaça nuclear. O texto havia sido solicitado por um jornal de Berlim Ocidental que queria divulgar a sua opinião sobre o assunto. Barth denunciou o perigo terrível da bomba atômica e o das experiências nucleares. Para ele, o perigo atômico era medonho e a distinção entre bombas táticas e estratégicas era ilusória, pois as experiências nucleares por si mesmas constituíam um perigo para a humanidade. O teólogo suíço era taxativamente contrário à proliferação de armas nucleares e convocou a todos, especialmente os cristãos, a se oporem a esse terrível perigo ${ }^{168}$.

Em janeiro de 1959, Barth escreveu uma carta ao Congresso Europeu contra Armas Atômicas, onde afirmou que o verdadeiro remédio contra as ameaças de guerras nucleares era um trabalho positivo em favor da paz e da compreensão. Barth dizia que era imprescindível se esforçar para manter a paz, a fim de servir à vida.

\subsection{2 Karl Barth e o Ecumenismo.}

Nesta última fase da vida de Barth percebe-se o teólogo muito engajado com a causa ecumênica. $O$ Ecumenismo tem muito a ver com engajamento político-social. Primeiro porque uma pessoa engajada na fé em Jesus Cristo, que é uma fé humanizadora, é uma pessoa tolerante, aberta ao diálogo e disposta a superar as diferenças em nome de algo maior que as próprias divergências. Segundo, porque a partir de ações ecumênicas, o engajamento na luta pelos menos favorecidos e por um mundo mais justo se torna mais eficaz e impactante. O próprio Jesus disse em sua oração relatada no Evangelho de João que se os discípulos fossem um, isso testificaria ao mundo que o Pai O enviou ${ }^{169}$.

O Ecumenismo pode ser um poderoso antídoto contra o fundamentalismo e a intolerância tão presentes no cristianismo brasileiro ainda hoje. Barth compreendeu que maior que as divergências doutrinárias que poderiam existir entre os cristãos era a luta político-social que cabia aos discípulos de Jesus e que, em Jesus, podemos desfrutar da experiência de fé que luta por um mundo mais humano e justo.

\footnotetext{
${ }^{168}$ Ibid, p. 186.

${ }^{169}$ Cf. Jo $17 ; 21$.
} 
Numa oportunidade em que Barth se encontrou com o teólogo católico Hans Küng, e lhe perguntou sobre o que existia entre eles. Küng respondeu que entre eles não existia nada, mas por trás de ambos existia muito e os cristãos deveriam lutar por uma reforma que gerasse uma unidade maior da igreja ${ }^{170}$.

O termo Ecumenismo veio da palavra grega oikouméne, que significa literalmente todo o mundo habitado. O movimento ecumênico zela por uma unidade da igreja cristã. O Ecumenismo prega uma unidade entre os cristãos e não uma uniformidade. No movimento todas as igrejas participantes têm a sua liturgia, teologia e formas de governo preservadas. O que se busca não é uma megadenominação, mas esforços em comum de todos os seus integrantes no que diz respeito à fé e ao engajamento político-social.

O Movimento Ecumênico surgiu no mundo protestante. Ainda no século XIX, alguns esforços foram feitos a fim de que cristãos promovessem ações em conjunto. Em 1910, aconteceu a Conferência Missionária Mundial na cidade escocesa de Edimburgo. Esta conferência foi um marco no movimento ecumênico atual, porque nesta reunião o ideal deixou de ser de fusões denominacionais para buscar ações em unidade das diversas igrejas. A Conferência de Edimburgo foi realizada e idealizada pelo metodista norte-americano John Mott (1865 - 1955). A preocupação de Mott era com as tarefas missionárias mundiais, e seu intento era que diferentes igrejas protestantes somassem esforços em prol da obra missionária.

John Mott também foi o presidente da Aliança Mundial das Associações Cristãs de Moços. Seu trabalho missionário e sua preocupação com o ser humano lhe deram o prêmio Nobel da paz em 1946. A Conferência Missionária Mundial de 1910 abriu caminho para outras iniciativas ecumênicas. Outras duas reuniões foram realizadas em Estocolmo (1925) e Oxford (1939). Foi criado também o Conselho Mundial Fé e Ordem, que se reuniu em 1927, na cidade suíça de Lausanne.

O Conselho Mundial Fé e Ordem reuniu cerca de 400 líderes cristãos que representavam 108 igrejas protestantes, ortodoxas e católicos (apenas os que haviam saído da Igreja Católica em virtude da aprovação do dogma da

170 Disponível em www.ihu.unisinos.br/noticias/504575-o-papel-de-leigos-e-leigas. Acessado em 15/10/2013, às 14:54. 
Infalibilidade Papal ${ }^{171}$. Mesmo diante de todo empenho ecumênico, o Papa Pio XI deu um golpe no movimento pelo lado católico ao publicar a encíclica Mortalium Animos em 1928. Na encíclica, o papa afirmou que a única verdadeira igreja era a Igreja Católica e que a maneira de promover uma união entre os cristãos era que os dissidentes (protestantes e ortodoxos) retornassem à única igreja de Cristo $^{172}$.

O Conselho Mundial Fé e Ordem ainda se reuniu novamente em Edimburgo em 1937. Esta segunda reunião abriu caminho para a criação de um Conselho Mundial de Igrejas.

O movimento ecumênico teve grandes nomes em sua primeira fase. Além do metodista John Mott, o arcebispo anglicano de York (posteriormente de Cantuária) William Temple (1881 - 1944), o arcebispo luterano de Uppsala, na Suécia, Nathan Söderblom (1866 - 1931), que recebeu o prêmio Nobel da paz em 1930 por seus esforços pela unidade dos cristãos e da paz universal.

Mesmo com grandes nomes, o Ecumenismo só ganhou a força que precisava com o holandês Williem Visser t'Hooft, que foi o Secretário Geral do Conselho Mundial de Igrejas e liderou a Conferência de Amsterdã em 1948, considerada a mais expressiva e ousada iniciativa do ecumenismo contemporâneo $^{173}$. O Conselho Mundial de Igrejas foi formado a partir das influências do Conselho Missionário Internacional (de John Mott), do Movimento Vida e Obra (de Nathan Söderblom) e do Conselho de Fé e Ordem (de William Temple).

O Conselho Mundial de Igrejas se reuniu em sua primeira sessão no dia 22 de agosto de 1948. Sua formação foi acelerada pela Segunda Guerra Mundial. O protestantismo tentava dar respostas relevantes à sociedade. Houve a participação de 107 igrejas de 47 nações. O sermão de abertura do evento foi feito pelo pastor metodista D. T. Nilles (1908 - 1970), do Ceilão (atual Sri Lanka). Nilles tinha grande experiência como líder do Movimento Cristão Estudantil ${ }^{174}$.

\footnotetext{
${ }^{171}$ GONZALEZ, Justo. Uma História Ilustrada do Cristianismo - A Era Inconclusa. p.110.

172 Disponível em www.vatican.va/holy_father/pius_xi/encyclicals/documents/hf_pxi_enc_19280106_mortalium-animos_po.html. Acessado em 02/01/2014, às 15:21.

${ }^{173}$ SHELLEY, Bruce. História do Cristianismo ao Alcance de Todos. São Paulo: Shedd Publicações, 2004. p. 493.

${ }^{174}$ GONZALEZ, Justo. Uma História Ilustrada do Cristianismo - A Era Inconclusa. p.112.
} 
A sessão de Amsterdã também ouviu oradores como o norte-americano Reinhold Niebuhr (1892 - 1971), o tcheco Joseph Hromádka, o alemão Martin Niemoller entre outros.

Karl Barth não apenas participou da Conferência do CMI de Amsterdã, como foi um dos oradores e o principal elaborador da Confissão Teológica de Fé do encontro. O Conselho de Igrejas convocou todas as denominações presentes a rejeitarem tanto o comunismo quanto o capitalismo liberal e a oporem-se à noção errônea de que esses dois sistemas haviam esgotado todas as alternativas possíveis $^{175}$.

Em seu discurso, Karl Barth lamentou publicamente a ausência de ortodoxos e católicos romanos naquela importante conferência. Barth exerceu muita influência sobre Visser t'Hooft, que o admirava. Barth percebeu que a igreja quase perdeu sua essência ao se ajustar às tendências históricas e a convidou a ser novamente ela mesma. Propôs que a igreja deveria ser igreja sem que isso representasse uma fuga do mundo, apenas que a igreja não era simplesmente um eco das direções do mundo ${ }^{176}$. Barth apresentou a igreja como uma comunidade dos santos em Cristo. Por isso, a igreja devia sua realidade a Jesus Cristo e caminha em direção à sua vocação ${ }^{177}$.

O Conselho Mundial de Igrejas ganhou a adesão dos ortodoxos quando Visser t'Hooft reformulou a confissão de fé inserindo uma clara afirmação trinitária, que era reivindicado pelos ortodoxos. Desta forma, os ortodoxos orientais se tornaram membros ativos do movimento ecumênico. Já do lado católico, o diálogo foi difícil até meados da década de 60. Graças aos esforços do teólogo dominicano Yves Congar e dos avanços oferecidos pelo Papa João XXIII no Concílio Vaticano II, a relação ecumênica com os católicos tornou-se muito melhor. Hoje, os católicos ainda não são membros integrantes do Conselho Mundial de Igrejas, mas participam de todas as suas seções como observadores e estabelecem diálogos em diversas frentes.

${ }^{175}$ Ibid, p.113.

${ }^{176}$ SHELLEY, Bruce. o.c. p. 496.

${ }^{177}$ FILHO, Manoel Bernardino de Santana, Por uma Antropologia Teológica Ecumênica in: ROCHA, Alessandro (org.), Ecumenismo para o Século XXI. São Paulo: Fonte Editorial, 2011. p. 77. 
Depois de Amsterdã em 1948, o Conselho Mundial de Igrejas voltou a se reunir em outras oportunidades. A mais recente aconteceu em 2006, na cidade de Porto Alegre, no Brasil.

O Secretário Geral do Conselho Mundial de Igrejas, Visser't Hooft, representou o órgão numa cerimônia realizada quatro dias depois do falecimento de Karl Barth. Numa cerimônia ecumênica, Hooft expressou a gratidão do Conselho ao serviço pastoral e ecumênico que Barth havia dedicado ao longo de sua vida. Hooft disse que este serviço não era totalmente reconhecido naquele momento da história, mas que seria redescoberto e honrado no futuro por gerações de teólogos, que retomariam seus textos para servir de fonte para lidar com situações históricas concretas ${ }^{178}$.

$\mathrm{Na}$ última década da vida de Barth houve algo que marcou profundamente o cristianismo contemporâneo e consequentemente a teologia e a ecumenicidade. $\mathrm{O}$ Concílio Vaticano II (1962 - 1965) foi um verdadeiro marco histórico que despertou em Barth um apreço ainda maior pela teologia católica.

O último concílio realizado antes do Vaticano II aconteceu em 1869-1870. Foi o Concílio Vaticano I convocado pelo Papa Pio IX. No Vaticano I, o catolicismo ainda não pensava ecumenicamente e a postura do papa em relação aos protestantes e ortodoxos era de considerá-los, respectivamente como hereges e cismáticos, e apelar para que os mesmos se arrependessem e retornassem ao rebanho católico.

Em 1959, antes mesmo do anúncio do Vaticano II, o teólogo Yves Congar levantou a questão do ecumenismo e a relação da Igreja Católica com as outras igrejas. Para Congar era preciso tomar consciência do outro, mas não vê-lo mais como um dissidente, e sim reconhecer realidades espirituais diferentes ${ }^{179}$. A proposta ecumênica era da aceitação de um comum patrimônio cristão.

Meses depois de Congar ter levantado a questão ecumênica, o Papa João XXIII surpreendeu o mundo ao anunciar que convocaria um novo concílio e que não seria simplesmente a continuação do anterior. Já durante os preparativos do Concílio, o Papa João XXIII se mostrou simpático aos não-católicos. Em seu convite, o papa não fala de um retorno, mas de uma cooperação entre as igrejas

${ }^{178}$ Ibid, p. 84 .

179 VELATI, Mauro. Os Outros: Ecumenismo e Religiões in Revista Concilium Vaticano II um Futuro Esquecido? pg. 60 
cristãs. Muitos protestantes e ortodoxos perceberam no convite do Papa João XXIII como uma atitude fraterna, em vez da antiga hostilidade ${ }^{180}$.

Entre o final de 1959 e início de 1960 os não-católicos se manifestaram: o Patriarca ecumênico de Constantinopla Atenágoras, que havia dado pronto retorno à mensagem papal, enviou o seu representante oficial, o metropolita de Malta Iakovos que foi recebido pelo Papa João XXIII. No início de 1960 foi a vez do Secretário Geral do CMI, Visser't Hooft se manifestar expressando um interesse muito particular pelo gesto de João XXIII em favor da unidade dos cristãos ${ }^{181}$. Os anglicanos também demonstraram interesse através do envio de um eclesiástico ao Vaticano, antecedendo a visita do próprio arcebispo de Cantuária a Roma.

O Papa organizou um Secretariado para a Unidade dos Cristãos sob a liderança do Cardeal Augustin Bea (1881 - 1968). Este Secretariado inclusive recebeu a missão do próprio Papa para estudar as questões relacionadas ao antissemitismo $^{182}$. O Cardeal Bea e o seu Secretariado fizeram convites a ortodoxos e protestantes participarem como observadores do Concílio Vaticano II. Era algo sem precedentes na história do cristianismo. Neste momento o catolicismo desistiu oficialmente de sua posição hostil aos não-católicos, e reconheceu que nos processos de 1054 e 1517 houve erros de ambos os lados ${ }^{183}$.

Durante o Concílio Vaticano II, participaram 23 observadores protestantes fora os observadores ortodoxos. Dos 23 destacam-se: 3 anglicanos, 3 luteranos, 3 metodistas, 3 reformados e até um observador quaker. $\mathrm{O}$ observador protestante de maior destaque, sem dúvida, foi o teólogo Oscar Cullmann (1902 - 1999). Cullmann teve papel bastante relevante no Concílio e desfrutava da admiração tanto de João XXIII quanto de Paulo VI por quem foi homenageado em 1966 pelos serviços prestados ao Concílio. O engajamento ecumênico esteve muito presente na vida e obra de Oscar Cullmann, antes, durante e depois do Concílio Vaticano II.

Um dos textos mais relevantes produzidos pelo Vaticano II foi a Constituição Dogmática Lumen Gentium. Em LG 15 as relações entre católicos e não-católicos são tratadas. O texto assinala que os não-católicos são cristãos que

\footnotetext{
${ }^{180}$ ALBERIGO, Giuseppe. o.c. p. 27.

${ }^{181}$ Idem.

182 VELATI, Mauro. Os Outros: Ecumenismo e Religiões in Revista Concilium Vaticano II um Futuro Esquecido? p. 66.

${ }^{183} 1054$ - Cisma entre a igreja ocidental e oriental. 1517 - data da Reforma Protestante.
} 
não guardam a unidade da comunhão sob o sucessor de Pedro, mas admite que os mesmos honram a Sagrada Escritura, tem sincero zelo religioso, creem com amor em Deus e em Cristo. São unidos a Cristo pelo batismo, algumas possuem o episcopado, celebram a Eucaristia e nutrem piedade para com a Virgem ${ }^{184}$, dentre outras características. O texto fala com muita simpatia pelos não-católicos e estimula as relações ecumênicas.

O Concílio Vaticano II ainda produziu o decreto Unitatis Redintegratio de novembro de 1964 sob a liderança de Paulo VI. Neste decreto o Concílio afirmou que um dos seus principais propósitos era promover a restauração da unidade entre todos os cristãos. $\mathrm{O}$ decreto reconheceu a variedade de comunhões cristãs $\mathrm{e}$ convoca os fiéis católicos a participarem dos trabalhos ecumênicos ${ }^{185}$.

Karl Barth foi convidado para ser um dos observadores oficiais do Concílio Vaticano II, o que infelizmente não se concretizou porque exatamente neste período, Barth passou por uma fase bem complicada para a sua saúde, impossibilitando-o de participar do Concílio. Teria sido muito bom se Barth estivesse presente, com certeza sua contribuição teria sido marcante.

O fato de não ter podido participar do Vaticano II não impediu Barth de desenvolver relações ecumênicas com o catolicismo, e nem de se interessar pela teologia produzida no Concílio. Como alguém que era atento aos fatos de seu contexto, Barth seguiu passo a passo o que estava acontecendo no Vaticano.

Em 1963, Barth publicou um artigo numa revista ecumênica baseando-se nas cartas que havia trocado com Visser't Hooft, com o Cardeal Bea e com o próprio Papa Paulo VI. Barth, que na assembleia do Conselho Mundial de Igrejas de 1948 havia publicamente lamentado a ausência dos romanos no encontro, viu no Vaticano II um sopro do Espírito sobre a igreja. O evento exerceu grande fascínio no pensamento do teólogo, especialmente os textos do Concílio que tratava do engajamento político-social e das questões de justiça social e pobreza.

Em 1966, com o Concílio já encerrado e com a saúde em melhor situação, Barth fez uma visita ao Vaticano acompanhado de sua esposa, Nelly Barth e de seu médico particular, que por sinal era católico. Na visita, Barth se encontrou e discutiu assuntos teológicos relevantes com Karl Rahner (1904 - 1984) e Joseph

184 VIER, Frederico (Org.). Compêndio do Vaticano II, constituições, decretos, declarações. 29ed. Petrópolis: Editora Vozes, 2000. p. 56.

${ }_{185}$ Disponível em www.vatican.va/archive/hist_councils/il_vatican_council/documents/vatil_decree_19641121_unitatis-redintegratio_po.html. Acessado em 02/01/2014, às 15:34. 
Ratzinger (Papa emérito Bento XVI). O encontro mais importante desta viagem foi com o Papa Paulo VI em 26 de setembro de 1966. Na conversa, ambos trataram sobre o papel de Maria na igreja, sobre o ecumenismo e a substituição do termo herege por irmãos separados, termo este inserido pelo Vaticano II.

No encontro Barth demonstrou que queria mais do que irmãos separados embora já fosse um grande avanço. Barth e Paulo VI trocaram presentes e nos textos que Barth deu ao Papa estava a dedicatória: Do irmão separado Karl Barth no comum serviço do único Senhor...ao Bispo Paulo VI humilíssimo servo de Deus""186. Em 1967, Barth mandou uma carta de felicitações ao Papa pelo aniversário de 70 anos. Pouco depois o Papa respondeu a Barth chamando-o de um estimadíssimo professor que buscava corajosamente a verdade e que trazia muito em seu coração o pensamento da comunhão fraterna em Cristo ${ }^{187}$.

Ao final de sua vida Barth participava em um domingo da celebração católica e noutro da liturgia protestante em sua cidade. Celebrou com alegria os avanços do Vaticano II em busca da unidade dos cristãos em todo o mundo ${ }^{188}$.

Karl Barth na última fase de sua vida (1945 - 1968) trabalhou dedicadamente pela causa ecumênica. Creu, num momento em que o mundo estava incrédulo, por causa das consequências da Segunda Guerra, que os cristãos deveriam deixar de lado suas diferenças doutrinárias e reforçar a unidade da experiência da fé, para que pudessem ter discurso e prática relevantes para o mundo pós-guerra. Barth respondeu à incredulidade europeia gerada pela guerra com a apresentação do Deus humilde e sofredor, que não impedia o mal, mas que estava presente quando este acontecia.

Para Barth o ecumenismo era parte do engajamento político-social, não apenas porque promoveria ações conjuntas mais impactantes na sociedade, como também daria ao mundo o exemplo de unidade e fraternidade entre os cristãos, e esse exemplo seria muito relevante.

Barth acreditava que a igreja deveria viver uma vida de humildade e serviço. O sinal da vida da igreja é o serviço e não a dominação. Além disso, para ele a igreja universal só se compreende na igreja local e na sua realização concreta.

\footnotetext{
${ }^{186}$ Disponível em www.ihu.unisinos.br/noticias-anteriores/17003-quando-karl-barth-fez-oexame-no-concilio. Acessado em 28/10/2013, às 10:32.

${ }^{187}$ Idem.

${ }^{188}$ FILHO, Manoel Bernardino de Santana, Por uma Antropologia Teológica Ecumênica in: ROCHA, Alessandro (org.). o.c. p. 83.
} 
Sem a comunidade que se reúne e adora, não existe a instituição chamada igreja $^{189}$.

Barth valorizou muito a questão ecumênica. Para ele não havia dúvidas de que, enquanto a cristandade fosse formada por igrejas diferentes que se opunha mutuamente, ela estaria negando na prática o que confessava teologicamente: a unidade e a singularidade de Deus, de Jesus Cristo e do Espírito Santo ${ }^{190}$. Para ele, uma das principais características da igreja deveria ser a inclusividade.

${ }^{189} \mathrm{Ibid}, \mathrm{p} .78$.

${ }^{190}$ Ibid, p. 67. 


\section{5 \\ Conclusão}

Ao longo desta dissertação o autor procurou analisar o engajamento político-social como consequência da fé e da teologia na vida de Karl Barth.

No contexto protestante brasileiro ainda predomina uma visão dualista de mundo, onde se faz separação entre o santo e o profano, entre as coisas de Deus e do mundo, entre santos e ímpios, entre espiritualidade e cultura, etc. Além disso, vemos algumas das chamadas lideranças evangélicas do país absolutamente comprometidas com um sistema político-social capitalista e opressor.

Para que se desenvolva um engajamento político-social sério na igreja protestante brasileira é necessário superar a visão dualista de mundo, para que uma teologia holística seja abraçada, uma teologia que veja o ser humano em sua integralidade. Também será necessário um comprometimento ético com a fé cristã, e uma vida engajada com os princípios de Reino de Deus estabelecidos por Jesus. A igreja, de um modo geral, precisa ser mais cristã em seus discursos e práticas. Para Jesus, o homem prudente é aquele que primeiramente ouve as suas palavras, adquire conhecimento de sua vontade e simultaneamente as pratica, ou seja, transforma em vida o conhecimento intelectual. Este, na fala de Jesus, é um sábio $^{191}$.

Jesus espera que os seus discípulos tenham uma postura engajada holisticamente, que tenham fome e sede de justiça, porque por causa da injustiça muitos têm fome e sede literalmente. Jesus espera que seus discípulos sejam vozes proféticas em seu tempo a denunciar o erro e a lutar por aqueles a quem Ele amou.

Diante de tudo isso, o teólogo suíço Karl Barth tem muito a nos dizer. Usando a linguagem neotestamentária, Barth não apenas ouviu as palavras de Jesus como as colocou em prática e deixou-se guiar por elas.

Barth entendeu que um encontro com Jesus não nos diviniza e nos torna superiores, pelo contrário, nos humaniza e nos torna corresponsáveis. Sua teologia não foi feita em laboratório ou no gabinete, foi feita na vida. Barth fazia questão de que sua teologia fosse encarnada com a vida real de pessoas reais, por isso mudou o nome de sua obra-prima, que inicialmente se chamava Dogmática Cristã e depois passou a se chamar Dogmática Eclesiástica, por constatar que a teologia

${ }^{191}$ Cf. Mt 7;24. 
era produzida não pelos grandes intelectuais, mas pelo povo de Deus, pela comunidade de fé.

Para Barth, a teologia era produto da fé. A fé provocava engajamento e o engajamento era estimulado pela própria teologia. Para ele, comprometer-se com Deus era comprometer-se com o próximo, com aquele que foi amado por Deus e por quem Deus se entregou.

Não foi fácil para Barth conviver com as consequências de sua fé, afinal ele viveu nada menos que as duas mais destrutivas guerras da humanidade (a Primeira e a Segunda Guerras Mundiais) e pela mais ameaçadora tensão mundial (a Guerra Fria), e sempre manteve sua posição ainda que isso o prejudicasse pessoalmente.

Em Safenwil, Barth não se omitiu diante do quadro de exploração estabelecido na cidade. Uma das famílias mais poderosas da região era da igreja de Barth. Um deles era membro do conselho eclesiástico da igreja de Safenwil. Talvez tivesse sido mais conveniente para ele se calar, mas ele não fez isso. Barth optou por ficar do lado dos mais pobres e dos explorados, e usou todos os recursos de que dispunha para lutar pelos oprimidos da cidade, desde o púlpito de sua igreja até as ruas. Barth não teve pudor em descer do púlpito e ir para as ruas e sindicatos cuja criação incentivou. Tudo isso rendeu a Barth problemas com os ricos de Safenwil e com sua própria denominação.

Como professor, Barth sempre fez questão de ensinar aos seus alunos a relacionar o conteúdo de fé com a realidade vivida pelas pessoas, e a estarem sempre conscientes da realidade vigente em seus respectivos contextos. $\mathrm{Na}$ Alemanha lutou contra a nazificação do cristianismo alemão e contra um Estadodeus que considerou ilegítimo justamente por promover a exclusão e a exploração. Rejeitou-se a prestar juramento de obediência a um líder de um Estado totalitário, e foi uma das mais audíveis vozes de resistência, sendo um dos principais articuladores da Igreja Confessante e da Declaração de Fé de Barmen. Foi proibido de ensinar, pregar ou publicar na Alemanha e ainda foi aposentado compulsoriamente pelo regime nazista. Com isso teve de retornar para a Suíça.

Com o fim da Segunda Guerra também se preocupou com a reconstrução da Alemanha. E durante sua última fase de vida rompeu as barreiras entre igrejas, e abraçou o diálogo e a tolerância entre as mais diferentes tradições cristãs.

É claro que Barth era suíço e estava inserido em seu contexto políticosocial-eclesiástico europeu, mas ainda assim ele tem muito a contribuir e nos dizer 
em nosso contexto latinoamericano. Muito do que foi pregado pela Teologia da Libertação e da Missão Integral já estavam presentes em Barth décadas antes. Seu engajamento pode servir de modelo para a nossa realidade e nos inspirar em muito.

Como teólogo Barth não se limitou ao discurso intelectual, mas a dar respostas relevantes para a vida humana real e concreta. Propôs-se a responder as perguntas existenciais mais relevantes de seu tempo tanto diante das consequências progressistas da Primeira Guerra, quanto no desapontamento de fé ao fim da Segunda Guerra Mundial.

O ser humano clama por justiça e igualdade. A Primavera Árabe nos mostrou isso. As Manifestações no Brasil mostraram isso. Diante desse clamor, a igreja cristã deve ter uma resposta para as questões mais relevantes da humanidade, e Barth nos inspira a irmos em busca dessas respostas. 


\section{Referências Bibliográficas}

\section{OBRAS DE KARL BARTH}

BARTH, Karl. Carta aos Romanos. 5ed. São Paulo-SP: Fonte Editorial, 2008. $854 p$.

$69 \mathrm{p}$.

. Chamado ao Discipulado. São Paulo-SP: Fonte Editorial, 2006.

Credo - Comentários ao Credo Apostólico. São Paulo-SP: Fonte Editorial, 2005. 254p.

. Esboço de uma Dogmática. São Paulo-SP: Fonte Editorial, 2006.

$224 p$.

Fé em Busca de Compreensão. 3ed. São Paulo-SP: Fonte

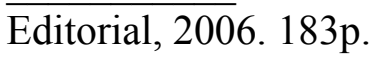

Palavra de Deus e Palavra do Homem. São Paulo-SP: Fonte Editorial, 2004. 247p.

. Revelação de Deus como Sublimação da Religião. São Paulo-SP: Fonte Editorial, 2011. 152p.

Sinodal, 2013. 72p.

Senhor! Ouve a Nossa Oração! São Leopoldo-RS: Editora

O Pai Nosso - a Oração que Jesus Ensinou aos Discípulos. São

Paulo-SP: Editora Novo Século, 2003. 72p.

\section{DEMAIS OBRAS}

ALBERIGO, Giuseppe. Breve História do Concílio Vaticano II. Aparecida-SP: Editora Santuário, 2006. 222p.

ALTMANN, Walter (Ed.). Karl Barth - Dádiva e Louvor; Artigos Selecionados. 2ed. São Leopoldo-RS: Editora Sinodal, 1996. 432p.

AQUINO, Rubim; ALVARENGA, Francisco; FRANCO, Denize; LOPES Oscar. História das Sociedades - das Sociedades Modernas às Sociedades Atuais. 35ed. Rio de Janeiro-RJ: Editora Ao Livro Técnico, 1995. 429p.

BLAINEY, Geoffrey. Uma Breve História do Século XX. São Paulo-SP: Editora Fundamento Educacional, 2009. 309p.

CAIRNS, Earle E. O Cristianismo Através dos Séculos - Uma História da Igreja Cristã. 2ed. São Paulo-SP: Editora Vida Nova, 1995. 508p. 
CORNU, Daniel. Karl Barth Teólogo da Liberdade. Rio de Janeiro-RJ: Editora Paz e Terra, 1971. 201p.

FILHO, Manoel Bernardino de Santana. Palavra-Evento e Práxis Libertadora. A Eclesiologia de Karl Barth e sua Contribuição para a Teologia Latinoamericana. Tese Doutoral. PUC-Rio. 2012. 368p.

GIBELlinI, Rosino. A Teologia do Século XX. 2ed. São Paulo-SP: Edições Loyola, 2002. 591p.

GONZALEZ, Justo L. Uma História Ilustrada do Cristianismo, vol.9 - A Era dos Novos Horizontes. São Paulo-SP: Editora Vida Nova, 1998. 212p.

Uma História Ilustrada do Cristianismo, vol.10 - A Era Inconclusa. São Paulo-SP: Editora Vida Nova, 1998. 142p.

HOBSBAWM, Eric. A Era dos Impérios 1875 - 1914. 13ed. São Paulo-SP: Editora Paz e Terra, 2011. 583p.

Era dos Extremos, o Breve Século XX 1914 - 1991. 2ed. São Paulo-SP: Editora Companhia das Letras, 2012. 598p.

HORDERN, William E. Teologia Contemporânea. São Paulo-SP: Editora Hagnos, 2003. 319p.

KÜNG, Hans. A Igreja tem Salvação? São Paulo-SP: Editora Paulus, 2012. 293p.

LUTZER, Erwin. A Cruz de Hitler. São Paulo-SP: Editora Vida, 2003. 259p.

MACKINTOSH, Hugh R. Teologia Moderna de Schleiermacher a Bultmann. São Paulo-SP: Fonte Editorial, 2002. 384p.

MCBRIEN, Richard P. Os Papas - Os Pontífices de São Pedro a João Paulo II. 3ed. São Paulo-SP: Edições Loyola, 2013. 528p.

MELLONI, Alberto e THEOBALD, Christoph (org.). Revista Concilium Vaticano II: Um Futuro Esquecido? Petrópolis-RJ: Editora Vozes, 2003. 192p.

MONDIN, Battista. Os Grandes Teólogos do Século XX. São Paulo-SP: Editora Teológica, 2003. 768p.

NASCIMENTO, André dos Santos Falcão. Nazismo e Cristianismo - a Relação entre a Igreja Protestante Alemã e o Movimento Nacional-Socialista. São Paulo-SP: Fonte Editorial, 2012. 106p.

PASSELECQ, Georges e SUCHECKY, Bernard. A Encíclica Escondida de Pio XI. Petrópolis-RJ: Editora Vozes, 1998. 396p. 
ROCHA, Alessandro (org.). Ecumenismo para o Século XXI. São Paulo-SP: Fonte Editorial, 2011. 174p.

SHELLEY, Bruce. História do Cristianismo ao Alcance de Todos. São PauloSP: Shedd Publicações, 2004. 572p.

VIER, Frederico (Ed.). Compêndio do Vaticano II. 29ed. Petrópolis-RJ: Editora Vozes, 2000. 743p. 